\title{
\#USGS
}

Prepared in Cooperation with Oregon Department of Geology and Mineral Industries and Washington Geological Survey

\section{Geologic Map of the Greater Portland Metropolitan Area and Surrounding Region, Oregon and Washington}

By Ray E. Wells, Ralph A. Haugerud, Alan R. Niem, Wendy A. Niem, Lina Ma, Russell C. Evarts, James E. O'Connor, Ian P. Madin, David R. Sherrod, Marvin H. Beeson, Terry L. Tolan, Karen L. Wheeler, William B. Hanson, and Michael G. Sawlan

Scientific Investigations Map 3443

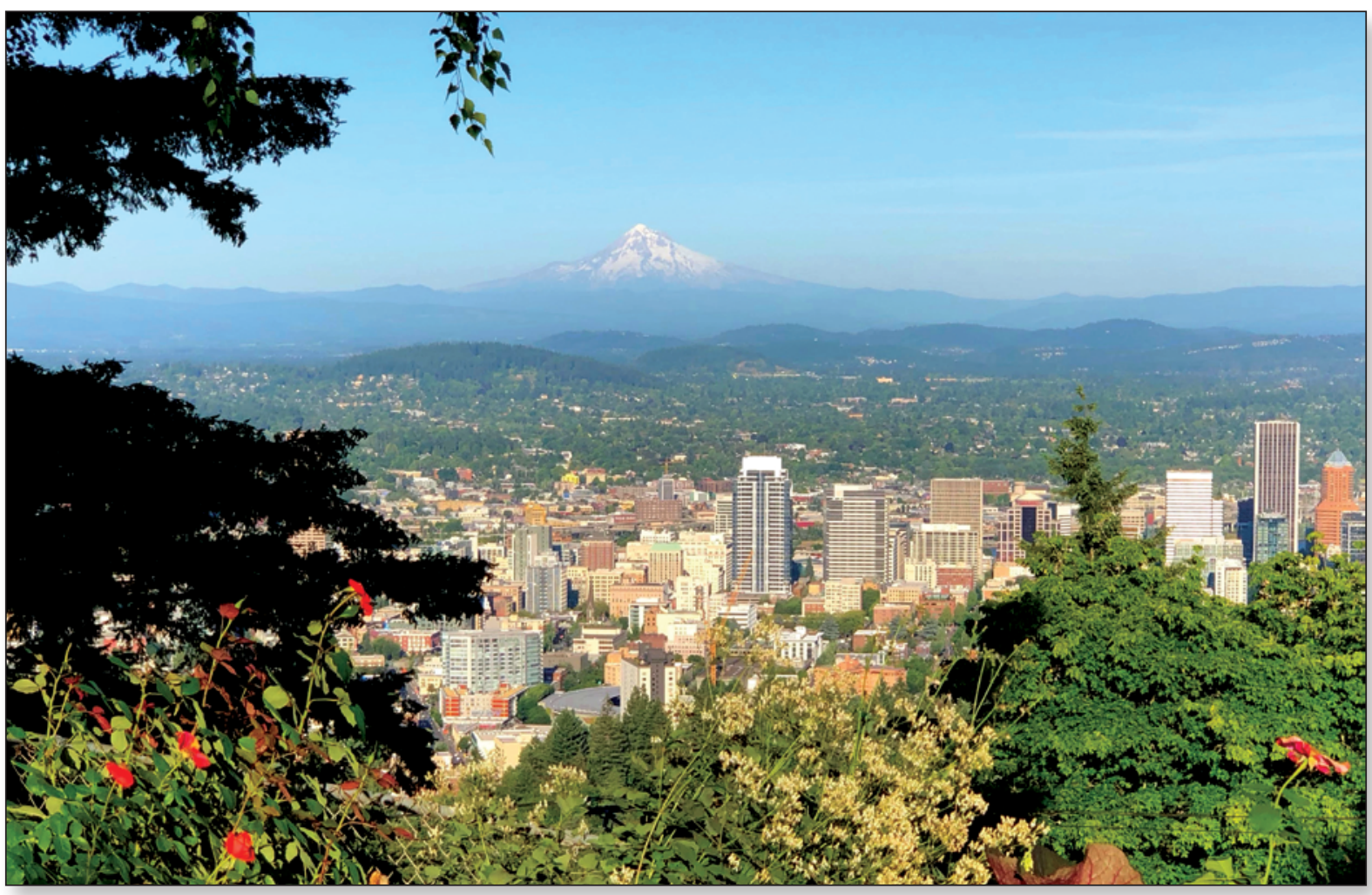




\title{
U.S. Department of the Interior DAVID BERNHARDT, Secretary
}

\author{
U.S. Geological Survey \\ James F. Reilly II, Director
}

U.S. Geological Survey, Reston, Virginia: 2020

For more information on the USGS - the Federal source for science about the Earth, its natural and living resources, natural hazards, and the environment—visit https://www.usgs.gov or call 1-888-ASK-USGS.

For an overview of USGS information products, including maps, imagery, and publications,

visit https://store.usgs.gov.

Any use of trade, firm, or product names is for descriptive purposes only and does not imply endorsement by the U.S. Government.

Although this information product, for the most part, is in the public domain, it also may contain copyrighted materials as noted in the text. Permission to reproduce copyrighted items must be secured from the copyright owner.

Suggested citation:

Wells, R.E., Haugerud, R.A., Niem, A.R., Niem, W.A., Ma, L., Evarts, R.C., O'Connor, J.E., Madin, I.P., Sherrod, D.R., Beeson, M.H., Tolan, T.L., Wheeler, K.L., Hanson, W.B., and Sawlan, M.G., 2020, Geologic map of the greater Portland metropolitan area and surrounding region, Oregon and Washington: U.S. Geological Survey Scientific Investigations Map 3443, pamphlet 55 p., 2 sheets, scale 1:63,360, https://doi.org/10.3133/sim3443.

ISSN 2329-132X (online)

Cover. Photograph of Downtown Portland, Oregon, looking east from the Pittock Mansion in the West Hills, Tualatin Mountains, toward Mount Hood, an active stratovolcano ( 11,249' high) on the skyline, about $50 \mathrm{mi}(80 \mathrm{~km})$ from Portland. Most of the low hills in the middle distance are Pleistocene volcanoes of the Boring Volcanic Field, which lie within the city limits. They range in age from 200,000 to 1 m.y. old. 


\section{Contents}

Introduction

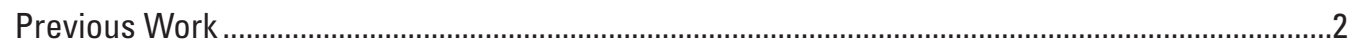

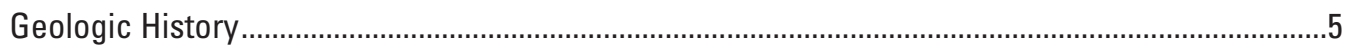

Accretion of Siletzia and Creation of the Cascadia Subduction Zone (56-44 Ma) ...................5

Fore-arc Rifting and Magmatism (42-34 Ma).................................................................

Early Cascade Volcanic Arc Activity and Filling of the Fore-arc Basin (40-16 Ma) .................8

Flood Basalt Eruptions of the Columbia River Basalt Group (17-15 Ma)..............................10

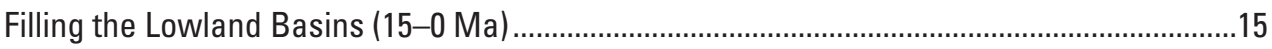

Basaltic Eruptions of the Boring Volcanic Field (2.7-0.1 Ma) ..............................................16

Glaciation, Volcanic Eruptions, and Cataclysmic Floods (800-12 ka) ...................................17

The Modern Landscape (14 ka-present) ......................................................................19

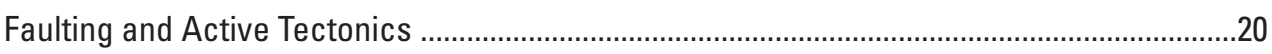

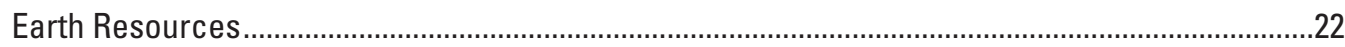

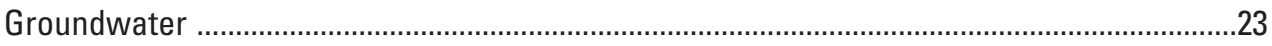

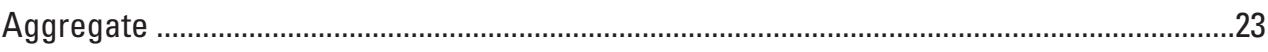

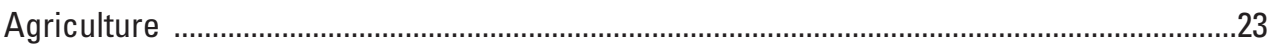

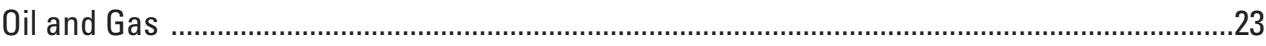

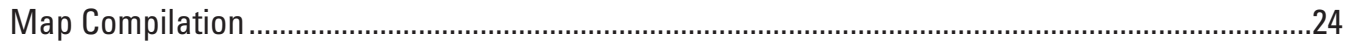

Process Steps

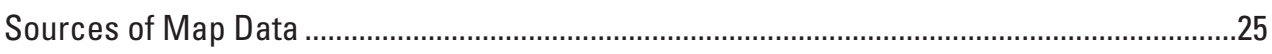

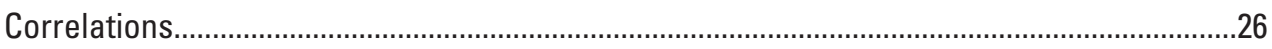

Acknowledgments

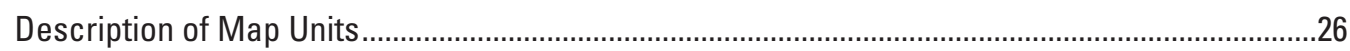

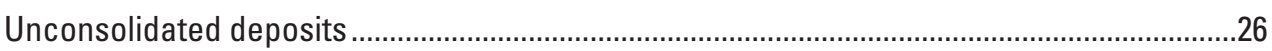

Sedimentary and Volcanic Fill of the Portland, Tualatin, and northern Willamette basins ....30

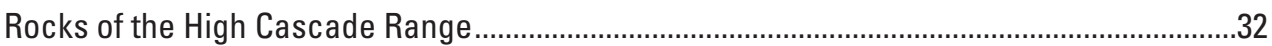

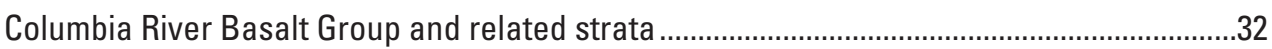

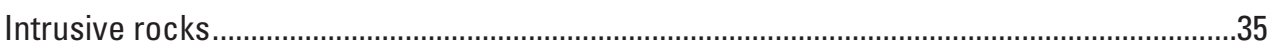

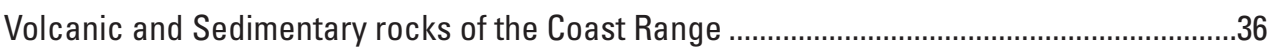

Younger rocks of the Western Cascade Range .......................................................................40

Older rocks of the Western Cascade Range ..........................................................................

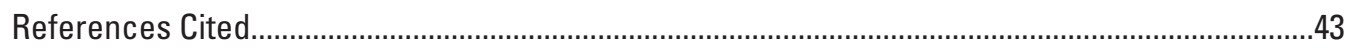

\section{Figures}

1. Maps showing $(A)$ locations and names for quadrangles and counties and $(B)$ sources of geologic mapping in the greater Portland metropolitan area and surrounding region.....sheet 2

2. Map showing geologic setting of the greater Portland metropolitan area and surrounding

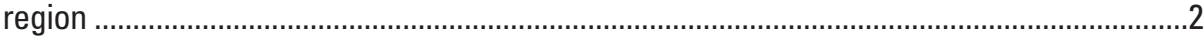

3. Map showing location of geologic map and geographic locations discussed in the text......4

4. A. Photograph of subaerial basalt flows overlain by ash-flow tuff in the Siletz River Volcanics (Tsra) in quarry on Carpenter Creek. B. Photograph of submarine pillow basalt unit of the Siletz River Volcanics (Tsrm), along the Trask River.

5. Cartoon showing a basaltic oceanic island chain similar to Hawaii colliding with the North America margin at about 50 million years ago

6. Photograph of Yamhill Formation (Ty) mudstone near Yamhill, Oregon .................................7

7. A. Photograph of columnar jointed diabase (Tis) in Gales Creek, Oregon. B. Photograph of hand sample of coarse-grained diabase composed dominantly of plagioclase and pyroxene 
8. Photograph of columnar jointed to blocky, vesicular basalt of the Eocene basalt of Waverly Heights along the Willamette River, about $10 \mathrm{~km}$ south of Portland.

9. Photograph of bedded micaceous sandstone of the Cowlitz Formation (Tc) at Scoggins

Dam, $6 \mathrm{~km}$ southwest of Forest Grove, Oregon

10. Photograph of tuffaceous mudstone of the Keasey Formation (Tk), Highway 26, Oregon ....9

11. A. Photograph of basaltic sandstone of the basal Stimson Mill member of the Keasey Formation (Tksm) along Scoggins Valley Road, about $1 \mathrm{~km}$ east of Scoggins Dam.

$B$. Photograph of fossil shell bed in sandstone

12. Photograph of fine-grained, cross-laminated, micaceous sandstone of the Scappoose Formation on Ribbon Ridge (Tsrs), about 10 km northwest of Newberg, Oregon..............10

13. Map of Columbia River Basalt Group (CRBG) in western Oregon and Washington ........11

14. Columbia River Basalt Group stratigraphic chart ........................................................12

15. A. Graph of $\mathrm{TiO}_{2}$ versus $\mathrm{Cr} / \mathrm{P}_{2} \mathrm{O}_{5}$ for selected formations in the Columbia River Basalt Group. B. Graph of $\mathrm{MgO}$ versus $\mathrm{TiO}_{2}$ percentage for Grande Ronde Basalt geochemistry samples...

16. Photograph of thick, red-orange soil of the Jory series typically developed on flows of the Columbia River Basalt Group in western Oregon.

17. A. Photograph of Wapshilla Ridge member of the Grande Ronde Basalt of the Columbia River Basalt Group (Tgwr) in a quarry about $2 \mathrm{~km}$ south of Laurelwood. $B$. Hand sample of Wapshilla Ridge member showing characteristic, abundant microphenocrysts of plagioclase 1-2 mm long.

18. A. Photograph of the Frenchman Springs Member of the Wanapum Basalt on Interstate 205 near West Linn, Oregon. B. Hand sample showing presence of abundant megacrysts of plagioclase feldspar up to $2 \mathrm{~cm}$ across that characterize the flows of Ginkgo, a subunit in the Frenchman Springs Member. C. Hand sample showing plagioclase megacrysts in the flows of Ginkgo that can exceed $2.5 \mathrm{~cm}$ diameter.....

19. Photograph of fluvial cobble gravel of Columbia River source (QTcr), exposed along the railroad tracks west of Ridgefield, Washington

20. Photograph of approximately 0.7 -m.y.-old columnar jointed basaltic andesite flow of the Quaternary Boring Volcanic Field (QTb4) at Prune Hill, Washington, along Highway 14 ....16

21. A. Photograph of large boulders as much as $2 \mathrm{~m}$ across in a coarse-grained fan delta (Qfc) deposited by Missoula flood waters exiting the Columbia Gorge at Troutdale. $B$. Photograph of more than 25 rhythmically bedded, fine sand and silt beds of the Missoula flood deposits (Qf) temporarily exposed in a road cut on Highway 26 at Cornell Road ......18

22. Photograph of windblown gray loess (QI) overlying deep red lateritic paleosol developed on weathered basalt flow of the Winter Water Member of the Columbia River Basalt Group.

23. Photograph of horizontally bedded sand and mudstone of Holocene Willamette River alluvium $(\mathrm{Qa})$ exposed in construction excavation about $13 \mathrm{~m}$ deep in the South Waterfront district of Portland.

24. Photograph of tree stumps along the Sandy River at Camp Angelos that were buried by runout lahars of the 1790 eruption of Mount Hood (Qh3).

25. A. Lidar image of a large landslide of Grande Ronde Basalt of the Columbia River Basalt Group on the north flank of Wildcat Mountain about $5 \mathrm{~km}$ east of Glenwood, Oregon. $B$. Photograph looking south along axis of former divide at lateral scarp cutting across and offsetting ridge crest.

\section{Tables}

1. Sources of map data in SIM3443.gdb, Tualatin.gdb, and OtherSources.gdb ....................52

2. Summary of luminescence age determinations, Portland area, Oregon and Washington.....54

3. Chemical analyses of volcanic and intrusive rocks of the Columbia River Basalt Group and other map units, greater Portland metropolitan area and surrounding region, Oregon and Washington ..https://doi.org/10.3133/sim3443 


\title{
Geologic Map of the Greater Portland Metropolitan Area and Surrounding Region, Oregon and Washington
}

\author{
By Ray E. Wells', Ralph A. Haugerud', Alan R. Niem², Wendy A. Niem², Lina Ma33, Russell C. Evarts', James E. \\ O'Connor ${ }^{1}$, Ian P. Madin ${ }^{3}$, David R. Sherrod' ${ }^{1}$, Marvin H. Beeson ${ }^{4}$, Terry L. Tolan ${ }^{5}$, Karen L. Wheeler ${ }^{1}$, William B. \\ Hanson $^{6}$, and Michael G. Sawlan'
}

\section{Introduction}

This geologic map encompasses the greater Portland metropolitan area (the metro area), an urbanized region astride the confluence of the Willamette and Columbia Rivers in Oregon and Washington. The metro area includes the Portland-VancouverHillsboro metropolitan area, defined by the U.S. Census as the 23rd largest such area in the U.S., having a population of more than 2.2 million people (https://www.census.gov/dataviz/visualizations/026/508.php). The map area extends beyond the urbanized core to include outlying towns and cities and the bounding fault zones that separate the metro area from the adjacent Coast Range and Cascade Range (or Cascades; figs. 1, 2, and 3). The metro area is an area of great scenic, natural, and cultural resources and is the major economic hub of Oregon, containing nearly half of the state's population and generating 75 percent of its gross domestic product (http://oregoneconomicanalysis.com).

The metro area lies within the Coastal Lowland (Haugerud, 2004), a populated lowland that lies between the Coast Range and the Cascade Volcanic Arc. It is subject to a variety of geologic hazards owing to its location above the Cascadia Subduction Zone, where the oceanic Juan de Fuca plate thrusts beneath North America (fig. 2). Underthrusting of the oceanic plate along the Cascadia plate-boundary fault, or megathrust, deforms the leading edge of North America and produces earthquakes on the megathrust and in the overlying plate. Rising magma from the deeper parts of the subduction zone produces active volcanoes that form the Cascade Volcanic Arc, including Mount Hood and Mount St. Helens that are visible from Portland. Both volcanism and strong ground shaking from earthquakes have impacted the metro area, most recently in the 1980 eruptions of Mount St. Helens (Lipman and Mullineaux, 1981) and the 1993 magnitude (M) 5.7 Scotts

\footnotetext{
'U.S. Geological Survey

${ }^{2}$ Oregon State University

${ }^{3}$ Oregon Department of Geology and Mineral Industries

${ }^{4}$ Portland State University

${ }^{5}$ Intera Geoscience and Engineering Solutions

${ }^{6}$ Private consultant
}

Mills, Oregon, earthquake (Madin and others, 1993; Thomas and others, 1996). Great offshore earthquakes as large as M 9 on the Cascadia Megathrust have shaken the metro area every 500 years or so, most recently in 1700 (Atwater and others, 2015). The intensity and duration of shaking during great earthquakes likely varies from place to place, depending on the nature of underlying geologic materials (Mabey and others, 1997; Ma and others, 2012). Giant floods have periodically inundated the metro area, from the cataclysmic ice-age Missoula floods about 20,000-15,000 years ago (age in calendar years; Glenn, 1965; Allison, 1978; O’Connor and others, 2001; O'Connor and Benito, 2009), to the flood generated by collapse of the Bridge of the Gods landslide dam on the Columbia River around C.E. 1421-1447 (O'Connor, 2004; Reynolds and others, 2015).

The metro area includes economically significant infrastructure that depends on its geologic setting. The southern part of the Mist Natural Gas Storage Field occupies the northwest corner of the map (Niem and others, 1994). Important water infrastructure includes the Columbia South Shore Well Field aquifer in the Portland Basin (Hoffstetter, 1984), the Columbia River Basalt aquifer of the Tualatin Basin, and the Tualatin Basin Aquifer Storage and Recovery projects (Burt and others, 2009). The area also includes the proposed site of reconstruction of the Scoggins water supply dam southwest of Forest Grove, several well-known American Viticultural Areas (AVAs) in the western part of the map area (Wells, 2006; Wells and others, 2018), and numerous transportation, transmission, and pipeline corridors (Barnett and others, 2009), including Bonneville Power Administration electrical transmission lines, natural gas pipelines, freeways, and the TriMet Light Rail system and tunnel (Walsh and others, 2011).

We created this map to provide a uniform, modern geologic database for the metro area to better understand its tectonic setting, active faults, volcanoes, landslide hazards, and the distribution of 
geologic materials and resources. Information in this database will be used to improve seismic hazard (Petersen and others, 2015) and resource assessments in this economically important region.

The map is a compilation of new geologic mapping since 1989, supported by the U.S. Geological Survey (USGS) National Cooperative Mapping Program and National Earthquake Hazard Program in a cooperative effort with the Oregon Department of Geology and Mineral Industries (DOGAMI) and Washington Geological Survey (WGS). It consists of 51 quadrangles originally mapped at 1:24,000 scale, including 19 previously unpublished quadrangles in the west half of the map area (see fig. 1, sheet 2). We follow the timescale of Gradstein and others (2012) to assign geologic ages of units. Sources of geologic mapping are in table 1, and luminescence ages of surficial deposits are in table 2. Chemical analyses, largely of Columbia River Basalt Group, that have not previously been published are included in table 3 (separate file at https://doi.org/10.3133/sim3443).

Geologic exposures are sparse in much of the map area as a result of deep weathering, vegetation, and urban development. Windblown, glacially derived silt (loess) mantles much of the terrain south and west of the Columbia River. Most contacts are extrapolated on the basis of topography from limited surface observations and water and natural gas exploration well data. Although geologic mapping was largely completed prior to acquisition of high resolution lidar topography for the region (https://www. oregongeology.org/lidar/collectinglidar.htm), 13 of the quadrangles have been mapped or remapped on lidar bases. In addition, Ma and others (2012) have compiled a surficial deposits map and subsurface database for the central Urban Growth Boundary area in Oregon based on the lidar topography, and their report underlies our representation of the southeastern part of the metro area. DOGAMI has compiled and maintains the state landslide database, which includes the metro area, and is derived from lidar topography (for example, Burns and others, 2012; https://www.oregongeology. org/slido/index.htm). The surficial deposits of the Columbia River floodplain have been mapped in detail on lidar as well (Simenstad and others, 2011; Cannon and others, 2012). Cartographic and topologic errors in the original source maps have been corrected in this compilation, and the geology of the TriMet Light Rail tunnel through the Tualatin Mountains (Walsh and others, 2011) was used to revise the geologic mapping at the surface. Although the database retains nearly all of the geologic detail of 1:24,000-scale maps, the $800+$ units on the original maps have been correlated and grouped into 117 units for this map. Unit descriptions are from original sources, modified to include new data and regional variations of the units. Small polygons representing isolated surficial deposits have been removed from the compiled map. These polygons, largely derived from mapping on lidar bases at a scale of 1:12,000 or larger, are retained in the source maps (see note on database in surficial deposits synthesis of Ma and others, 2012).

\section{Previous Work}

The Portland metropolitan map area extends from the Coast Range on the west, across the lowlands of the Tualatin, Northern Willamette, and Portland Basins, to the Cascade Range

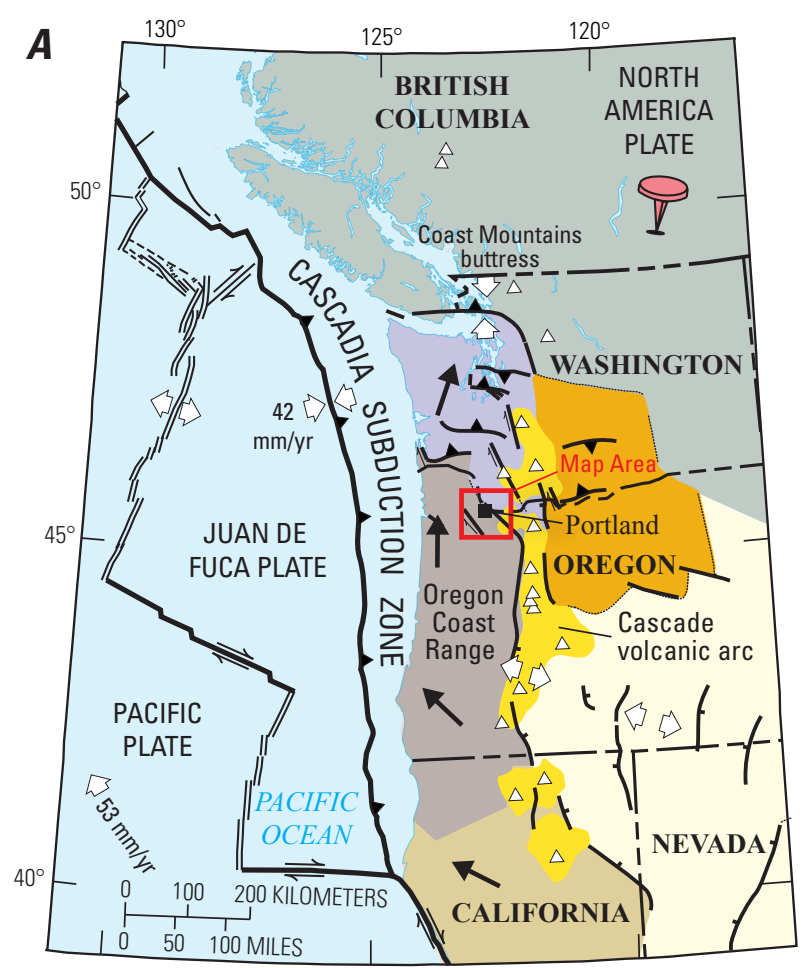

EXPLANATION

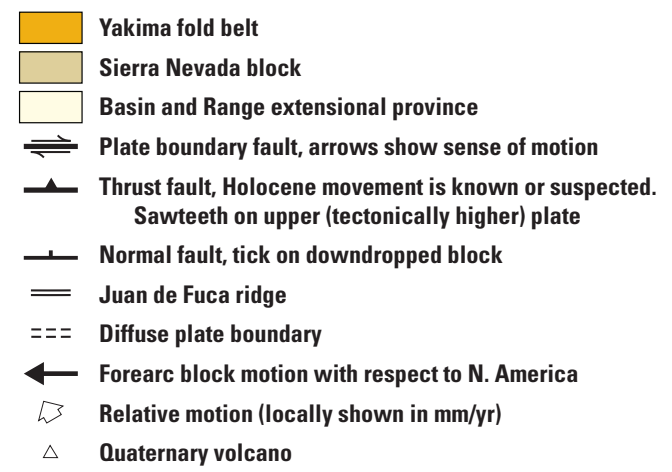

Figure 2. Map showing geologic setting of the greater Portland metropolitan area and surrounding region. $A$. Tectonic setting of study area (red box) in the fore-arc region of the Cascadia Subduction Zone, where the Juan de Fuca oceanic plate dives beneath North America. Northwest motion of the Pacific plate drags the convergent margin northward, producing clockwise rotation of western Oregon. Bold black arrows indicate clockwise motions of tectonic blocks with respect to relatively fixed North America plate (represented by thumbtack) inferred from geologic and geodetic data. The northward-moving Oregon block (gray brown) squeezes western Washington (purple) against Canada, which creates faulting, folding, and earthquakes in the fore arc. Modified from Sherrod and others (2004) after Wells and others (1998) and Wang and others (2003). $B$ (next page), Geologic map of the northern Willamette Valley region with earthquake epicenters (red dots). Red outline shows the map area of this report. Fault labels: PHF, Portland Hills Fault; BF, Beaverton Fault; CF, Canby Fault; SF, Sherwood Fault; GCF, Gales Creek Fault; MAF, Mount Angel Fault. Figure shows dextral oblique thrust focal mechanism of 1993 M 5.7 Scotts Mills earthquake. Figure after Blakely and others (2000), Evarts and others (2009b), and Thomas and others (1996). 


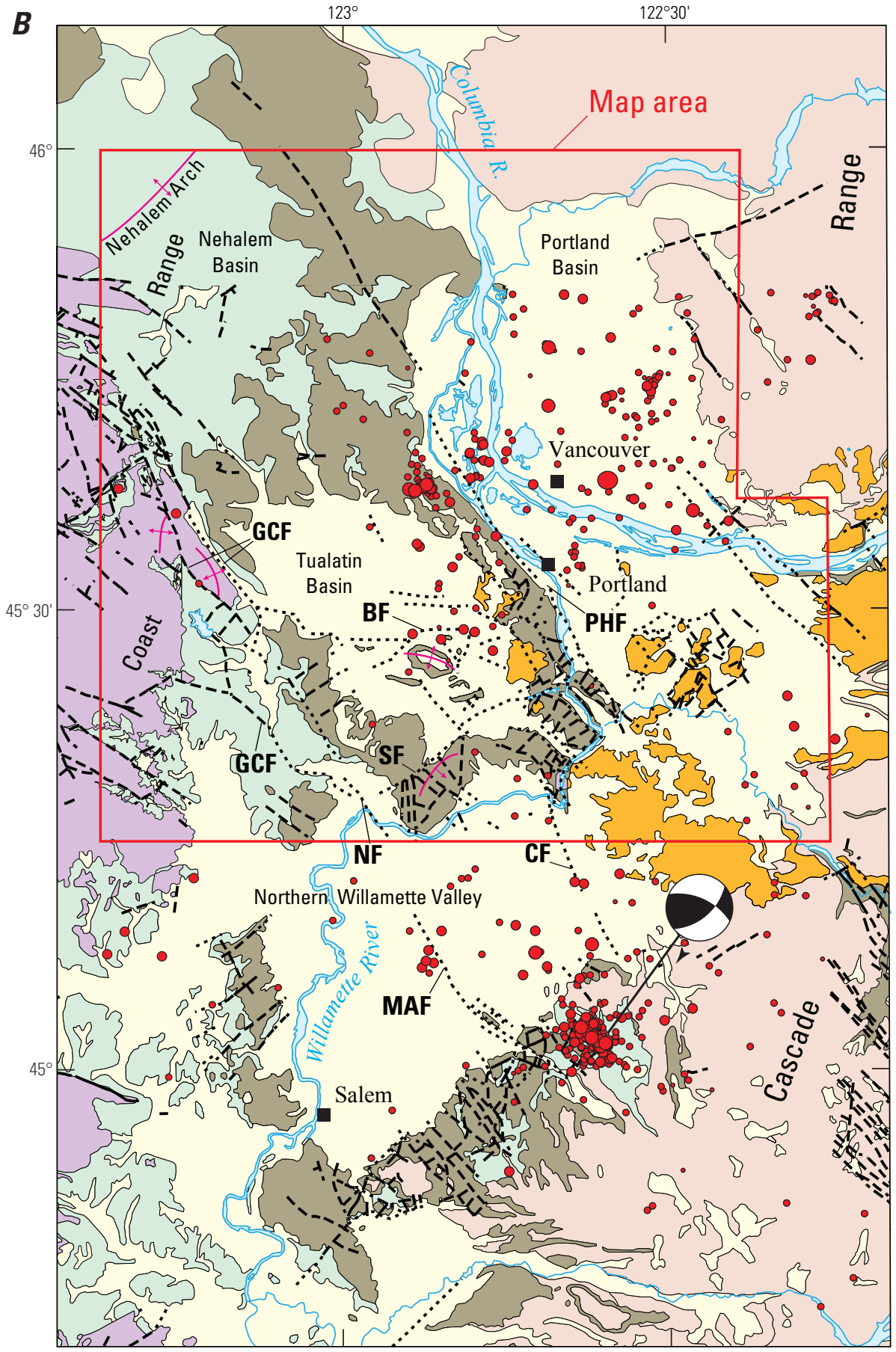

EXPLANATION

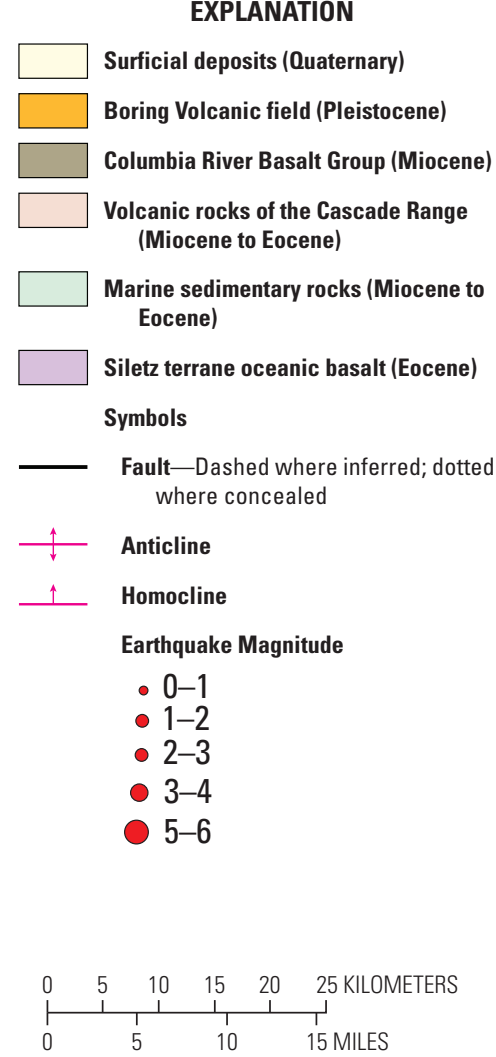

Figure 2. Map showing geologic setting of the greater Portland metropolitan area and surrounding region-Continued

on the east. Earth scientists have been studying the geology of these regions for many decades, primarily to assess hydrocarbon and industrial mineral potential and later to assess groundwater resources and earthquake, landslide, and flood hazards.

Early geologic investigations in the Coast Range were largely motivated by hydrocarbon exploration. Warren and others (1945) and Warren and Norbisrath (1946) documented the extent of Cenozoic volcanic and marine strata in northwestern Oregon, subdivided the sequence into formations, and established their paleontological ages. Van Atta (1971), Niem and Van Atta (1973), and Niem and others (1994) revised the extent of units. Moore $(1963,1976)$ and Addicott (1976) revised the molluscan fossil stages for the Cenozoic units. McDougall (1975), Rau (1981), McKeel (1985), and Rau and Johnson (1999) established foraminiferal microfossil zonation for the Paleogene marine sequence. West and others (2009) produced a digital database of unpublished industry micropaleontologic data for western Oregon and Washington. Newton (1969) and Newton and Van Atta (1976) proposed that the region has potential for natural gas discovery and storage. Following the 1979 discovery of commercial quantities of natural gas at Mist, Armentrout and Suek (1985), Niem and Niem (1985), and Niem and others (1990, 1992, 1994) documented the geology of the western Nehalem Basin, including the Mist gas field, the Astoria Basin, and the adjacent offshore 


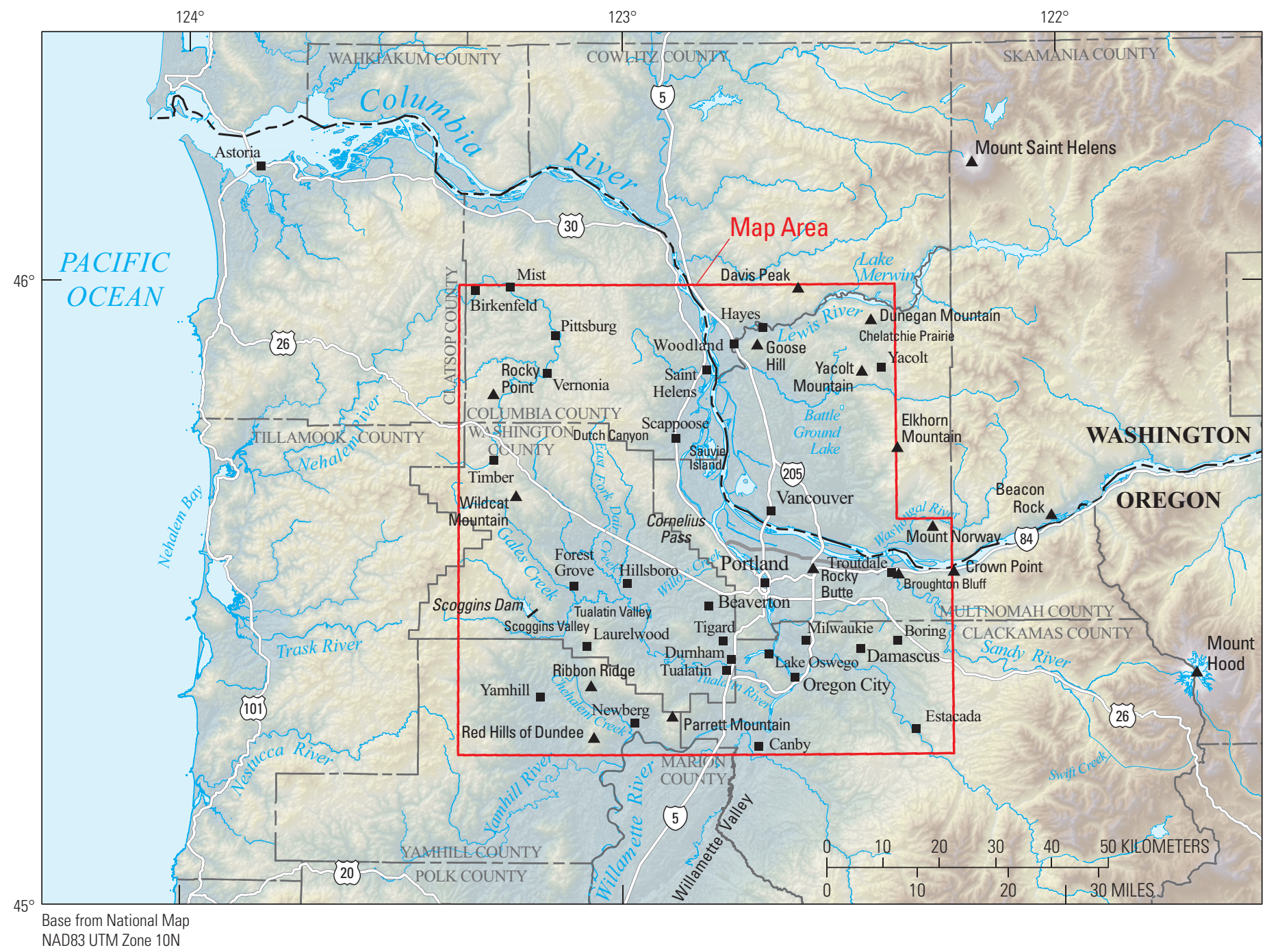

Figure 3. Map showing location of geologic map and geographic locations discussed in the text.

region. Subsequent Coast Range studies established the age and correlation of the volcanic sequences, their structural geology, and the tectonic evolution of the fore arc of the Cascadia Subduction Zone (Wells and others, 1983, 1995, 1998, 2014).

Geologic mapping in the Portland Basin began with the highly generalized assessments of Darton (1909), Diller (1915), and Piper (1942), primarily for water resources and construction materials. Hodge (1938) and Treasher (1942) further detailed the regional geology, but it was Trimble $(1957,1963)$ that provided the first comprehensive geologic map of the central Portland metropolitan area at a scale of 1:62,500 and established the Cenozoic stratigraphic framework and distribution of geologic units for the Portland Basin. Evarts and others (2009a) described the overall basin structure and history, with emphasis on the role of the Columbia River and its interaction with an active volcanic arc. A thorough accounting of previous work in the Portland Basin can be found in Evarts and others (2013).

In the Cascade Range foothills along the eastern margin of the basin, Lowry and Baldwin (1952), Evarts and Swanson (1994), Evarts (2002; 2004a,b,c,d; 2005; 2006a,b), Evarts and O'Connor (2008), Evarts and others (2013), Phillips (1987a,b), Phillips and others (1986), Walsh and others (1987), Scott and others (1997), and Lite (1992) documented the geologic history of the volcanic arc and its interactions with the basin. Evarts and others (2009b) described the Pliocene-Pleistocene Boring Volcanic Field in and around the Portland Basin, and Fleck and others (2014) correlated Boring isotopic ages and magnetic polarities to the geomagnetic polarity timescale. Hart and Newcomb (1965) and Schlicker and Deacon (1967) established the geologic framework for the Tualatin Basin and identified the Gales Creek Fault along its western margin. Beeson and Moran (1979) and Beeson and others (1985, 1989b) established the regional extent of the flows of the Columbia River Basalt Group (CRBG) that reached the Portland and Tualatin Basins. They used the flows as markers to document post-CRBG deformation in the Tualatin Mountains (also known locally as the "Portland Hills") and elsewhere in northwestern Oregon (Beeson and others 1989a,b, 1991; Beeson and Tolan, 1990).

Gannett and Caldwell (1998), Woodward and others (1998), McFarland and Morgan (1996), and Conlon and others (2005) summarized the hydrogeologic framework of the Willamette Valley. Brodersen (1995) examined the CRBG aquifer system on the south flank of the Tualatin Basin at Parrett Mountain, and Burt 
and others (2009) described the groundwater framework of the CRBG related to aquifer storage and recovery within the Tualatin Basin. Wilson $(1997,1998,2000)$ described the post-CRBG history of the Tualatin Basin, its fine-grained sedimentary fill, and the shallow groundwater potential. Hoffstetter (1984) described the subsurface geology of the Portland well field, which supplies water to Portland and surrounding communities.

The Quaternary history of the basins forming the Willamette Valley was described by O'Connor and others (2001). Late Pleistocene, cataclysmic Missoula floods and their deposits within the map area were described by Glenn (1965), Allison (1978), Waitt (1994), O'Connor and others (2001), Allen and others (2009), and Benito and O'Connor (2003). Minervini and others (2003) and Burns and Coe (2012) have compiled maps that visualize the depths to which Missoula floods inundated the northern Willamette Valley and Portland Basin.

Following documentation of geologically recent great earthquakes on the Cascadia Subduction Zone (Atwater, 1987; and recent summary by Atwater and others, 2015), studies were initiated to understand the earthquake and landslide hazards in the Portland metropolitan region (for example, Madin 1990, 2004; Mabey and others, 1997; Wong and others, 2000; Palmer and others, 2007). Yeats and others (1996) examined the subsurface structural geology of the Willamette Valley, and Wong and others (2001) studied the Portland Hills Fault along the base of the Tualatin Mountains as a possible earthquake source. Walsh and others (2011) described the geology of the TriMet Light Rail tunnel and the Quaternary SylvanOatfield Fault System exposed near the western portal. Geophysical studies by Blakely and others $(1995,2000)$ documented the system of strike-slip faults beneath the basins of the metro area (fig. 2). Analysis of gravity data by McPhee and others (2014) showed that the Tualatin Basin is as much as $5 \mathrm{~km}$ deep, with large Paleogene displacement on the Gales Creek Fault, which forms the west margin of the basin. Work on the Quaternary history of the Gales Creek Fault is continuing (Wells and others, 2009, 2020; Redwine and others, 2017, 2019). Ma and others (2012) have documented the shallow surficial-deposits framework and susceptibility to ground shaking of the metro area.

\section{Geologic History}

The metro area overlies the Cascadia Subduction Zone, where lithosphere of the Juan de Fuca plate dives beneath the North America plate. The geology of the region records more than 50 million years of plate convergence, collision of oceanic terranes, deformation, and volcanism generated by subduction, continental extension, and hotspot activity. During this time, the Columbia River has traversed the map area, creating topography and delivering far-traveled sediment from the continental interior. Astride the Columbia River, the metro area lies on the only low-elevation route through the volcanic arc to the continental interior. The metro area's position is unique, because the Columbia River is the solitary instance on Earth of a large river bisecting an active volcanic arc and draining toward an active convergent margin. Volcanic activity, earthquakes, fluvial and marine sedimentation, thick deposits of windblown glacial silt, and megafloods from ice-age glaciers and landslide-dammed lakes on the Columbia River have all contributed to shaping the landscape. Here we outline the major events in this history, beginning with the origin of the oldest rocks $-56 \mathrm{Ma}$ (Mega-annum, age in millions of years) — exposed in the map area.

\section{Accretion of Siletzia and Creation of the Cascadia Subduction Zone (56-44 Ma)}

Paleocene and Eocene oceanic basalts of the 56-49 Ma Siletz River Volcanics (Tsr) form the basement of the Oregon and Washington Coast Range (Snavely and others, 1968; Wells and others, $1995,2000,2014)$. They are restricted to the southwest quadrant of the map area where, west of Gales Creek, the Siletz River Volcanics consist of subaerial tholeiitic basalt flows (Tsra), a silicic ash flow tuff, and interbedded sediments (Tsrf), all overlying submarine pillow basalt flows and breccias (Tsrm) with oceanic island basalt (OIB) and mid-ocean ridge basalt (MORB) chemistry (fig. $4 A, B$ ). These basalts represent part of an ancient oceanicisland chain and plateau similar to the Hawaiian Islands or Iceland that rafted in on the subducting oceanic plate and accreted to North America at about $50 \mathrm{Ma}$ (fig. 5) (Duncan, 1982; Wells and others, 2014). This terrane, which includes the similar Crescent Formation in Washington, is commonly known as Siletzia, named for the Siletz River Volcanics. The calculated volume of basalt comprising Siletzia in the fore arc is about $2 \times 10^{6} \mathrm{~km}^{3}$, making Siletzia a large igneous province (LIP). Many LIPs were created at long-lived hotspots, and plate tectonic reconstructions of the Pacific Northwest suggest that the long-lived Yellowstone hotspot was about $500 \mathrm{~km}$ offshore in the Eocene and could have been the source of Siletzia (Duncan, 1982; Wells and others, 2014). A U-Pb isotopic age of $49 \mathrm{Ma}$ on zircons from the tuff near the top of unit Tsra west of Gales Creek provides an upper limit to the age of the islands (Wells and others, 2014).

Following eruption of the tuff, folding and faulting of the Siletz River Volcanics marked accretion of Siletzia to North America. Deformed Siletz River strata are unconformably overlain by continent-derived deep-marine mudstone and sandstone of the Yamhill Formation (Ty) (fig. 6), which contains a sequence of silicic tuff beds near its base that includes zircons dated at $46.5 \mathrm{Ma}$ by U-Pb methods (Wells and others, 2014). Shortly after accretion of Siletzia, renewed eruptions of MORB pillow basalt between 46 and $45 \mathrm{Ma}$ (Wells and others, 2014) interfingered with the Yamhill Formation (Ty). A related Eocene intrusive suite exposed in the upper Tualatin River gorge west of Scoggins Valley (included in Tis) consists of basalt, diabase, and gabbro sills with MORB compositions that intruded the Yamhill Formation and older rocks of Siletzia (fig. $7 A, B$ ). Associated dikes are rare. Emplacement of this suite is part of a regional intrusive event and may reflect magmatism during formation of a new Cascadia Subduction Zone outboard of the accreted oceanic terrane (Reagan and others, 2010; Wells and others, 2014). The relative buoyancy of the young, warm, 30-kmthick crust of Siletzia probably resisted subduction and precipitated a westward jump of the subduction zone to a position outboard of the clogged subduction zone. Shortly after Siletzia's accretion at about $40 \mathrm{Ma}$, a new magmatic arc in the Cascade Range was constructed on the accreted terrane, substantially west of earlier continental margin magmatism (Sherrod and Smith, 2000). 

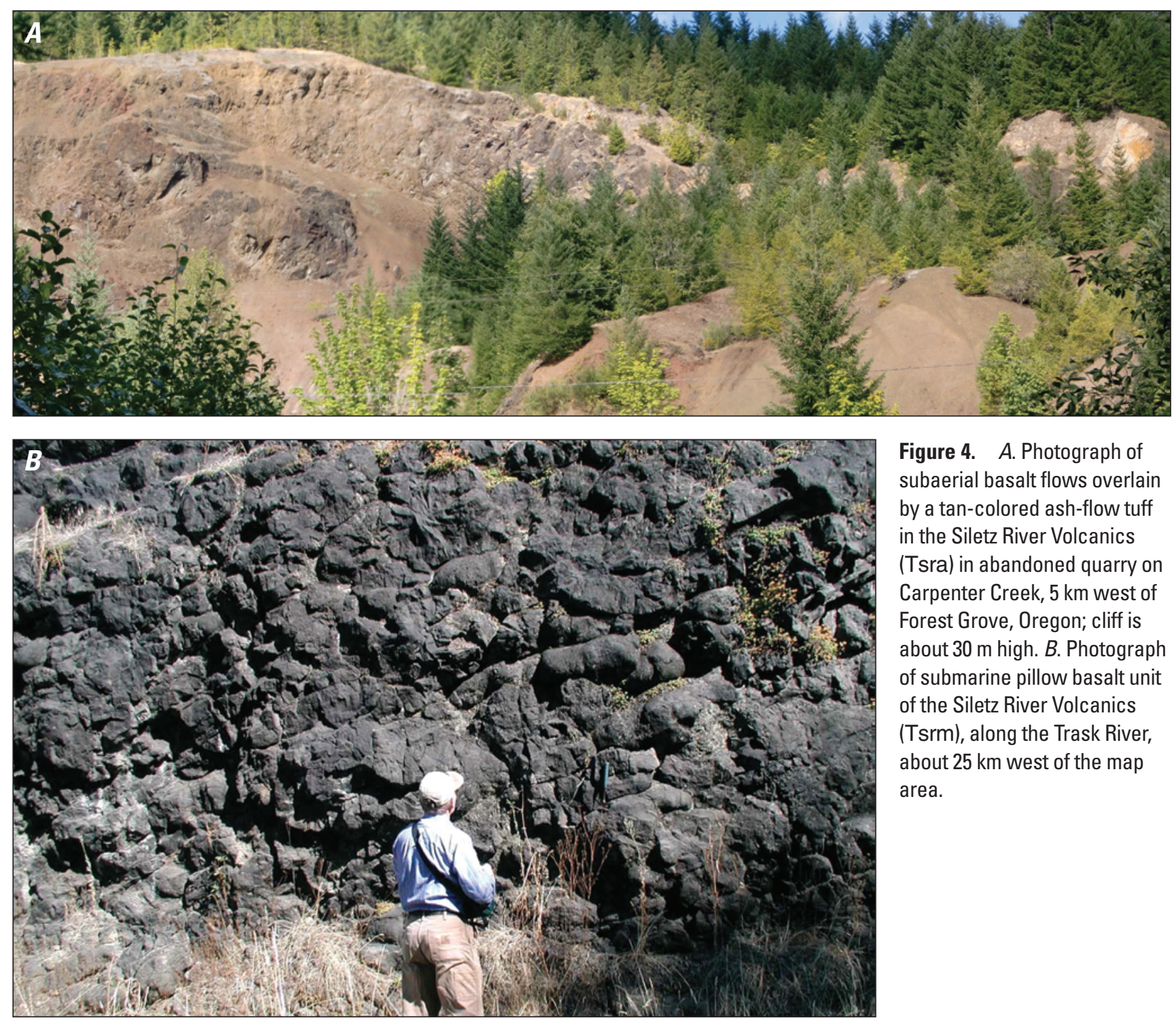

Figure 4. A. Photograph of subaerial basalt flows overlain by a tan-colored ash-flow tuff in the Siletz River Volcanics (Tsra) in abandoned quarry on Carpenter Creek, 5 km west of Forest Grove, Oregon; cliff is about $30 \mathrm{~m}$ high. $B$. Photograph of submarine pillow basalt unit of the Siletz River Volcanics (Tsrm), along the Trask River, about $25 \mathrm{~km}$ west of the map area.

\section{Fore-arc Rifting and Magmatism (42-34 Ma)}

Following the westward jump of the subduction zone, the Siletz terrane became part of the basement of the new Cascadia fore arc and was overlain by marine sediments. About 8 million years after the accretion of Siletzia, a bimodal (basalt-rhyolite) suite of Eocene lavas erupted from west-northwest-trending dike swarms in the nascent Cascadia fore arc. These include the submarine flows and breccias (Ttvm) and overlying subaerial basalt flows (Ttva) of the Tillamook Volcanics (Ttv) exposed in anticlinal uplifts in the upper Gales Creek and Nehalem River drainages (northwest quadrant of map). The flows are dominantly aphyric to abundantly plagioclase-pyroxene-olivinephyric, tholeiitic to alkalic subaerial basalts with high $\mathrm{TiO}_{2}$ contents of 2.5 to 4 percent, typical of oceanic island lavas related to hot spots. Dacite and rhyolite (U-Pb zircon age of 41.6 $\pm 0.4 \mathrm{Ma}$ ) make a few percent of the volcanic pile, which dips gently northeast and is more than $8 \mathrm{~km}$ thick in the Coast Range west of the map area (Wells and others, 1995, 2014). The basalt of Waverly Heights (Tbwh) of Beeson and others (1991) along the Willamette River (fig. 8) is of similar composition and age (44.5 Ma, ${ }^{40} \mathrm{Ar} /{ }^{39} \mathrm{Ar}$ total-fusion age, D. Pyle, University of Hawaii, written commun., 2014; 44.4 to 39.9 Ma, Hammond and others, 2014), consistent with geophysical evidence that the Eocene basalts extend eastward beneath the Willamette Valley (Bromery and Snavely, 1964; McPhee and others, 2014). In the isolated, uplifted block of Tillamook Volcanics that underlie the Green Mountain area in the northwest map quadrant, subaerial flows of platy porphyritic andesite to glassy aphyric iron-rich dacite cap the volcanic sequence. The main Tillamook shield, about $8 \mathrm{~km}$ thick, is about the size of Mauna Loa on Hawaii. It accumulated very rapidly, probably in less than 1 million years, and represents initiation of regional north-south extension and magmatism in the Coast Range that continued episodically, with much smaller volumes until $34 \mathrm{Ma}$ (Wells and others, 2014). This magmatic rejuvenation and marginal rifting may represent subduction of an oceanic spreading ridge and (or) the encounter of the leading edge of North America with the same hotspot that produced Siletzia - for example, a long-lived Yellowstone hotspot (Duncan, 1982; Wells and others, 2014). 


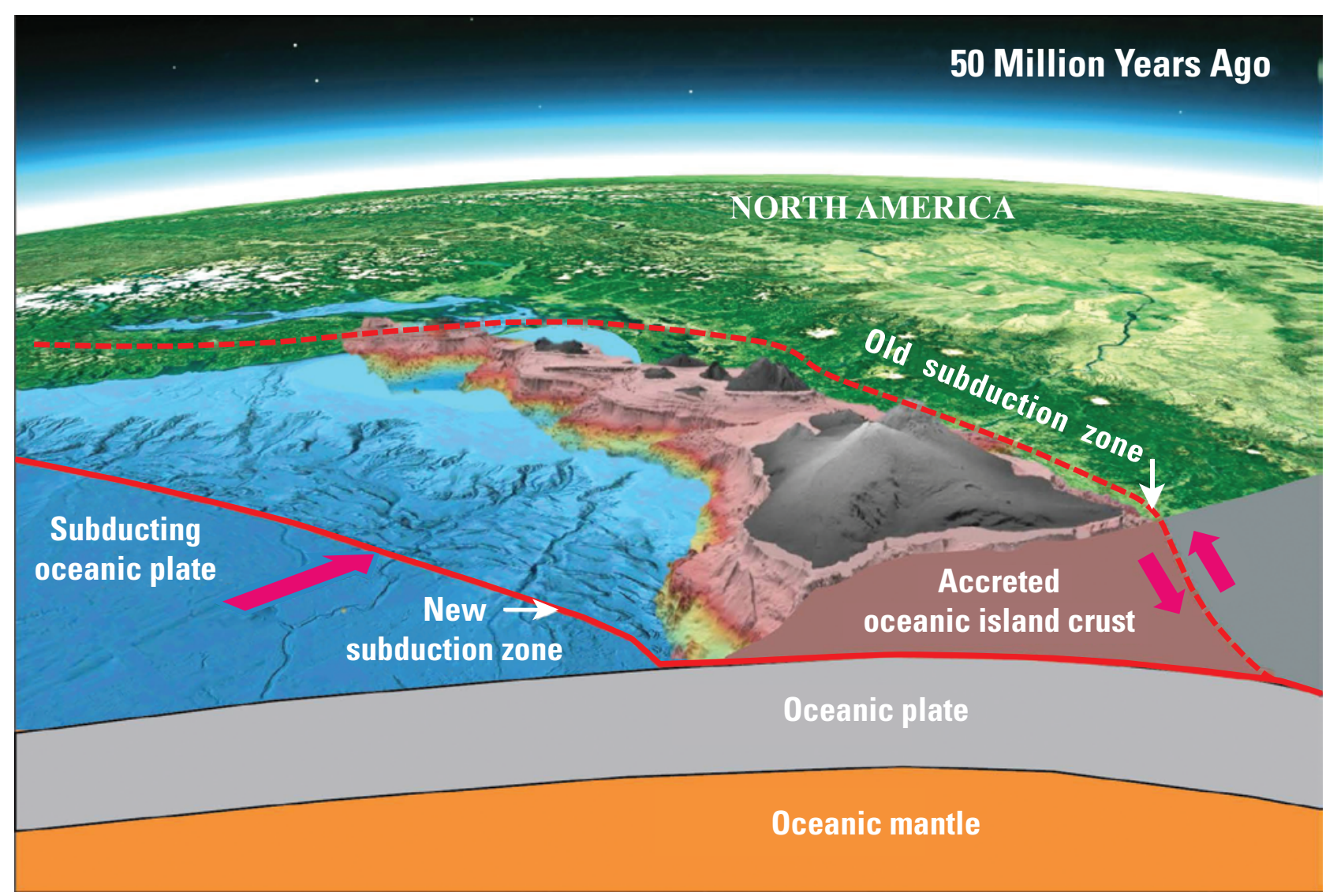

Figure 5. Cartoon showing a basaltic oceanic island chain similar to Hawaii colliding with the North America margin at about 50 million years ago. The thick, young, hot, buoyant crust resisted subduction beneath North America, causing the subduction zone to jump outboard of the newly accreted terrane. Arrows show relative movement.

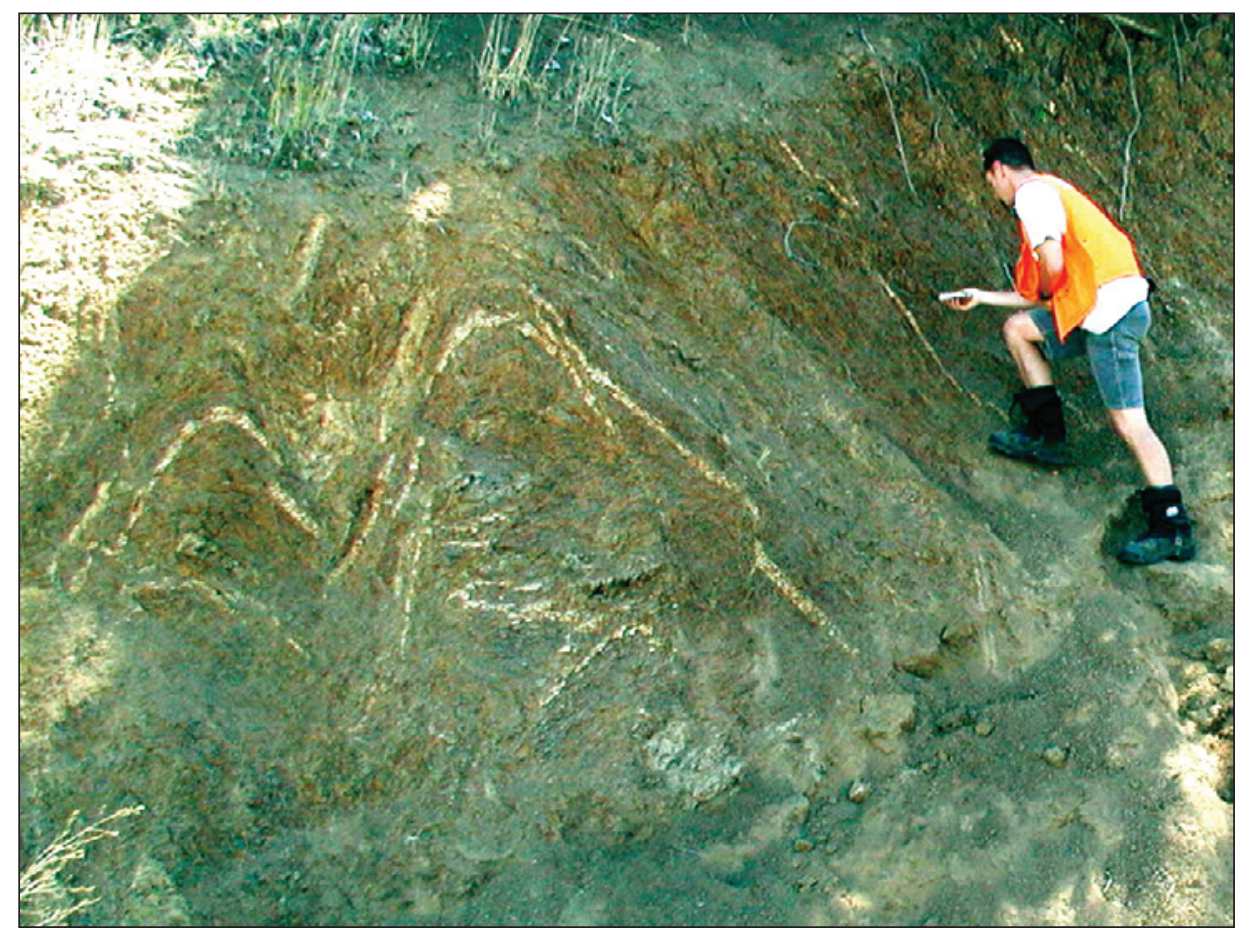

Figure 6. Photograph of folded, thin-bedded mudstone of the Yamhill Formation (Ty) about $5 \mathrm{~km}$ northeast of the town of Yamhill, Oregon. 

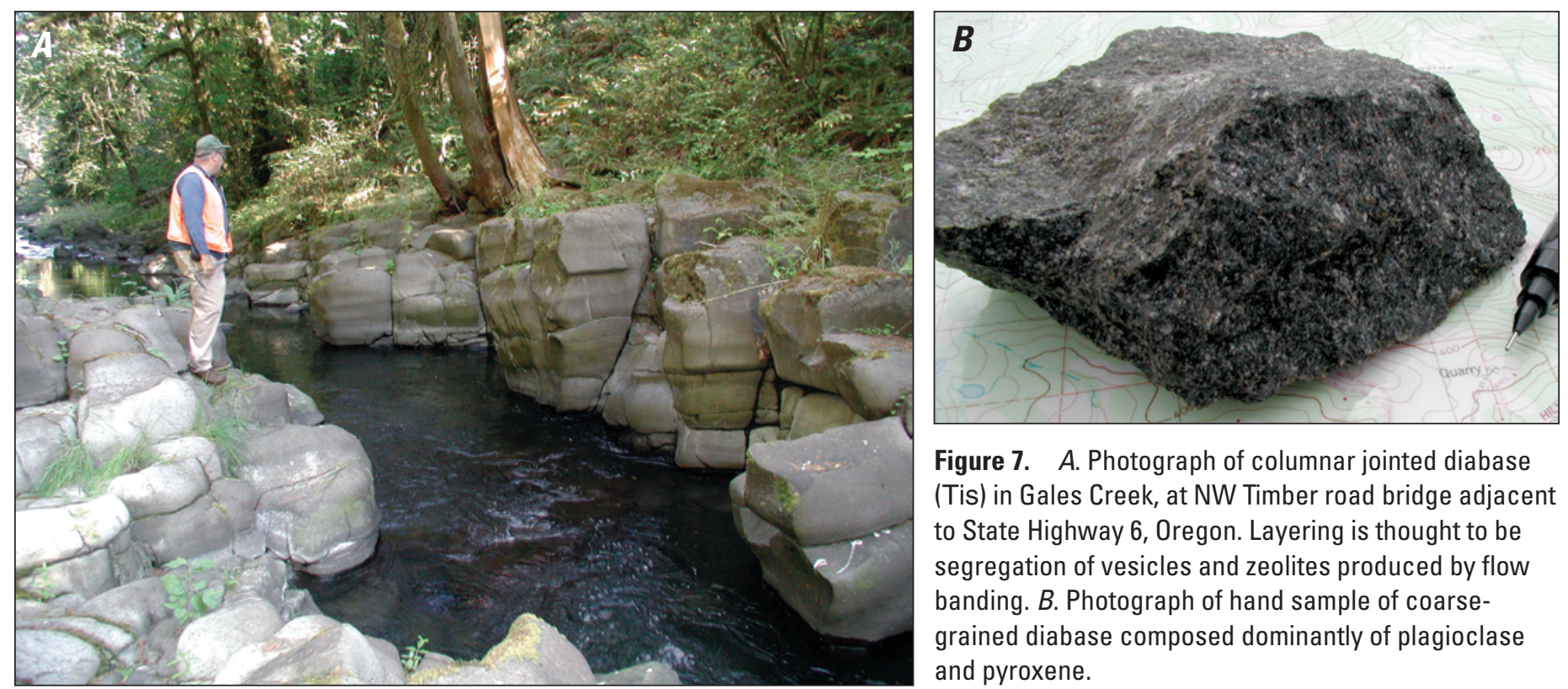

Figure 7. A. Photograph of columnar jointed diabase (Tis) in Gales Creek, at NW Timber road bridge adjacent to State Highway 6, Oregon. Layering is thought to be segregation of vesicles and zeolites produced by flow banding. $B$. Photograph of hand sample of coarsegrained diabase composed dominantly of plagioclase and pyroxene.

Continued subsidence and marine inundation of the Tillamook edifice followed magmatism. In the Nehalem Basin in the northwest quadrant of the map, the subaerial lavas are unconformably overlain by the Hamlet formation (Th), which consists of littoral fossil mollusk-bearing basaltic conglomerate and sandstone of the Roy Creek member (Thr), shallow-marine fossiliferous, micaceous arkosic sandstone of the Sunset Highway member (Ths), and deep-marine micaceous mudstone of the Sweet Home Creek member (Thsw) (Niem and Niem, 1985). Shallow-marine to deltaic coal-bearing, micaceous sandstone of the Cowlitz Formation (Tc) overlies the Hamlet formation and are exposed along the Nehalem River and its tributaries north of the village of Timber. Sand rich in quartz, mica, and potassium feldspar was derived from granitic and metamorphic rocks on the continent far to the east, like those now exposed in eastern Oregon, north-central Washington, Idaho, and Montana, and were delivered to the fore-arc basin by an ancestral river draining the continental interior.

Continued north-south extension in the late Eocene caused normal faulting along west-northwest and conjugate eastnortheast faults that formed structural traps in the Mist gas field, Oregon's only producing field (Niem and others, 1994; Meyer, 2001). The south half of the field extends into the northwestern part of the map area. The sandstone member of the Cowlitz Formation (Tccw) forms the main reservoir of the Mist field (fig. 9). Exploration geologists in the Mist gas field informally named this unit the "C\&W Sandstone" for the Clark and Wilson discovery well (for example, Armentrout and Suek, 1985). A deep-marine, laminated micaceous mudstone member (Tcum), together with the massive, bioturbated tuffaceous mudstone of the Keasey Formation (Tk), forms the capping seal in the Mist field (fig. 10).

\section{Early Cascade Volcanic Arc Activity and Filling of the Fore-arc Basin (40-16 Ma)}

The oldest rocks of the Cascade Volcanic Arc in western Oregon and Washington are dominantly calc-alkaline basaltic andesites, andesites, ash-flow tuffs, and derivative volcaniclastic sedimentary rocks as old as $40 \mathrm{Ma}$ that overlie arkosic, micaceous sandstone of the Cowlitz and Spencer Formations between Centralia, Washington, and Eugene, Oregon (for example, Sherrod and Smith, 2000; Evarts and others, 1987; Retallack and others, 2004). The early Cascade Arc buried the suture between Siletzia and the older continent to the east under several kilometers of arc volcanic rocks (Parsons and others, 1998; Stanley and others, 1996). In the map area, the oldest exposed arc rocks include subaerial basaltic andesite flows and pumiceous breccias and lapilli tuffs of the Goble Volcanics (Togv) that flank the Columbia River north of Portland. In the type area near Goble, Oregon, the Goble Volcanics have yielded an ${ }^{40} \mathrm{Ar} /{ }^{39} \mathrm{Ar}$ plagioclase age of $36.1 \pm 0.3$ Ma (Evarts, 2002). Rocks in the Cascade foothills of southwestern Washington (northeast quadrant of map), in part correlative with the Goble Volcanics, consist of basalt (Tovb), basaltic

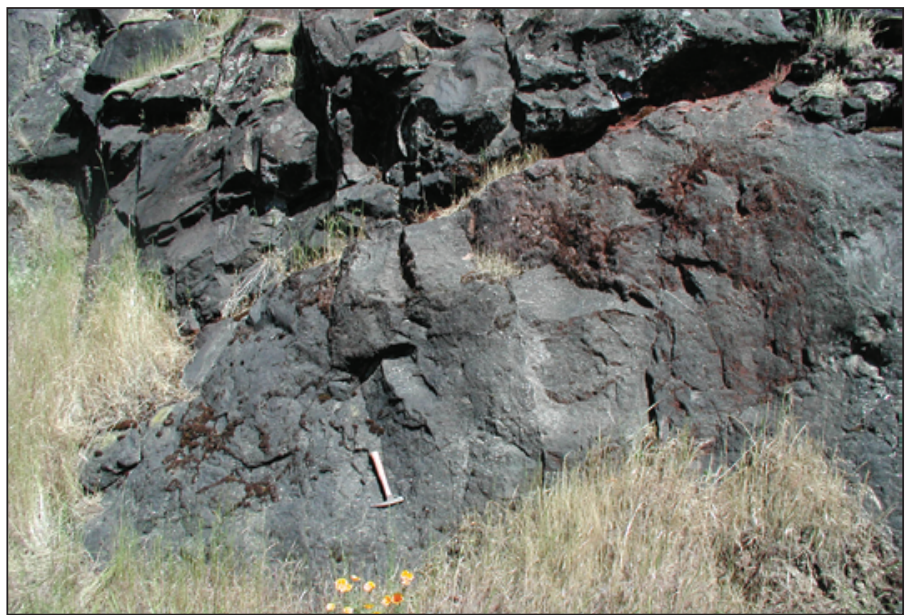

Figure 8. Photograph of columnar jointed to blocky, vesicular basalt of the Eocene basalt of Waverly Heights along the Willamette River, about $10 \mathrm{~km}$ south of Portland, with vesicles filled with lightcolored secondary minerals. Hammer is about $30 \mathrm{~cm}$ long. 


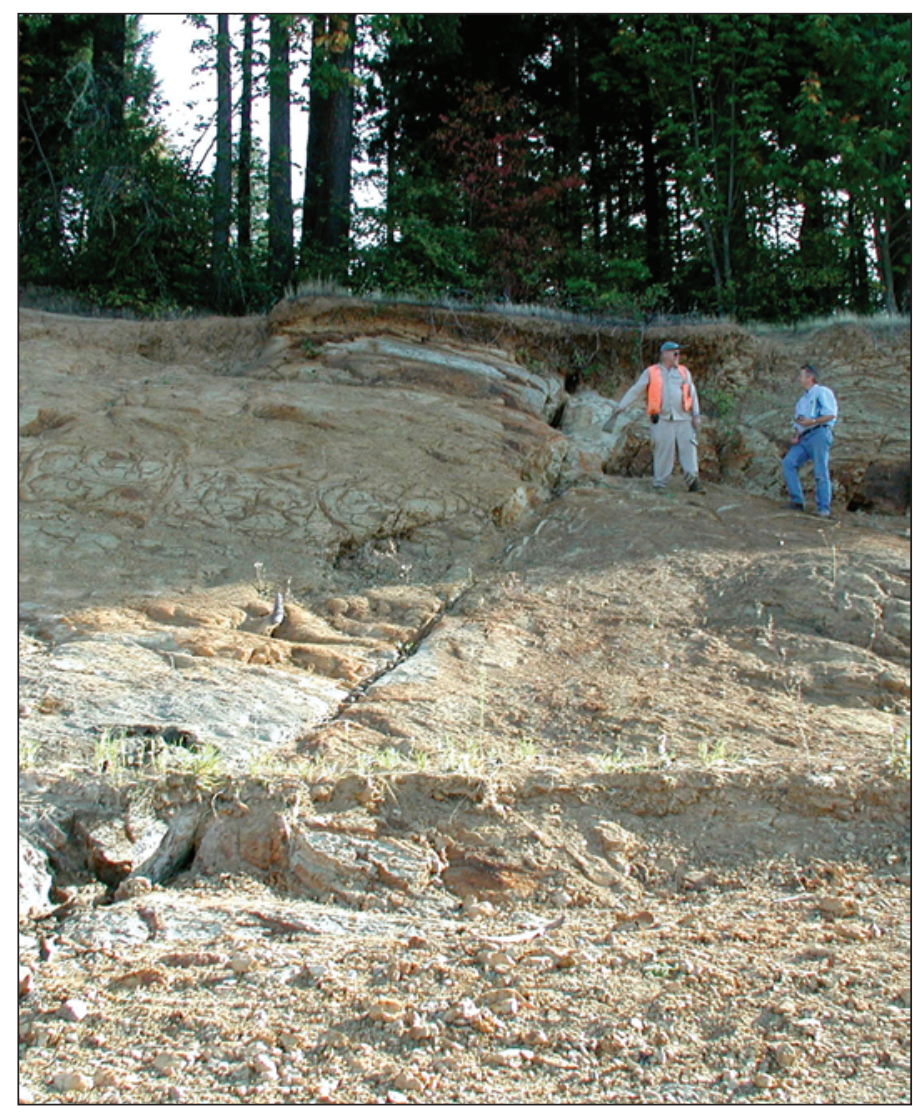

Figure 9. Photograph of bedded micaceous sandstone of the Cowlitz Formation (Tc) at Scoggins Dam, $6 \mathrm{~km}$ southwest of Forest Grove, Oregon. High-angle fault offsets bedding.

andesite (Tovba) (with an ${ }^{40} \mathrm{Ar} /{ }^{39} \mathrm{Ar}$ plagioclase age of $37.3 \pm 0.3$ Ma; Evarts, 2006a), andesite (Tova), dacite (Tovd), and rhyolite (Tovr). They are succeeded by a sequence of ash-flow tuffs (Tot) and volcaniclastic rocks (Tos), including the tuff of Davis Peak (Ttdp), erupted from a caldera at the west end of Lake Merwin in the Ariel quadrangle at about $35.2 \pm 0.3 \mathrm{Ma}\left({ }^{40} \mathrm{Ar} /{ }^{39} \mathrm{Ar}\right.$ plagioclase age, Evarts, 2004a). A sub-regional unconformity representing approximately 5 million years separates a younger sequence of basalt (Tyvb), andesite (Tyva), and dacite (Tyvd) from the older, more heterolithologic suite. The younger suite is dominated by the basaltic andesite of Elkhorn Mountain (Tbem), ranging in age from $27.1 \pm 0.1 \mathrm{Ma}$ to $25.5 \pm 0.2 \mathrm{Ma}\left({ }^{40} \mathrm{Ar} /{ }^{39} \mathrm{Ar}\right.$ plagioclase ages; Evarts, 2006a,b; Evarts and O'Connor, 2008). These are the youngest extrusive rocks in the map area; strata exposed in the Columbia Gorge to the east record a history of vigorous volcanism lasting until about $20 \mathrm{Ma}$, after which volcanic activity in southern Washington declined precipitously (Evarts and Swanson, 1994; Sherrod and Smith, 2000). Magmatism did not end completely, however, as attested to by scattered post-20-Ma intrusions, but arc output was much lower than previously.

Cascade Arc volcanic rocks interfinger westward with marine strata in the fore-arc basin of the Coast Range (Niem and others, 1990, 1992). Total-fusion whole-rock ${ }^{40} \mathrm{Ar}{ }^{\beta 9} \mathrm{Ar}$ ages of subaerial basalt ranging from $38.9 \pm 0.3 \mathrm{Ma}$ to $35.02 \pm 0.26 \mathrm{Ma}$ have been obtained in three exploration wells that penetrate the deeply buried Goble Volcanics west of the Columbia River (Niem, 2009).
Tuffaceous strata of the overlying Eocene Keasey Formation (Tk) consist of volcaniclastic detritus dumped into the fore-arc basin from the newly created Cascade Volcanic Arc to the east (Niem and Niem, 1985; Sherrod and Smith, 2000). A detrital U/Pb zircon age of $36.10 \pm 0.43 \mathrm{Ma}$ was obtained from tuffaceous Keasey Formation mudstone (L. Staisch and C. Holm-Denoma, USGS, written commun., 2019) exposed in a paleoseismic trench across the Gales Creek Fault on the Scoggins Creek-Tualatin River divide (Redwine and others, 2017, 2019). The Stimson Mill member of the Keasey Formation (Tksm) contains Coast Range basalt clasts and is restricted to the flank of the uplifted Siletz River Volcanics southwest of Forest Grove (fig. 11A,B). It contains a thick, reworked marine silicic tuff bed (Tkst) (fig. 11C) with a sharp detrital zircon $\mathrm{U} / \mathrm{Pb}$ age peak of $36.69 \pm 0.16 \mathrm{Ma}$ (L. Staisch and C. Holm-Denoma, USGS, written commun., 2019), and it may represent one of the older Eocene ash-flow tuffs from the Cascades (Retallack and others, 2004). In the Mist gas field, deposition of Keasey Formation over faulted reservoir sands of the Cowlitz Formation (Tccw) further helped to seal the structural traps for natural gas. Eocene and Oligocene sandstone and bioturbated, fossiliferous tuffaceous mudstone of the Pittsburg Bluff Formation (Tpb) and channelized turbidites of the Sager Creek formation (Tsc) disconformably overlie and are incised into the Keasey Formation (Niem and others, 1992, 1994; Meyer and Niem, 2002).

The Pittsburg Bluff Formation consists of three members that are subdivided based on the amount of arc-derived volcanic material they contain. In the Nehalem River drainage (northwest map quadrant), the basal deltaic-estuarine Pebble Creek member (Tpp) consists of coal-bearing, cross-bedded, pebbly, arkosic micaceous sandstone of continental interior source. In contrast, the overlying East Fork member (Tpe) is composed of shallow-marine massive, tuffaceous, light-gray, bioturbated, mollusk-bearing sandy siltstone. Locally overlying the East Fork member is the Scaponia tuff (Tps), which includes a thick, shallow-marine ash and pumice-rich debris-flow deposit with freshwater diatoms probably transported from the volcanic arc. The debris-flow deposit is overlain by thin silicic tuffs. Sanidine from one of the tuffs yielded $\mathrm{a}^{40} \mathrm{Ar}{ }^{39} \mathrm{Ar}$ age of $29.83 \pm 0.03 \mathrm{Ma}$ or early middle Oligocene (P.

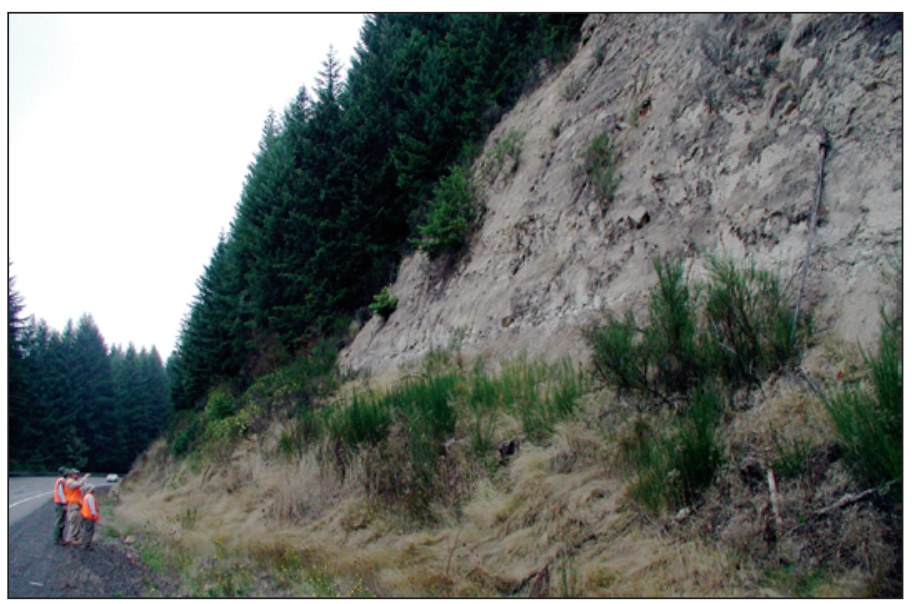

Figure 10. Photograph of tuffaceous, fossiliferous, bioturbated, massive mudstone of the Keasey Formation (Tk), Highway 26, west of Manning, Oregon. 

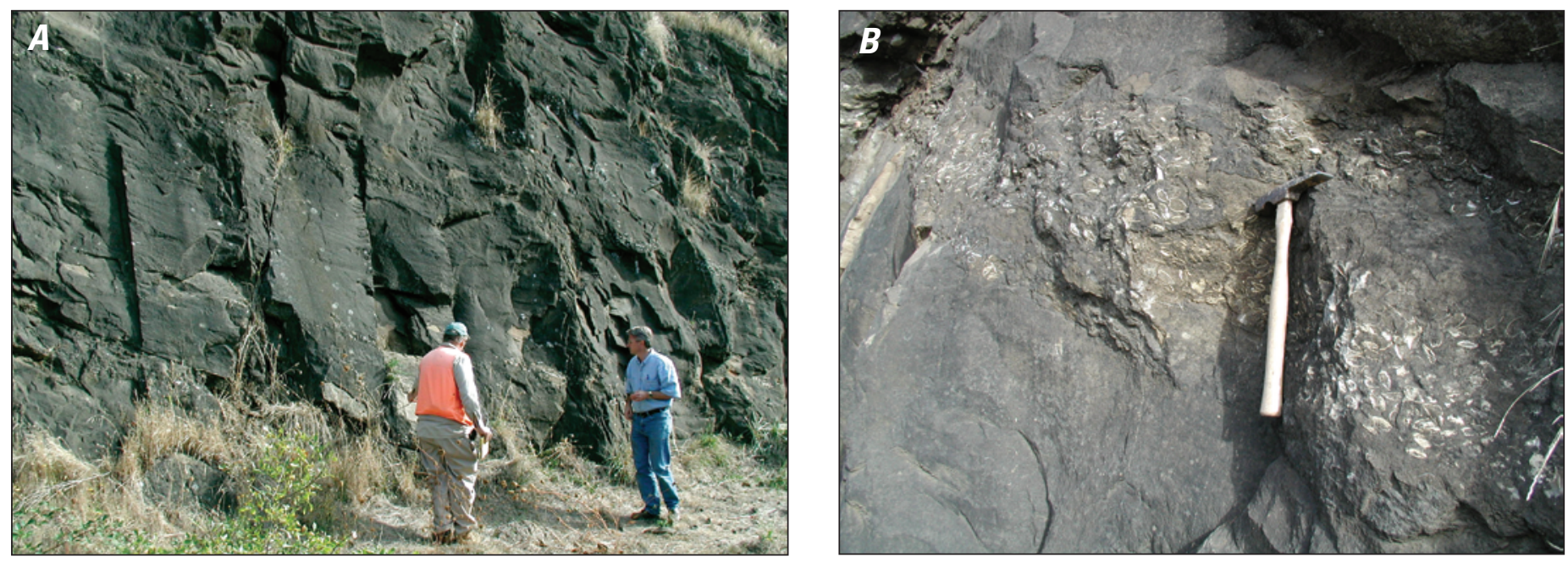

Figure 11. A. Photograph of hard, fine-grained, dark-brownish-gray arkosic basaltic sandstone of the basal Stimson Mill member of the Keasey Formation (Tksm) along Scoggins Valley Road, about 1 km east of Scoggins Dam. B. Photograph of fossil shell bed in shallowmarine sandstone; hammer is about $30 \mathrm{~cm}$ long.

Renne in McKnight and others, 1995). The Scaponia tuff was perhaps derived from lithologically similar ash flows in the Mutton Mountains east of the Cascade Arc. The Sager Creek formation (Tsc) is a lateral equivalent of the deltaic Pebble Creek member that crops out west of Mist in the northwesternmost part of the map near the village of Birkenfeld. It is a thick stack of thinly well bedded micaceous arkosic turbidite sandstone and deep-marine (slope) foraminifer-bearing mudstone deposited in nested submarine channels deeply incised into the Keasey Formation (Meyer and Niem, 2001; Niem and others, 1994).

Deltaic, cross-bedded to laminated micaceous arkosic sandstones of the late Oligocene and early Miocene Scappoose Formation (Ts) (Warren and Norbisrath, 1946; Niem and others, 1994) overlie the Scaponia tuff. The Scappoose Formation consists of the deltaic, coarse-grained, coal-bearing, cross-bedded fossiliferous sandstone of the Divide member (Tsd), deepmarine mudstone of the Oak Ranch Creek member (Tsoc), and coal-bearing sandstone of the Clatskanie River member (Tscr). Note that Moore (1963) considered the strata we call Scappoose to be the upper member of the Pittsburg Bluff Formation. We tentatively consider fine arkosic marine sandstone and mudstone (Tsrs) and associated tuffaceous mudstone (Tsrt) on and near Ribbon Ridge north of Newberg to be part of the Scappoose Formation (fig. 12); these units may correlate in part with the Clatskanie River and Oak Ranch Creek members.

The fore-arc basin fill seems to record explosive pulses of the western Cascade Volcanic Arc throughout late Eocene, Oligocene, and early Miocene. Strata rich in tuffaceous, volcaniclastic material derived from the arc (for example, Keasey Formation [Tk], East Fork member [Tpe], and Scaponia tuff [Tps] of the Pittsburg Bluff Formation and Oak Ranch Creek member of the Scappoose Formation [Tsoc]) alternate with clean, micaceous arkoses (for example, Cowlitz Formation [Tccw], Pebble Creek member of the Pittsburg Bluff Formation [Tpp], and Divide [Tsd] and Clatskanie River members [Tscr] of the Scappoose Formation) that must have been derived from the continental interior farther east.

\section{Flood Basalt Eruptions of the Columbia River Basalt Group (17-15 Ma)}

In the Miocene, between 16.7 and $6 \mathrm{Ma}, 210,000 \mathrm{~km}^{3}$ of flood basalt erupted from fissure vents east of the Cascade Range to produce the Columbia River Basalt Group (CRBG) (Reidel and others, 2013). The basalts formed a vast lava plateau that covered $210,000 \mathrm{~km}^{2}$ of Oregon, Washington, Idaho, and northern Nevada (fig. 13) (Reidel and others, 2013). Individual CRBG lava flows are among the largest on earth, some extending over thousands of square kilometers. The CRBG consists of five formations: Steens Basalt (16.653 \pm 0.063 Ma to16.589 $\pm 0.031 \mathrm{Ma})$, Imnaha Basalt (16.572 $\pm 0.018 \mathrm{Ma}$ ),

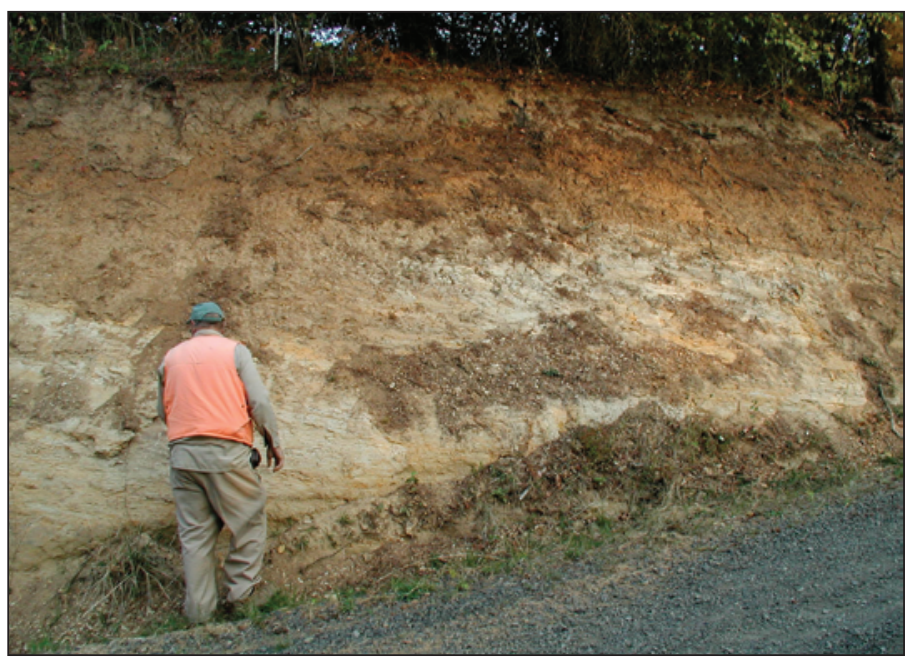

Figure 12. Photograph of fine-grained, cross-laminated, micaceous sandstone of the Scappoose Formation on Ribbon Ridge (Tsrs), about $10 \mathrm{~km}$ northwest of Newberg, Oregon. Red-orange paleosol on sandstone is capped by a thin layer of buff-colored loess beneath the modern soil. 


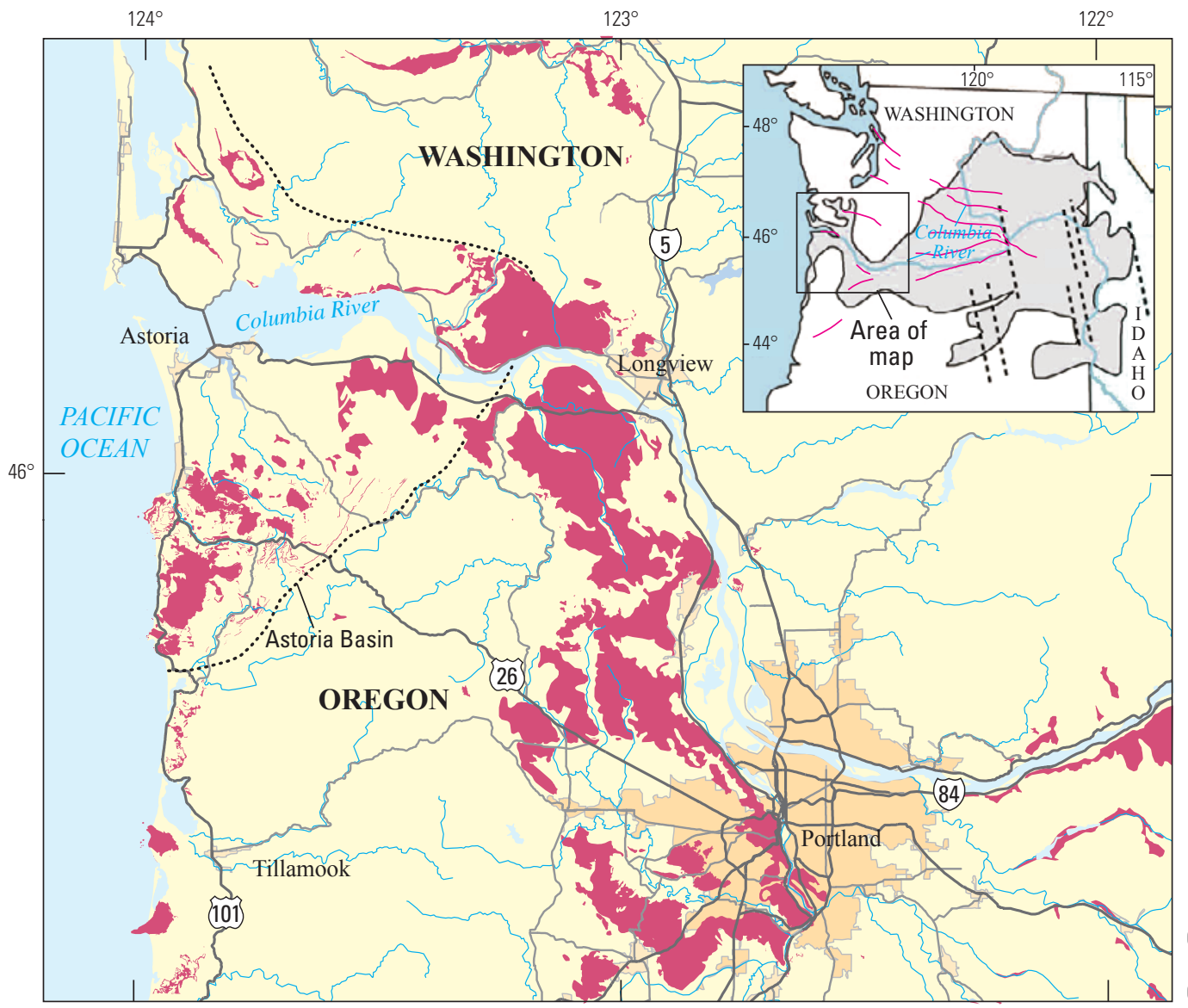

Figure 13. Map of Columbia River Basalt Group (CRBG) in western Oregon and Washington (red areas). Dotted line outlines Astoria Basin. Inset shows area of CRBG in the Pacific Northwest (gray shading), source vents (dashed lines), and Yakima Fold Belt structures (red lines). Modified from Wells and others (2009)

Grande Ronde Basalt (16.5-16.2 Ma; 72 percent of the CRBG by volume), Wanapum Basalt (16.066-15.895 Ma), and Saddle Mountains Basalt (15-6 Ma) (fig. 14; Swanson and others, 1979; Reidel and others, 2013; Kasbohm and Schoene, 2018). Single flows, or groups of a few flows, can be distinguished and mapped across the Pacific Northwest on the basis of variations in physical appearance, abundance and size of sparse plagioclase phenocrysts, paleomagnetic polarity and directions, and chemistry (fig. 15A,B) (Hooper, 2000; Reidel and others, 1989, 2013, Beeson and others, 1985; Martin and others, 2013; Wells and others, 1989, 2009). The stratigraphic terminology in this report follows that of Swanson and others (1979) as revised by Reidel and others $(1989,2013)$ and is based in part on chemical analyses (table 3 at https://doi.org/10.3133/sim3443) of our CRBG samples by the Peter Hooper Geoanalytic Laboratory at Washington State University (Johnson and others, 1999).

More than 25 flows crossed the Cascade Range through a long-lived trans-arc lowland near the present Columbia River (Tolan and Beeson, 1984; Beeson and others, 1989a; Wells and others, 1989, 2009), and at least 10 flows reached the Pacific Ocean (Beeson and others, 1979, 1989a,b; Snavely and others, 1973; Niem and Niem, 1985; Tolan and others, 1989, 2009; Beeson and Tolan, 1990; Wells and others, 1989, 2009). Flows of the Grande Ronde, Wanapum, and Saddle Mountains Basalts all reached the Pacific Ocean via an ancestral Columbia River (Snavely and others, 1973; Beeson and others, 1979; Niem and Niem, 1985; Wells and others, 1989, 2009), but only Grande Ronde and Wanapum flows have been found within the map area.
The Grande Ronde Basalt consists of thick flows (as much as $30 \mathrm{~m}$ thick) of tholeiitic basaltic andesite, with $\mathrm{MgO}$ contents ranging from 3 to 6 percent and $\mathrm{TiO}_{2}$ contents from 1.8 to 2.4 percent. It has been subdivided into members based on magnetic polarity, chemistry, and stratigraphic position (figs. 14, 15). The flows are columnar jointed at the base, typically overlain by hackly jointed entablatures, and are aphyric to very sparsely plagioclase-phyric. Wanapum Basalt consists of thick flows, many with well-developed colonnades forming columns as much as $2 \mathrm{~m}$ in diameter and containing sparse to moderately abundant large plagioclase phenocrysts $\left(0.5\right.$ to $2 \mathrm{~cm}$ long). They are consistently higher in $\mathrm{P}_{2} \mathrm{O}_{5}$ and $\mathrm{TiO}_{2}$ than Grande Ronde Basalt flows (fig. 15A).

CRBG flows in the map area filled a dissected lowland of some relief. CRBG rests unconformably on older strata ranging in age from the Eocene basalt of Waverly Heights (44.5 Ma) in the southern Portland Hills and Goble Volcanics ( $\sim 37 \mathrm{Ma})$ in the Deer Island quadrangle (Evarts, 2002; northwest map quadrant) along the Columbia River to the Oligocene-early Miocene Scappoose Formation (Ts) on the east flank of the Coast Range. The base of the Grande Ronde Basalt interfingers with the middle Miocene Mist formation and undifferentiated fluvial clastic rocks (Tmic). The thickness of the flow sequence varies from 30 to more than $330 \mathrm{~m}$ over a few kilometers, as seen along the ridge top on Chehalem Mountains (southwest map quadrant). The irregular distribution of the fluvial Mist formation (Tmic, Tmwr, Tmgc in southwest map quadrant) suggests an incised paleovalley and drainage system that extended across eroded, gently folded Paleogene and early Neogene marine strata of a low-lying 


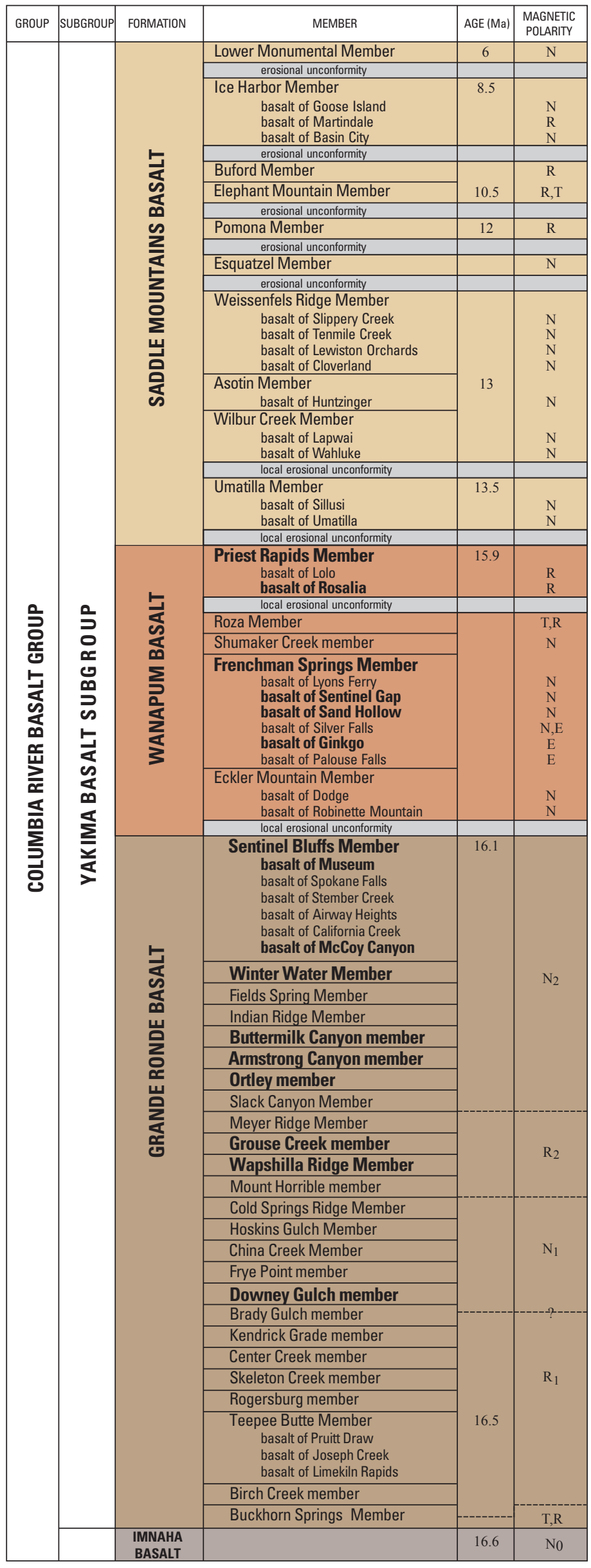

Figure 14. Columbia River Basalt Group stratigraphic chart, after Evarts and others (2013), Reidel and others (2013), and Kasbohm and Schoene (2018). Units in bold are found in the map area.

Coast Range in CRBG time. Following emplacement, the flatlying flows were gently folded and faulted to form the Portland, Tualatin, and Northern Willamette Basins, separated by the Portland Hills and Parrett Mountain-Chehalem Mountains uplifts (fig. $2 B$; Beeson and Tolan, 1990). A database of water-well logs in the map area provides subsurface evidence of the CRBG at depth and its stratigraphic variability (Wilson, 1997; http://or.water.usgs. gov/projs_dir/crbg/data/index.html). Surface exposures of the CRBG in the map area are poor because of intensive weathering to thick, red laterite, typically capped by several meters of windblown loess (fig. 16). The best exposures are in quarries, borrow pits, road cuts, and incised stream channels.

Most of the CRBG flows in the map area belong to the Grande Ronde Basalt. The oldest recognized Grand Ronde Basalt flows are exposed in an old borrow pit on Wildcat Mountain (Buxton quadrangle, northwest map quadrant), where three flows have been referred to the N1 magnetostratigraphic unit (MSU) flows of Swanson and others (1979) and the informal Downey Gulch Member (Tgdg) of Reidel and Tolan (2013), based on their moderate $\mathrm{TiO}_{2}$ and low $\mathrm{MgO}$ contents, normal polarity, and stratigraphic position below a reverse polarity flow (R2 MSU) of higher $\mathrm{TiO}_{2}$ Wapshilla Ridge member chemistry (Dinterman and Duval, 2009; see fig. 5 and Reidel and others, 2013, for Grande Ronde Basalt chemistry and descriptions). Downey Gulch flows are not found anywhere else except along the Wildcat Mountain ridge south to the Highway 6 road cut, and they have pillowed bases, indicating emplacement in a paleo-river valley. The overlying Wapshilla Ridge member (Tgwr) varies greatly in thickness and is locally absent at the north end of Chehalem Mountains. Although buried by younger flows, its subsurface extent in the Tualatin Basin can be inferred from the water-well log database and characteristic aeromagnetic anomaly lows associated with outcrops of the reversely polarized flows (for example, on Chehalem Mountains; Blakely and others, 2000). In the quarries south of Laurelwood, at least five magnetically reversed flows with pillowed bases are interbedded with fluvial basaltic gravel, sandstone, and mudstone. This sequence, about $100 \mathrm{~m}$ thick, is exposed in a mega-landslide block (fig. 17A,B). It is interpreted to be a detached portion of an intracanyon flow sequence that once connected to the flows exposed along the west face of Chehalem Mountains and on Parrett Mountain. In the northwestern part of the map area, a Wapshilla Ridge flow is erosionally truncated by 2 to $20 \mathrm{~m}$ of fluvial basalt pebble-boulder channel conglomerate of the Gus Creek conglomerate of the Mist formation, which is overlain by flows of the informal Grouse Creek member of Reidel and Tolan (2013). Grouse Creek member flows (Tggc) are reversely polarized (R2 MSU) but have lower $\mathrm{TiO}_{2}$ and higher $\mathrm{MgO}$ than Wapshilla Ridge flows. They crop out at the southwest end of Parrett Mountain and northwest of the town of Scappoose, Oregon, along a broad paleovalley subparallel to the northwest-trending Clatskanie-Scappoose Fault Zone. The variable thickness and distribution of the overlying normally polarized (N2 MSU) flows of the informal Armstrong Canyon (Tgac) 

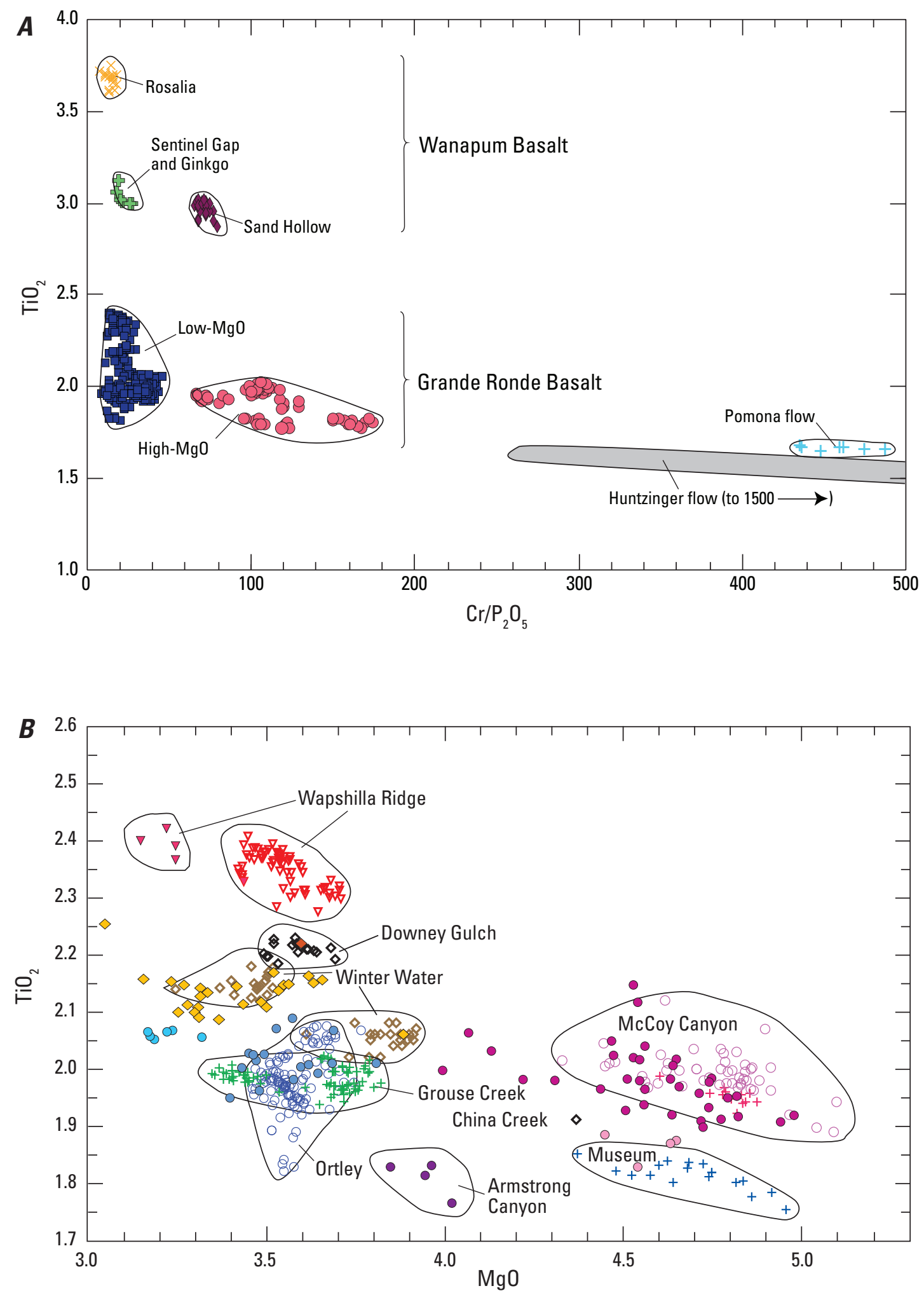

Figure 15. A. Graph of $\mathrm{TiO}_{2}$ versus $\mathrm{Cr} / \mathrm{P}_{2} \mathrm{O}_{5}$ for selected members in the Columbia River Basalt Group (from Wells and others, 2009) B. Graph of $\mathrm{MgO}$ versus $\mathrm{TiO}_{2}$ percentage for Grande Ronde Basalt geochemistry samples from fields recognized by R.C. Evarts in the western Columbia Gorge (Wells and others, 2009). Open symbols are from the gorge. 


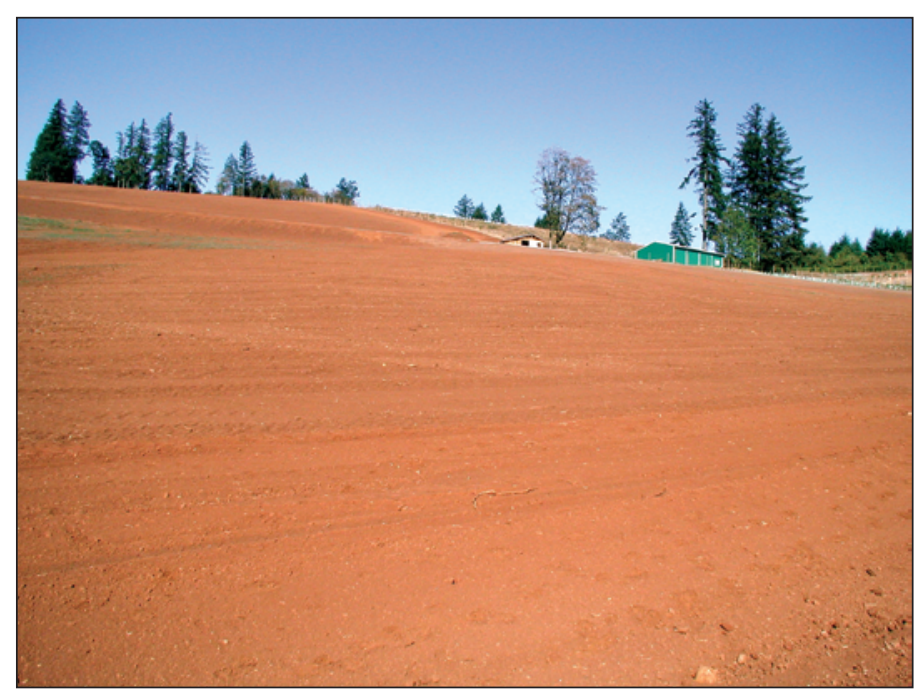

Figure 16. Photograph of thick, red-orange soil of the Jory series typically developed on flows of the Columbia River Basalt Group in western Oregon. Hillslope in the Dundee Hills is being cleared to plant a vineyard.

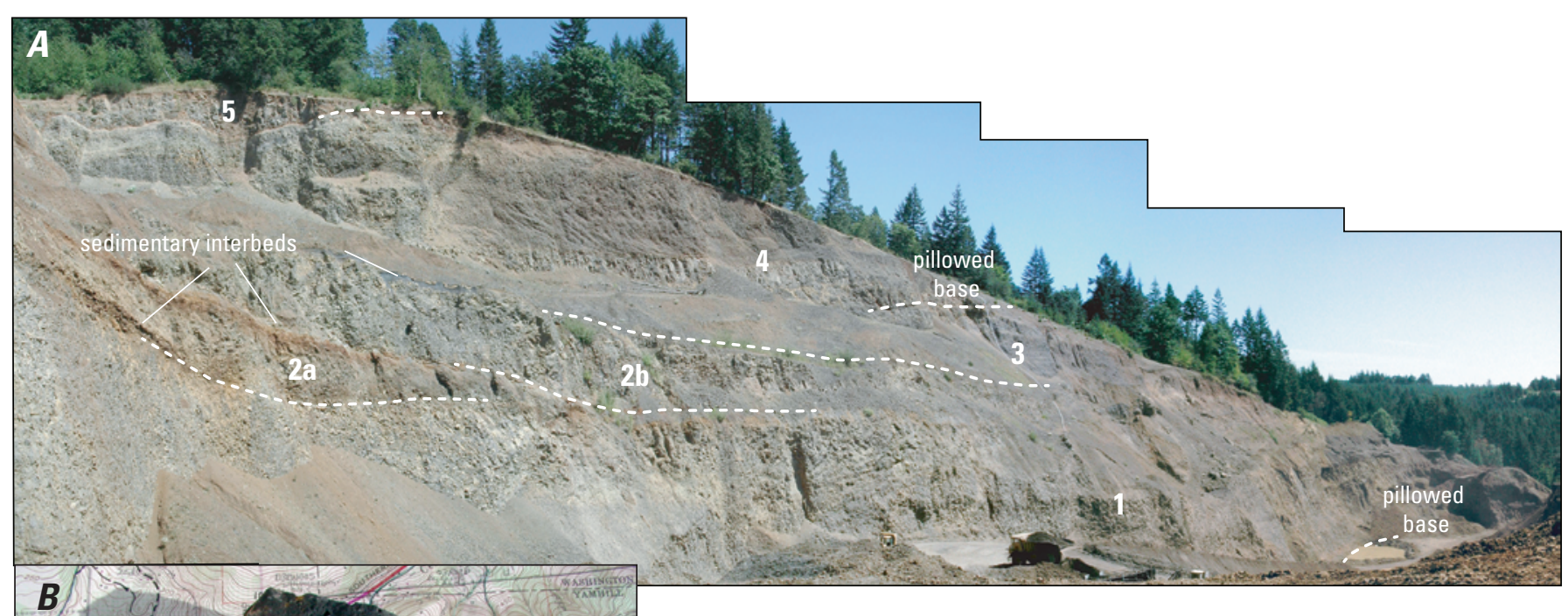

Figure 17. A. Photograph of Wapshilla Ridge member of the Grande Ronde Basalt of the Columbia River Basalt Group (Tgwr) in a quarry about $2 \mathrm{~km}$ south of Laurelwood. Quarry face is about $100 \mathrm{~m}$ high. Five reverse polarity flows and flow lobes dominated by thick entablatures and thin colonnades, each with pillowed bases and separated by mudstone and sandstone interbeds, suggest emplacement in a valley along the margin of the adjacent Coast Range. Flow contacts are dotted and flows numbered; $2 \mathrm{a}$ and $\mathrm{b}$ are interpreted as flow lobes. $B$. Hand sample of Wapshilla Ridge member showing characteristic, abundant microphenocrysts of plagioclase 1-2 mm long.

and Buttermilk Canyon (Tgbc) members and the Ortley member (Tgo) indicate that they also were filling topographic lows in the metro area lowland. In contrast, N2 flows of the Winter Water Member (Tgww) and Sentinel Bluffs Member (Tgsb) at the top of the Grande Ronde section are widespread and more uniform in thickness, probably because most topographic irregularities had been filled by earlier flows. The Winter Water Member consists of two or three flows recognizable by sparse, small $(<10 \mathrm{~mm})$, ragged, stellate plagioclase glomerocrysts and transitional, shallow, northwest paleomagnetic directions. The Sentinel Bluffs
Member consists of two or three columnar-jointed flows (Reidel, 2005) at the top of the Grande Ronde section, with high $\mathrm{MgO}$ (4.5-5.5 percent) and low $\mathrm{TiO}_{2}$ (1.7-1.9 percent) compositions and sparse, equant small plagioclase phenocrysts.

The Vantage Member of the Ellensburg Formation is a regional sedimentary unit and, locally, a paleosol separating the Grande Ronde Basalt from the overlying Wanapum Basalt, which represents a time in which the basalt eruption rate decreased and the flow chemistry changed. Within the map area, the Vantage Member (Tv) is a channelized, 30-m-thick 

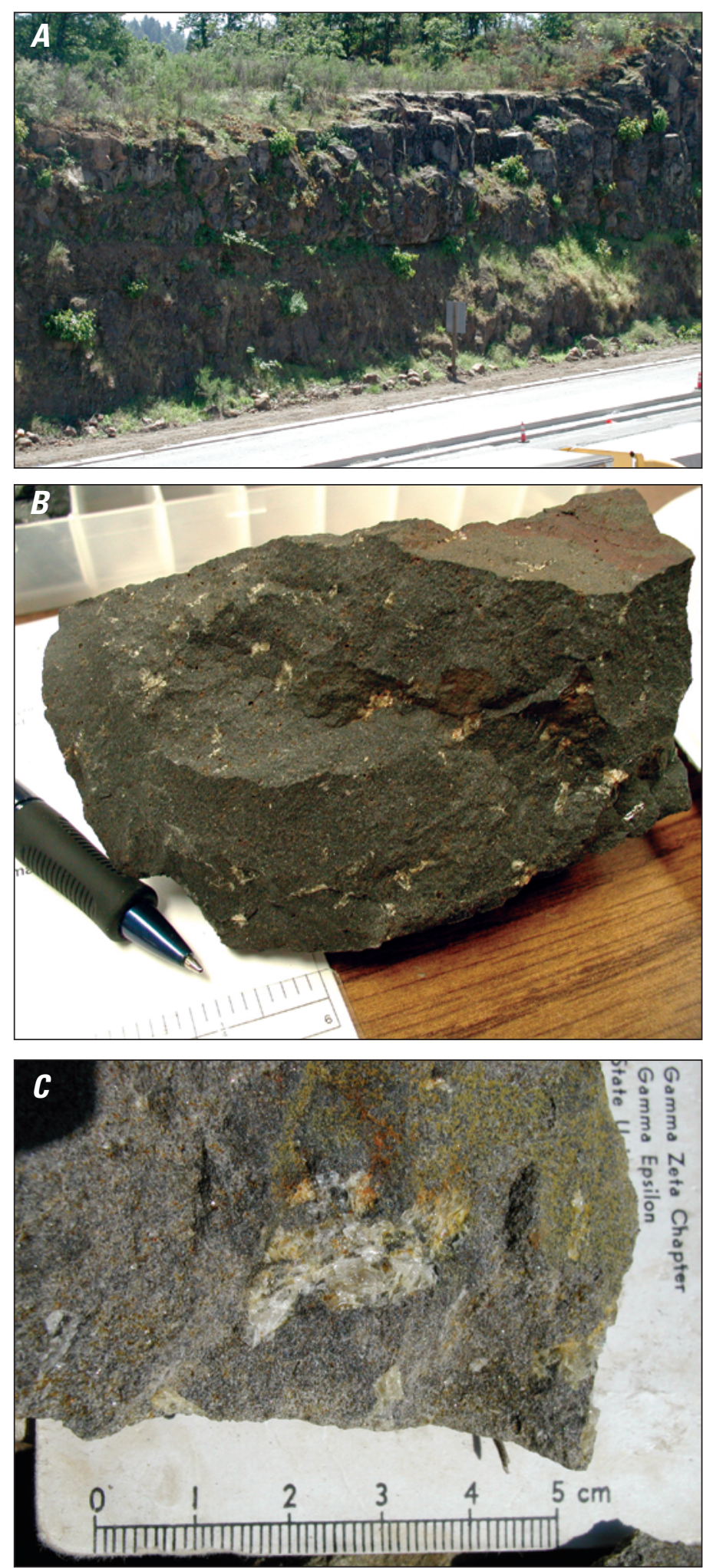

Figure 18. A. Photograph of the Frenchman Springs Member of the Wanapum Basalt on Interstate 205 near West Linn, Oregon. Flows typically form large colonnades, with columns up to $2 \mathrm{~m}$ wide. Sign is about $3 \mathrm{~m}$ high. $B$. Hand sample showing presence of abundant megacrysts of plagioclase feldspar as much as $2 \mathrm{~cm}$ across that characterize the flows of Ginkgo, a subunit in the Frenchman Springs Member. $C$. Hand sample showing plagioclase megacrysts in the flows of Ginkgo that can exceed $2.5 \mathrm{~cm}$ diameter. cross-bedded fluvial basalt conglomerate and minor volcanic feldspathic sandstone locally exposed in the northwestern part of the map area. Other beds of micaceous arkosic sandstone and volcanic/tuffaceous sandstone, lacustrine mudstone, and limonite deposits (Hotz, 1953) are locally present between CRBG flow units but are too thin to show at this map scale.

Wanapum Basalt is widespread on top of the Grande Ronde Basalt in the map area, although commonly weathered and buried under several meters of deep red laterite and overlying tan loess. Ginkgo flows of the Frenchman Springs Member (Twfg) are particularly distinctive (fig. 18A,B), containing abundant, large plagioclase glomerocrysts as much as $2.5 \mathrm{~cm}$ in length and exhibiting transitional paleomagnetic directions (Sheriff, 1984). Sand Hollow flows of the Frenchman Springs Member (Twfh) are typically sparsely porphyritic, but, in the northwest quadrant, flows with Sand Hollow chemistry also have large (as much as 2 $\mathrm{cm}$ ) plagioclase phenocrysts with abundant acicular plagioclase microlites (1-3 mm long) in the groundmass. Areas mapped as flows of Sand Hollow in the Trenholm and Chapman quadrangles (northwest quadrant) may include some older or younger flows. In the Washougal quadrangle at the mouth of the Columbia Gorge, flows of Sentinel Gap (Twfs) of the Frenchman Springs Member are exposed on the Oregon side, and the Rosalia flow (Twpr) of the Priest Rapids Member of the Wanapum Basalt forms a thick intracanyon flow on the south side of the gorge beneath Crown Point (Waters, 1973; Tolan and Beeson, 1984; Evarts and others, 2013).

Some invasive dikes, sills, and irregularly shaped bodies of Columbia River Basalt (including Grouse Creek member, Winter Water Member, and basalt of Sand Hollow) invaded late Oligocene shallow-marine Scappoose Formation and early-middle Oligocene Pittsburg Bluff Formation sandstone in the northwest map quadrant. Isolated basalt occurrences (for example, the basalt of Sand Hollow in the Deer Island quadrangle), which are pillowed to subaerial flows, fill paleovalleys incised into the Oligocene Scappoose and Pittsburg Bluff Formations. The position of these isolated flows topographically below most Grande Ronde and Wanapum Basalt flows suggests the isolated flows filled a canyon system eroded into older units.

\section{Filling the Lowland Basins (15-0 Ma)}

Subsidence of the Portland, Tualatin, and Northern Willamette Basins continued after 17-15 Ma emplacement of the CRBG flows, forming shallow downwarps filled with post-CRBG fluvial and lacustrine sediments and volcanic rocks. About $360 \mathrm{~m}$ of sediment overlies CRBG in the Tualatin and northern Willamette Basins, and about $600 \mathrm{~m}$ of sediment overlies CRBG in the Portland Basin. In all three basins, the top of the CRBG is below sea level, as deep as $-500 \mathrm{~m}$ in the center of the Portland Basin (Gannett and Caldwell, 1998; Popowski, 1996; Wilson, 1997, 1998).

Neogene continental sedimentary rocks of the Portland Basin consist of continental fluvial and lacustrine detritus, transported into the basin by the ancestral Columbia River, that mixed with locally derived detritus (Evarts and others, 2009b). These strata traditionally have been divided into fine-grained fluvial mudstone and sandstone of the Sandy River Mudstone (Tsm) and overlying fluvial conglomerate of the Troutdale Formation (Tt) 
(Trimble, 1957, 1963; Mundorff, 1964). Conglomerates of varying ages underlying the Missoula flood deposits have been attributed to the Troutdale Formation in some reports (for example, Schlicker and Deacon, 1967). Mapping by Evarts and colleagues (Evarts 2002, 2004a,b,c,d, 2005, 2006a,b; Evarts and O'Connor, 2008), Evarts and others (2013), and Howard (2002), summarized by Evarts and others (2009a), subdivides the Troutdale Formation into a lower Miocene and Pliocene quartzite-bearing conglomerate member of Columbia River source (Ttc) and an upper member of basaltic, hyaloclastite sandstone (Tth) derived from tholeiitic basalt flows that entered the Columbia River upstream. Evarts and others (2013) describe the Troutdale conglomerate member as consisting of "weakly to moderately cemented pebble and cobble conglomerate and scattered thin lenses of medium to coarse sandstone. Well-rounded pebbles and cobbles eroded from the CRBG are the most abundant constituent of the conglomerate; the remainder includes light-colored granitic and quartzofeldspathic metamorphic rocks, Fe-oxide-stained quartzite, and minor amounts of volcanic rocks eroded from the Cascade Range." Both units interfinger with fine-grained fluvial mudstone typical of the underlying Sandy River Mudstone. Interfingering with the hyaloclastite are 3.6 to $3.0 \mathrm{Ma}$ low-potassium tholeiitic flows from the Cascades to the east (Evarts and others, 2013). Unconformably over the hyaloclastite are two unnamed conglomerates with a Cascade (QTca) and Columbia River (QTcr) source (fig. 19) that interfinger with lavas of the Pleistocene Boring Volcanic Field (Evarts and others, 2013). In the southeast corner of the map area, Miocene volcanic breccias and flows of the Rhododendron Formation underlie Sandy River Mudstone.

During most of their filling, the Tualatin and Portland Basins were apparently separated by a high in the vicinity of the Portland Hills (Wilson, 1998). In the Tualatin Basin, freshwater diatom-bearing lacustrine mudstone and sandstone forming the late Miocene to Pleistocene Hillsboro formation of Wilson (1998) (QTh) were deposited by low-energy, meandering rivers largely flowing from the Coast Range. About $365 \mathrm{~m}$ of the Hillsboro formation overlying the CRBG has been described from drill core at Hillsboro (Wilson, 2003).

Fill deposited in the Willamette Basin after the CRBG is largely volcanic detritus derived from the Cascade Range, with a minor component of sedimentary infill derived from the Coast Range (O'Connor and others, 2001).

Widespread lateritization of the top of the CRBG (Libbey and others, 1945), the occurrence of deeply weathered basaltic colluvium (unit Qcb) that is restricted to low-relief upland surfaces in Columbia County, and thick loess deposits that are similarly evident on low-relief upland surfaces in the northern Portland Hills all indicate a prolonged period of weathering and modest erosion after eruption of the CRBG.

\section{Basaltic Eruptions of the Boring Volcanic Field (2.7-0.1 Ma)}

Starting about 2.7 Ma, basalt and basaltic andesite lavas of the Boring Volcanic Field erupted from widely scattered vents (fig. 20) (Conrey and others, 1996a; Evarts and others, 2009a). Named for the town of Boring, Oregon (Treasher, 1942), the flows erupted

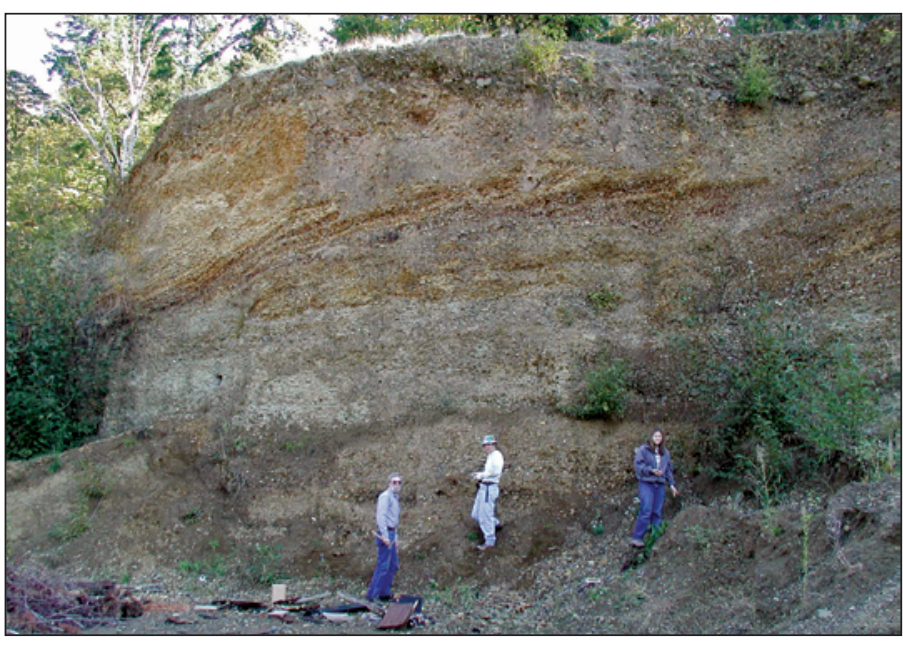

Figure 19. Photograph of fluvial cobble gravel of Columbia River source (QTcr), exposed along the railroad tracks west of Ridgefield, Washington. Gravel contains clasts of pre-Cambrian quartzite derived from the Belt Supergroup of eastern Washington, Idaho, and Canada.

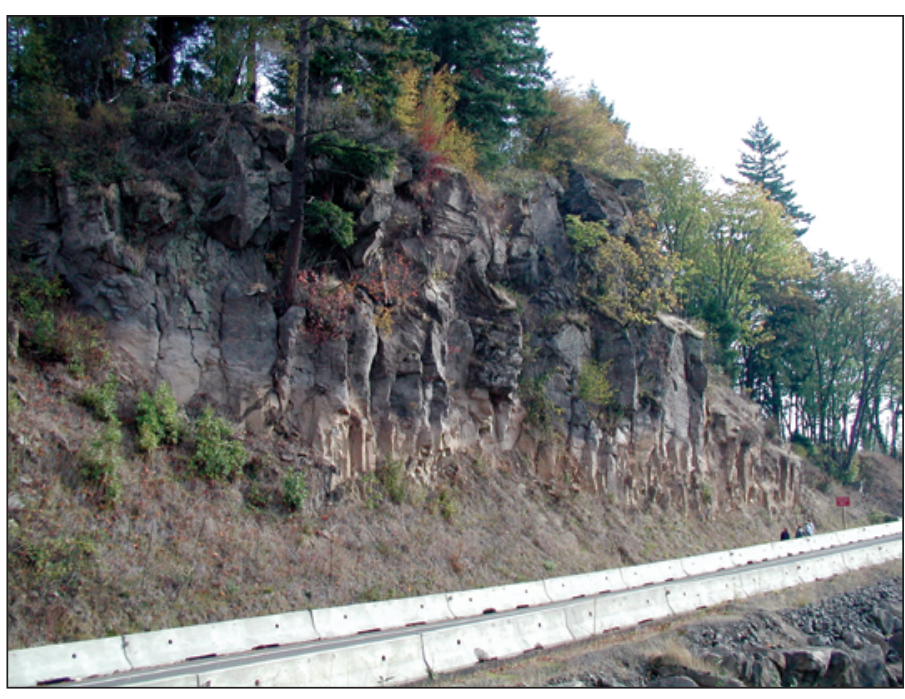

Figure 20. Photograph of approximately 0.7-m.y. columnar jointed basaltic andesite flow of the Quaternary Boring Volcanic Field (QTb4) at Prune Hill, Washington, along Highway 14.

from monogenetic cones on the west flank of the Cascade Arc and in the eastern Tualatin, northern Willamette, and southeastern Portland Basins (Trimble, 1963; Allen, 1975). In the Damascus area, the lavas punched up through unconsolidated sediments, deforming them into tilt blocks around the vents (Madin, 1994). Geophysical surveys and water-well logs suggest that other probable vents appear completely mantled by Quaternary sediment, and some vents in the path of the Pleistocene cataclysmic Missoula floods, such as Rocky Butte, were stripped of their cinder-cone carapace. Construction of the TriMet Light Rail tunnel through the Portland Hills exposed a cross section of a 1-m.y. Boring cinder cone built on the west flank of the Portland Hills and subsequently faulted and tilted westward by growth of the Portland Hills Anticline (Walsh and others, 2011). 
Beeson and others (1989a) suggested the Boring lavas erupted into extensional pull-apart basins during right-lateral motion on northwest-trending faults such as the Gales Creek and Portland Hills Faults. Evarts and others (2009a) showed that some of the basaltic compositions resemble MORB, consistent with rifting. Fleck and others (2014) found that the Boring vents become younger to the northwest across the region. They mapped the progression of the volcanic front and demonstrated that it rotated clockwise as it migrated northwest across the map area at about $9 \mathrm{~mm} / \mathrm{yr}$, approximately matching the northwest motion and clockwise rotation of the Oregon Coast Range block determined from GPS velocities (McCaffrey and others, 2007, 2013). Fleck and others (2014) suggested that extension on the trailing edge of the rotating block could have provided pathways for the lavas.

In this map, rocks of the Boring Volcanic Field are grouped into six age classes proposed by Fleck and others (2014), based on their extensive ${ }^{40} \mathrm{Ar} /{ }^{39} \mathrm{Ar}$ dating: QTb1 (2.7-2.1 Ma), QTb2 (2.1-1.3 Ma), QTb3 (1.3-0.9 Ma), QTb4 (900-450 ka; ka, thousand years before present), QTb5 (450-200 ka), and QTb6 (200-90 ka). East of the map area, rocks of the Boring Volcanic Field are as young as $55 \mathrm{ka}$ at Beacon Rock, Washington, in the Columbia Gorge (Fleck and others, 2014).

\section{Glaciation, Volcanic Eruptions, and Cataclysmic Floods (800-12 ka)}

The Pleistocene history of the metro area is dominated by deposits from glaciation in the Cascade Range, volcanic eruptions from Mount St. Helens and Mount Hood, repeated entrenchment and filling of the Columbia River valley in response to global sealevel fluctuations, and catastrophic outburst floods from Pleistocene glacial Lake Missoula that flowed down the Columbia River.

Local ice sheets and valley glaciers derived from the southern Washington Cascade Range deposited till and outwash in a broad swath trending westward to the Columbia River in the northeast quadrant of the map area. The discussion that follows is largely derived from Evarts (2005), Clynne and others (2008), and Evarts and others (2013). The oldest glacial deposits (Qgo) are well-sorted volcanic cobble gravel of Lewis River provenance that unconformably overlies quartzite-volcanic cobble-bearing Troutdale Formation ( $\mathrm{Tt})$ to elevations near $600 \mathrm{ft}(180 \mathrm{~m})$ in the Deer Island quadrangle, approximately $4 \mathrm{~km}$ north of Woodland, Washington. Its age is unknown, but it is higher in elevation than the drift of Mason Creek (Qgm), a deeply weathered, reddishbrown cobbly till and semi-consolidated gravel, sand, and silt outwash as much as $30 \mathrm{~m}$ thick derived from the adjacent Cascade Range. The drift of Mason Creek is estimated to be 600-300 ka (Colman and Pierce, 1986; Dethier, 1988), plausibly associated with one of the globally extensive glaciations of Marine Isotope Stage 16 (terminating about 631 ka per Dean and others, 2015) or Stage 14 (terminating about 424 ka per Cohen and Gibbard, 2011). Its outwash forms high terrace remnants in the valleys of Cedar Creek and Lewis River. The hills behind Battle Ground Lake may be eroded remnants of the Mason Creek end moraine.

The most widespread glacial deposits in the map area are those of the Amboy Drift (Qga) (Evarts, 2005; Evarts and others, 2003). It consists mostly of massive till and poorly consolidated sand, pebble, and cobble-gravel outwash. Till mantles upland areas south of Mount St. Helens and locally rests on glacially smoothed and striated bedrock. Outwash along the Lewis River is more than $42 \mathrm{~m}$ thick near Yacolt. The drift is composed of volcanic rocks from the western Cascade Range but locally contains light-colored clasts of coarsely porphyritic quartz-, cummingtonite-, and biotitebearing dacite derived from the ancestral Mount St. Helens volcanic center north of Lake Merwin, Washington (Crandell, 1987). Based on weathering characteristics, the Amboy Drift is correlative with Hayden Creek Drift, which Crandell and Miller (1974) interpreted to be the product of the penultimate glaciation in the Washington Cascade Range. The large apparent age range of the drift, based on ${ }^{40} \mathrm{Ar} /{ }^{39} \mathrm{Ar}$ ages of contemporaneous volcanic rocks (Evarts and others, 2003, 2004a; Clynne and others, 2008), suggests it may have been deposited during multiple glacial advances, plausibly associated with Marine Isotope Stages 10, 8, or 6, which had termination ages of $337 \mathrm{ka}, 243 \mathrm{ka}$, or $130 \mathrm{ka}$, respectively (Cohen and Gibbard, 2011).

Mount St. Helens-derived deposits in the map area document four episodes of Pleistocene and Holocene volcanic activity that in part overlap with the episodes of glaciation. The oldest such deposits were emplaced during the Ape Canyon eruptive period of Crandell (1987) (Qsa), which lasted from about $300 \mathrm{ka}$ to $35 \mathrm{ka}$, with a pronounced hiatus from 250 to $160 \mathrm{ka}$ (Clynne and others, 2008). Ape Canyon deposits consist of alluvium, lahar deposits, minor tephra, and varved, lacustrine silt and clay containing quartz + biotite \pm cummingtonite-phyric dacitic clasts derived from the Mount St. Helens volcanic center during the Ape Canyon eruptive stage of Crandell (1987). Tephra from Ape Canyon deposits (identified as "tephra C") has yielded calibrated radiocarbon ages of 47 and $49.5 \mathrm{ka}$ (Clynne and others, 2008). Compositionally similar tephra correlated with $\mathrm{C}$ tephras that underlie Amboy Drift have $\mathrm{a}^{40} \mathrm{Ar} /{ }^{39} \mathrm{Ar}$ age of $247 \pm 12 \mathrm{ka}$ (Clynne and others, 2008; reported as $250 \pm 36$ ka by Evarts, 2005). Clasts of Ape Canyon dacite have been found in poorly sorted gravel west of the Columbia River (Evarts, 2004c), indicating that at least one huge lahar moved down the Lewis River valley during Ape Canyon time, enteringand possibly temporarily blocking - the Columbia River.

Deposits of the Cougar eruptive episode (Qsc) range from 28 to $18 \mathrm{ka}$ (Clynne and others, 2008). They consist of poorly sorted pebbly to bouldery lahar and lahar-runout deposits containing clasts of light-colored, coarsely porphyritic, hornblendecummingtonite dacite; hypersthene-hornblende dacite; and reworked quartz-biotite dacite from Ape Canyon deposits that are interbedded with alluvium along the Lewis River. Tephras $\mathrm{M}$ and $\mathrm{K}$ were erupted during the Cougar eruptive stage.

Deposits of the Swift Creek eruptive episode (Qss) were erupted between 16 and $12.8 \mathrm{ka}$ (Clynne and others, 2008). They consist of material reworked from major debris fans emplaced during dacite dome eruptions on the main edifice. In the map area, deposits consist chiefly of alluvium but include fine-grained lahar and lahar-runout deposits in the Swift Creek drainage, downstream from the Swift Creek fan on the south side of the mountain. Clasts of hypersthene-hornblende dacite indicate deposition from a proto-Mount St. Helens source. Widespread tephra sets S and J were erupted during the Swift Creek stage: $\mathrm{S}$ before the dome emplacement at about $16 \mathrm{ka}$ and $\mathrm{J}$ after emplacement at about $14 \mathrm{ka}$ (Clynne and others, 2008). 
The youngest Mount St. Helens-derived deposits mapped herein are pumiceous sand and gravel along the Lewis River. Upstream of Woodland these deposits underlie low terraces; downstream they form an extensive low-elevation surface and are locally interbedded with Columbia River floodplain deposits. Geochemistry and radiocarbon ages show these sediments were mainly deposited during and shortly after the Pine Creek (2.9-2.6 ka) and Kalama (C.E. 1479-1720) eruptive periods (Vogel, 2005; Clynne and others, 2008).

Mount Hood-derived deposits of Pleistocene age occur along the Sandy River in the southeast quadrant of the map area (Evarts and others, 2013). The oldest deposits (Qh1) consist of weathered sandy gravel, silty sand, and bouldery debris as thick as $35 \mathrm{~m}$ that underlie tall dissected benches along the Sandy River as high as $540-\mathrm{ft}(165-\mathrm{m})$ elevation. Beds contain clasts of Cascadian andesites, CRBG, and sparse quartzite (probably eroded from Troutdale Formation). Some clasts are deeply weathered and easily cut by a shovel. The unit was deposited during aggradational episodes of the ancestral Sandy River, likely during glacial ages. Optically stimulated luminescence (OSL) ages show deposition between $>155 \mathrm{ka}$ and $22.4 \pm 2.5 \mathrm{ka}$ (table 2). Interbedded lahars containing Mount Hood andesite clasts indicate contemporaneous eruptive activity at Mount Hood (Pierson and others, 2010).

During the last continental glaciation, dozens of cataclysmic outburst floods from glacial Lake Missoula and other sources flowed down the Columbia River and back-flooded into the Willamette Valley and Tualatin Basins, repeatedly inundating the lowlands of the metro area to heights as much as $120 \mathrm{~m}(400 \mathrm{ft})$ above sea level (Bretz, 1925, 1959, 1969; Trimble, 1963; Glenn, 1965; Allison, 1978; Waitt, 1980, 1985, 1996; Baker and Bunker, 1985; O'Connor and Baker, 1992; Smith, 1993; O'Connor and others, 2001; O'Connor and Benito, 2009; Allen and others, 2009). Radiocarbon dating, tephrochronology, OSL ages, and stratigraphic relations indicate that the floods occurred between 20 and $\sim 15 \mathrm{ka}$ (age in calendar years; O'Connor and Benito, 2009; Waitt, 2016; see also table 2). Similar floods probably occurred during earlier continental glaciations, but their deposits have not been recognized in the metro area.

Where the floods exited the Columbia Gorge, they deposited bouldery, cobbly, sandy expansion bars (Qfc) into the Portland Basin (fig. 21A). These gravel bars are tens of meters thick and cover the eastern Portland Basin with multiple surfaces locally separated by flood channels (Allen and others, 2009). They have been extensively quarried for aggregate. Some clasts have diameters exceeding $2 \mathrm{~m}(6 \mathrm{ft})$. Similar bars were produced in the Tualatin and northern Willamette Basins as the floods flowed through the Lake Oswego, Oregon City, and Rock Creek gaps. Many of these locations have also been quarried for aggregate. Elsewhere where floodwater velocities were slower, the flood deposits consist of rhythmically stratified clay, silt, sand, and minor gravel (Qf). These slackwater deposits are widespread beneath Portland valley and Tualatin and Willamette Valley floors (fig. 21B) and extend up backflooded valleys such as the Sandy, Washougal, Willamette, and Lewis River valleys, where they mantle older terraces and valley sides with silt up to an elevation of $120 \mathrm{~m}$ (400 ft). Where the deposits exceed a few meters thickness, they form an undulating low-relief surface. In places, exotic granitic and metamorphic boulders were ice-rafted by the floods into the Portland Basin then
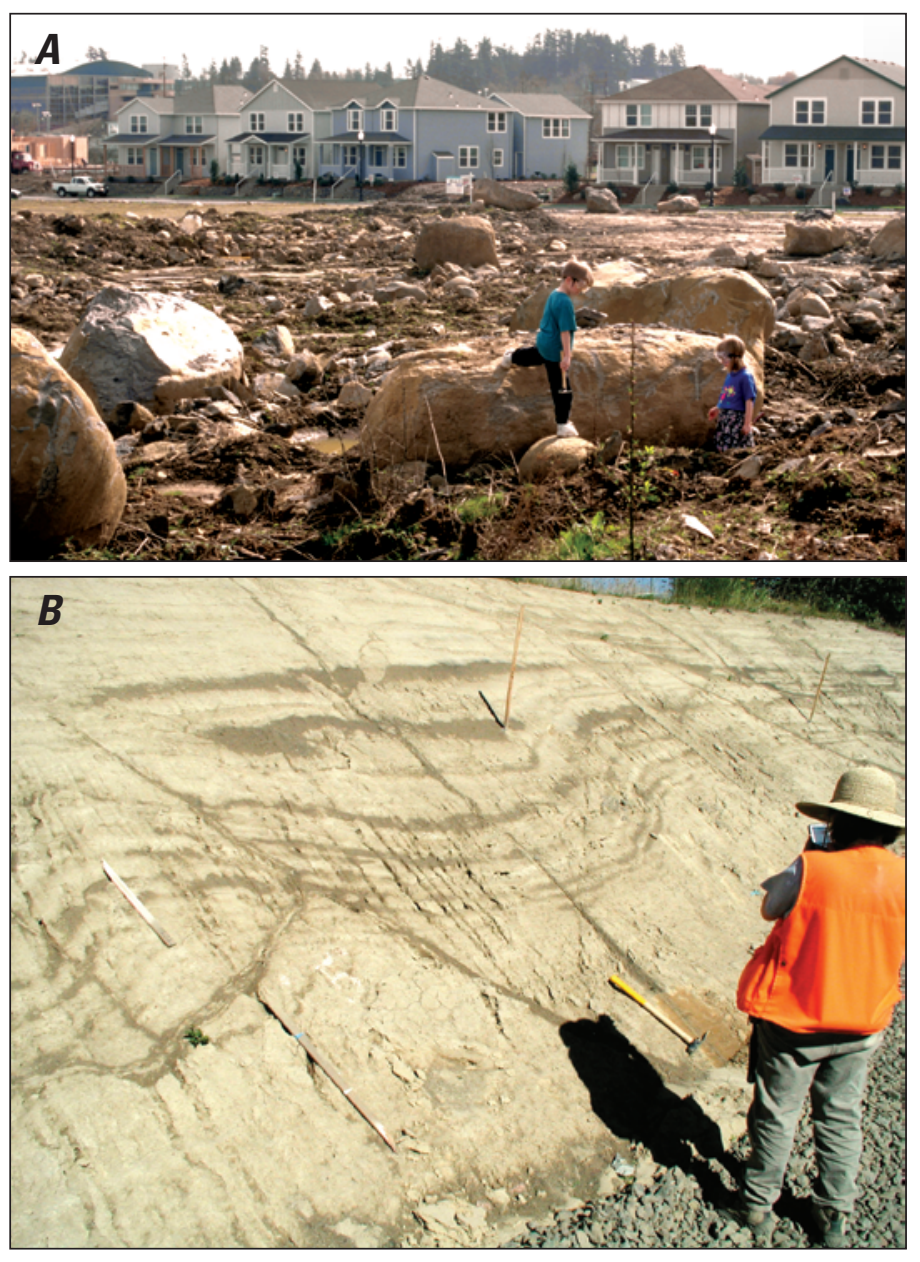

Figure 21. A. Photograph of large boulders as much as $2 \mathrm{~m}$ across in a coarse-grained fan delta (Qfc) deposited by Missoula flood waters exiting the Columbia Gorge at Troutdale. B. Photograph of more than 25 rhythmically bedded, fine sand and silt beds of the Missoula flood deposits (Qf) temporarily exposed in a road cut on Highway 26 at Cornell Road. Beds are deformed and injected by liquefaction dikes of similar material. Beds dip gently north toward nearby stream, and beds on the opposite stream bank also dip towards the stream, suggesting that the flood beds drape pre-existing topography. The deformation may reflect slumping downslope toward the stream.

beached and stranded at elevations up to $120 \mathrm{~m}$ ( $400 \mathrm{ft}$ ). Missoula flood deposits are as much as $35 \mathrm{~m}$ thick in the northern Willamette Valley and thin to less than $1 \mathrm{~m}$ at elevations above about $100 \mathrm{~m}$. The draping of multiple flood deposits over old topography was visible during reconstruction of the Cornell Road exit on Highway 26 in the Tualatin Valley, where 26 rhythmites exposed on both sides of Willow Creek dip gently into the valley.

Loess (Ql) was deposited by strong east winds blowing down the Columbia Gorge during glacial episodes. The loess consists of massive, micaceous, quartzofeldspathic silt and very fine sand forming a widespread mantle on uplands (Lentz, 1981; Lawes, 1997). To depict the bedrock geology, we have not shown the full loess extent, which is ubiquitous west of the Gorge. Thickness decreases westward from $40 \mathrm{~m}$ in the Portland Hills to a meter or less in the Coast Range (Lawes, 1997). The upper few meters is 
pale gray to tan silt, commonly overlying firm, red-brown silt with pisolitic iron-oxide concretions forming the lower part of the loess mantle. Some young loess may be windblown Missoula flood deposits, whereas other loess may be as old as early Pleistocene. Older loess appears to be interbedded with 1.1-Ma lavas of the Boring Volcanic Field in the Portland Hills (Walsh and others, 2011). West of Portland, gray loess overlies thick, dark-red lateritic paleosols developed on Columbia River Basalt flows, Paleogene strata, and older loess (fig. 22). OSL ages on the upper part of the loess at Cornelius Pass northwest of Portland range from $>79 \mathrm{ka}$ in brownish-red loess to $37 \mathrm{ka}$ in tan loess about $1.9 \mathrm{~m}$ below the surface (table 2).

\section{The Modern Landscape (14 ka-present)}

Following the last glaciation and the resulting 113-m (370$\mathrm{ft}$ ) rise in local sea level (Baker and others, 2010), the Columbia River and its major tributaries have aggraded to their present elevations, filling low-stand entrenched valleys with over $100 \mathrm{~m}$ of sand and silt (Peterson and others, 2013; Evarts and others, 2013). Sea-level rise slowed markedly at about $5 \mathrm{ka}$ (Baker and others, 2010), and most of the exposed Columbia River floodplain stratigraphy is $<2.5 \mathrm{ka}$ (Evarts and others, 2009b). Tides affect the Columbia River throughout the map area as well as the lower parts of the major tributaries. Large historical spring-snowmelt floods on the Columbia River attained stages of 10-12 m (30-35 ft) above sea level in the map area, inundating and shaping much of the Columbia River floodplain (Qa).

The lower parts of the Willamette (downstream from Willamette Falls), Washougal, Sandy, and Lewis Rivers have all aggraded in conjunction with the aggrading Columbia River (fig. 23). In addition, the Clackamas River significantly aggraded (Qty) at 12-10 ka (Wampler, 2004), possibly as a

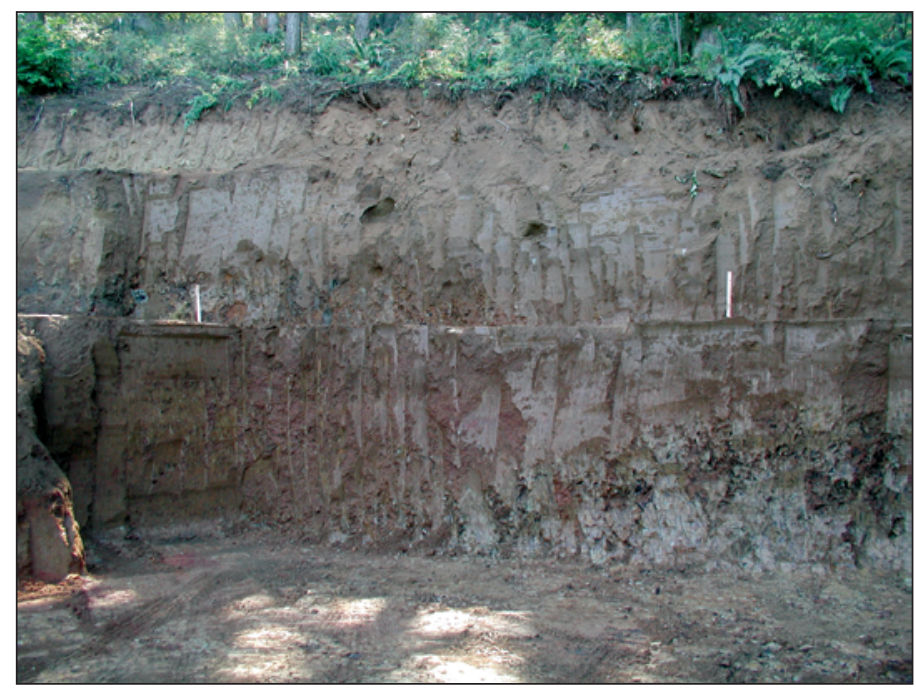

Figure 22. Photograph of windblown gray loess (QI) overlying deep red lateritic paleosol developed on weathered basalt flow of the Winter Water Member of the Columbia River Basalt Group. Photo taken near the summit of the Chehalem Mountains. Excavation is about $2 \mathrm{~m}$ deep. result of enhanced physical weathering and gravel transport in conjunction with the Younger Dryas cooling episode that apparently affected other western Cascade Range tributaries to the Willamette River (O'Connor and others, 2001). The lower Sandy River also aggraded shortly after the Missoula floods, depositing a bench (Qh2) at 160-190 ft (50-60 m) elevation near its confluence with the Columbia River, possibly as a result of blockage by a coarse-grained Missoula flood bar formed in the lee of Broughton Bluff (Evarts and O'Connor, 2008). The bench is composed of Cascade Range-provenance gravel and a Mount Hood lahar or lahar runout deposit. It lacks capping Missoula flood silt and gave an infrared stimulated luminescence (IRSL) age of $14.3 \pm 1.2 \mathrm{ka}$ (table 2).

Dune complexes $(\mathrm{Qe})$ locally stand as high as $120 \mathrm{ft}$ (35 m) above surrounding terrain north of Vancouver and $50 \mathrm{ft}$ (15 $\mathrm{m})$ above the floodplain on western Sauvie Island. Similar to the loess, these deposits were formed by easterly winds entraining Missoula flood and Columbia River deposits. They are currently inactive but are probably Holocene, judging from their weak soils and positions on top of the Missoula flood deposits and in the modern floodplain (Evarts and others, 2016; O'Connor and others, 2016). The uppermost loess (QI) is likely Holocene in some areas, particularly where close to the Columbia River.

The Sandy and Lewis River valley bottoms have been filled and expanded by volcanogenic sedimentation derived from Mount Hood and Mount St. Helens, respectively. The Sandy River delta is an extensive bottomland extending north into the Columbia River valley at the Sandy River confluence. Most of the Sandy River delta formed during the Timberline eruptive period of Mount Hood (C.E. 300-600), but is locally mantled with deposits from the Old Maid eruptive period (C.E. 1781 to about 1793; Pringle and others, 2002; Rapp, 2005; Evarts and O'Connor, 2008; Pierson and others, 2010). Together these deposits are mapped

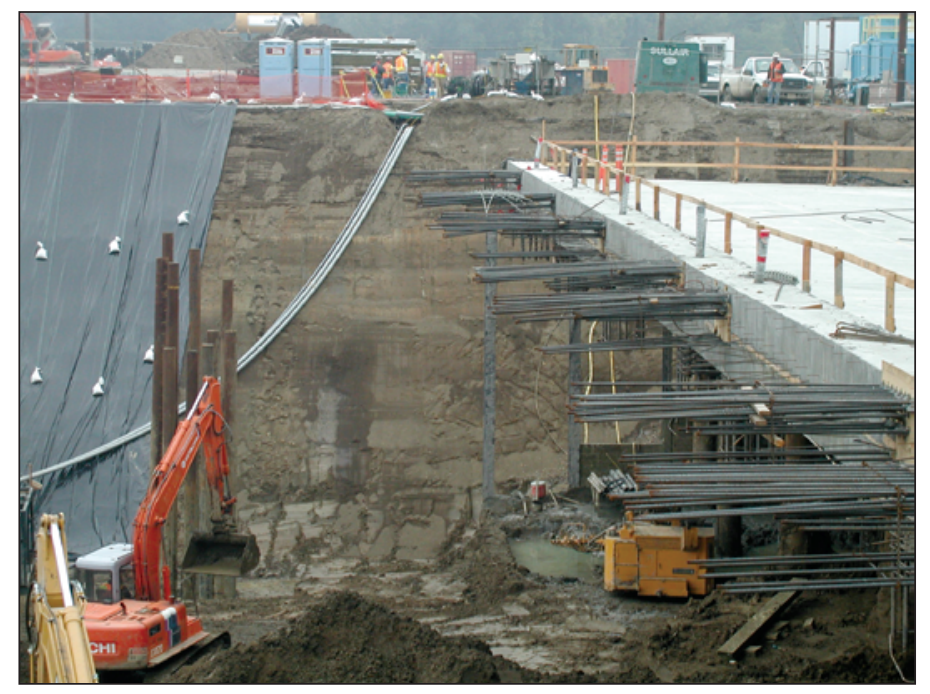

Figure 23. Photograph of horizontally bedded sand (dark brown) and mudstone (light brown) of Holocene Willamette River alluvium (Qa) exposed in construction excavation about $13 \mathrm{~m}$ deep in the South Waterfront district of Portland, about $300 \mathrm{~m}$ south of the Ross Island Bridge on the west bank of the river. 
as unit Qh3. At least three Timberline-age lahars traveled to the Columbia River (Rapp, 2005; Evarts and O’Connor, 2008). Aggradation of as much as $25 \mathrm{~m}$ of sand and gravel during the Timberline and Old Maid periods created extensive sandy terraces rising as much as $20 \mathrm{~m}$ above the current elevation of the Sandy River (fig. 24) (Pierson, 2010; Evarts and others, 2013). Aggradation from the Old Maid period was likely ongoing when observed by early explorers such as Broughton in 1792 and Lewis and Clark in 1805 (O’Connor, 2004).

Similarly, the Lewis River delta (locally known as Woodland Bottoms) is another broad bottomland occupying the joint confluence area of the Lewis and East Fork Lewis Rivers with the Columbia River. This delta developed largely in response to the 2.9-2.6 ka (Clynne and others, 2005) Pine Creek eruptive period of Mount St. Helens, which emplaced substantial sediment into the Lewis River headwaters. The central part of the delta has been channeled and partly filled with deposits from the C.E. 14791720 (Clynne and others, 2005) Kalama eruptive period of Mount St. Helens (Vogel, 2005). The decapitated Mount St. Helens on the skyline, with an occasional puff of steam, reminds us of its 1980 eruptions and continued dome building activity.

Many rivers and river reaches in the map area have been isolated from the effects of sea-level rise by bedrock obstructions such as Willamette Falls and the Portland Hills. Rivers in the Willamette and Tualatin Valleys occupy a relict lowland landscape draped by Missoula flood deposits. Pleistocene (Qto) and Holocene (Qtd, Qty) flood river terraces are locally mapped along modern rivers, as are lacustrine deposits (Qla). The Nehalem River in the Coast Range is an incised, antecedent river that is, in part, structurally controlled by the Nehalem graben. Along the upper Nehalem River, four river-terrace levels are recognized (Niem and others, 1994). The terrace deposits consist largely of rounded cobbles and pebbles of Miocene Columbia River Basalt and Eocene Coast Range volcanic rocks, with volcanic feldspathic sand, silt, and clay overbank floodplain deposits.

Landslides (QIs) and debris flow deposits (Qaf) are common in the soft sedimentary deposits and interbedded lavas of

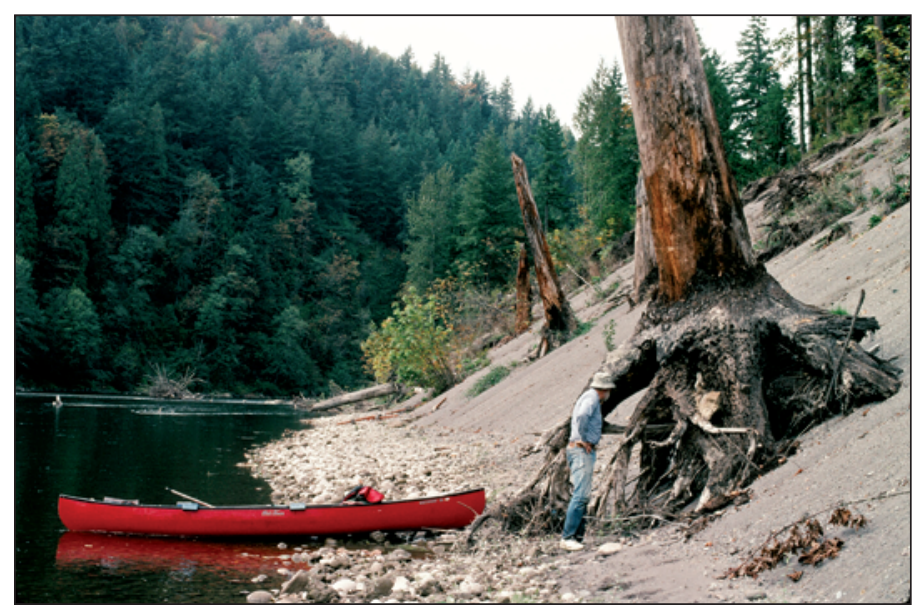

Figure 24. Photograph of tree stumps along the Sandy River at Camp Angelos that were buried by runout lahars of the 1790 eruption of Mount Hood (Qh3). the Portland metropolitan area. In the last major rainfall event, in 1996-97, thousands of slides were recorded in the greater metro area (Hoffmeister, 2000). Only larger landslides are shown on this map. The DOGAMI Landslide Database (https:// www.oregongeology.org/slido/index.htm) is the definitive catalog of landslides and debris-flow deposits for the region. Locally, colluvium (Qcb) and talus (Qt) are widespread and mapped separately from landslides. The largest landslides occur where soft sedimentary rock is overlain by lava flows, particularly the flows of the CRBG around the Tualatin Basin and on the east flank of the Coast Range (northwest map quadrant), where landslides locally form 30-40 percent of the land surface (fig. 25A,B). These landslides form mega-landslide complexes covering hundreds of square kilometers and include the Chehalem Mountains complex, which extends $26 \mathrm{~km}$ northwest from Parrett Mountain to beyond Laurelwood, the Dutch Canyon complex west of Scappoose, and the East Fork Dairy Creek complex. These complexes have long histories that may extend into the early Pleistocene (Qlso), with Holocene and active slides inset into large, older slides. Older slides are of varying ages, as shown by varying thickness of loess blanket on the slides and locally overlapping Missoula flood deposits.

Where of sufficient size, artificial fill, modified land, road grades, dikes, and levees are mapped in urban and suburban areas (af). Some abandoned logging roads and railroad grades in the Coast Range (northwest map quadrant) contain scattered rounded gravel clasts of extra-basinal quartzite and granitic and metamorphic rocks from artificial fill placed in the early 1900 s and late $1800 \mathrm{~s}$.

\section{Faulting and Active Tectonics}

The metro area lies within the Coastal Lowland, a seismically and volcanically active crustal downwarp overlying the Cascadia Subduction Zone. The lowland, which is the southern on-land extension of the Salish Sea in Washington and British Columbia (Haugerud, 2004), hosts an urban corridor that contains most of the Pacific Northwest's population. Although the urban corridor is subject to shaking from great subductionzone earthquakes offshore (Atwater and others, 2015), it is also affected by earthquakes in the deep slab and on shallow crustal faults in the lowland (http://www.pnsn.org/earthquakes/recent). The lowland has subsided in post-CRBG time ( 15 Ma), because originally subaerial CRBG flows are as much as 400 $\mathrm{m}(1,300 \mathrm{ft})$ below present sea level in the basins (see mapped contours on top of CRBG). Wilson (1997) has documented a magnetic reversal at about $150 \mathrm{~m}(492 \mathrm{ft})$ depth in the Tualatin Basin, which he interprets to be the Brunhes-Matuyama reversal at $780 \mathrm{ka}$. Using that date and its correlation with the Stage 19c highstand (Cohen and Gibbard, 2011), the resulting subsidence rate of the Tualatin Basin is $0.19 \mathrm{~mm} / \mathrm{yr}$, similar in magnitude to uplift rates for the Coast Range determined from Pleistocene terraces along the Pacific coast (Kelsey and others, 1994). The subsidence of the modern Puget-Willamette coastal trough may reflect downward transport of underlying mantle material by the subducting plate as it dives beneath North America. Mineralogic changes in the subducting crust may also contribute to earthquakes in the subducting plate about $50 \mathrm{~km}$ beneath the 

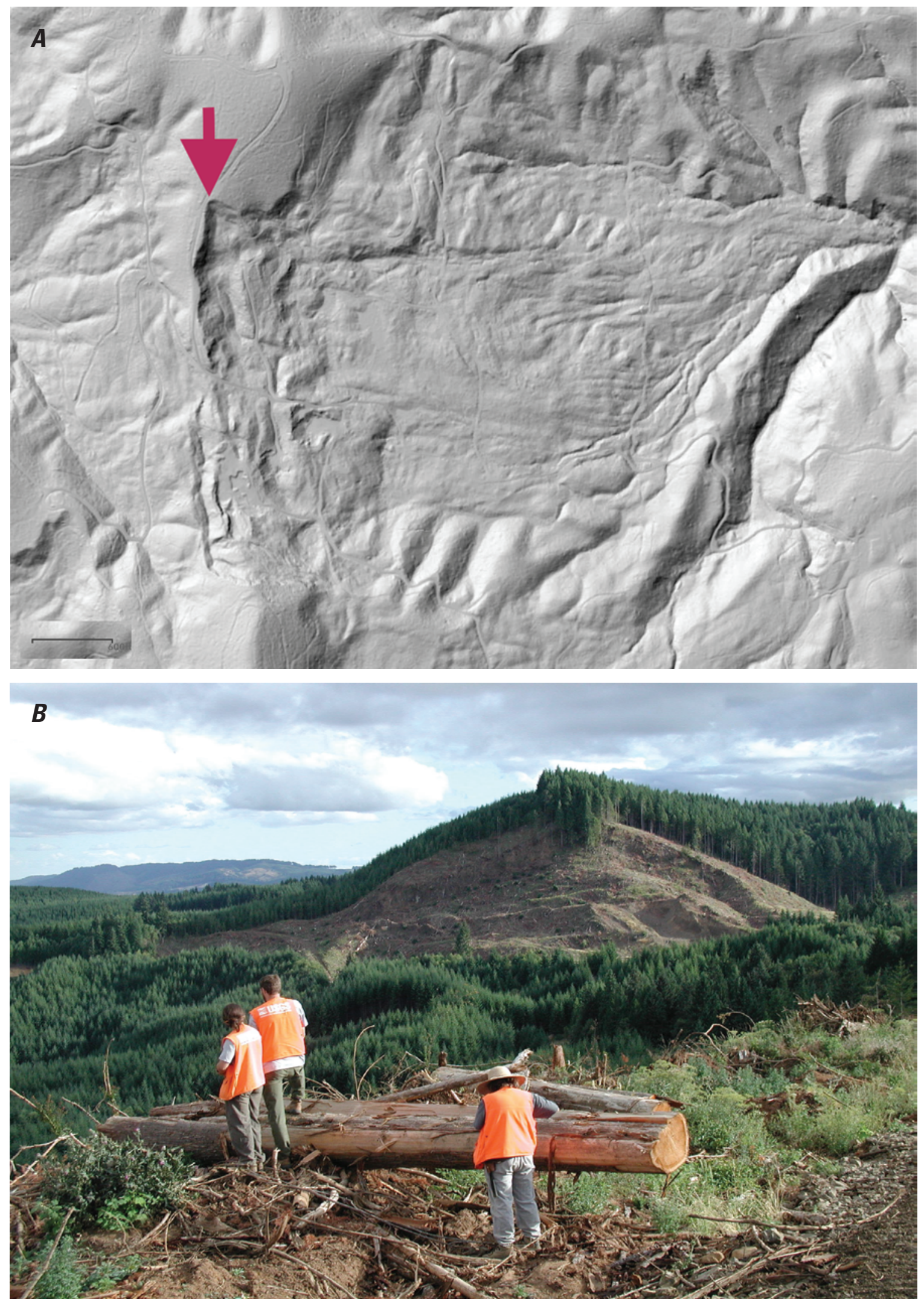

Figure 25. A. Lidar image of a large landslide of Grande Ronde Basalt of the Columbia River Basalt Group on the north flank of Wildcat Mountain about $5 \mathrm{~km}$ east of Glenwood, Oregon. Basalt overlies marine sedimentary strata of the Scappoose Formation that dip gently east, and the slide is moving eastward as deep-seated tilted blocks and shallow earthflows. The slide headscarp has crossed the drainage divide and has offset the ridge crest down to the east, resulting in a new divide about $200 \mathrm{~m}$ west of the original divide. Arrow shows view direction of photo in $B$. $B$, Photograph looking south along axis of former divide at lateral scarp cutting across and offsetting ridge crest. 
metro area (Rogers and Crosson, 2002; Kirby and others, 2002). In contrast, the Coast Range may be uplifted by coupling with the relatively young, hot, and thus more buoyant Juan de Fuca plate entering the subduction zone (Kelsey and others, 1994). GPS velocities indicate the Coast Range is presently moving northeastward and shortening, a result of coupling with the obliquely subducting plate (McCaffrey and others, 2007, 2013). Most of the eastward shortening likely will rebound during the next great subduction zone earthquake, when the Coast Range will jump westward several meters. However, a small part of the shortening $(<10$ percent?) in each subduction zone earthquake cycle may be permanent and contribute to uplift and faulting of the broad uplift that is the Coast Range (Walker and Macleod, 1991; Ma and others, 2009). The axis of the Coast Range, the Nehalem arch, plunges northeast across the northwest quadrant of the map, where Eocene and Oligocene sedimentary rock units and CRBG lava flows dip to the northeast and northwest away from the anticlinal axis (Niem and Niem, 1985; this map).

The Cascadia convergent margin is more than $1,000 \mathrm{~km}$ long, yet the margin and the Juan de Fuca plate are encompassed by the much larger transform boundary between the North America and Pacific plates. Northwest motion of the Pacific plate with respect to North America at about $51 \mathrm{~mm} / \mathrm{yr}$ applies a component of right-lateral motion to the subducting plate and the overlying Pacific Northwest, causing the Cascadia margin to break up into smaller, clockwise rotating blocks (fig. 3, Beck, 1976; Magill and others, 1982; Wilson, 1993; Pezzopane and Weldon, 1993; Walcott, 1993; Wells and others, 1998; McCaffrey and others, 2007, 2013). The Oregon Coastal block is migrating northward as it rotates clockwise at about $1 \%$ Ma around a pole in the back arc. This causes north-south shortening between Portland and the Canadian border at about $7 \mathrm{~mm} / \mathrm{yr}$ (McCaffrey and others, 2007, 2013). This deformation is superimposed on the overall subsidence of the Coastal Lowland, producing the Portland Hills, Parrett Mountain, and Chehalem Mountains uplifts that separate the Portland, Tualatin, and Northern Willamette Basins.

Some of the northward motion is accommodated by distributed right-lateral shear on northwest-trending faults in the map area (fig. 3). The Gales Creek Fault Zone offsets an anticline in the Siletz River Volcanics about $12 \mathrm{~km}$ in a right-lateral sense just west of Gales Creek. Paleogene strata near Scoggins Dam show similar separation, whereas the axis of the southeast-dipping monocline of CRBG forming the Red Hills of Dundee appears to be separated from the Parrett Mountain monocline about 6-8 km in a right-lateral sense near Newberg (southwest map quadrant). The long-term $(\sim 15 \mathrm{Ma})$ dextral-slip rate from these geologic offsets is about $0.6 \mathrm{~mm} / \mathrm{yr}$. The 1993 Scotts Mills, Oregon, M 5.7 earthquake had an oblique right-lateral thrust focal mechanism and was inferred to occur on the Mount Angel Fault, an extension of the Gales Creek Fault Zone south of the map area (Thomas and others, 1996). It caused regional strong shaking and \$25M in damage (Madin and others, 1993). West- to northwest-trending faults are inferred to underlie the southern Tualatin Basin between the Gales Creek Fault and the Portland Hills Fault Systems based on water-well data (see subsurface contours on top of CRBG in the Tualatin Basin on map). Several left-stepping offsets in the Gales Creek Fault Zone appear to coincide with N. 60-70 W. left-lateral faults in the Coast Range that terminate at the
Gales Creek Fault (southwest quadrant of map). These faults are apparently Riedel shears or "bookshelf" faults that accommodate clockwise rotation of crustal blocks above the subduction zone (see Freund, 1974; Wells and Coe, 1985).

Quaternary offsets have been suspected for several fault zones in the Portland metropolitan area (U.S. Geological Survey, http://earthquake.usgs.gov/hazards/qfaults/), and the region is seismically active (Bott and Wong, 1993; Yelin and Patton, 1991). However, unequivocal evidence of fault scarps produced by large, surface-rupturing earthquakes after the Missoula floods (since $\sim 15 \mathrm{ka}$ ) is rare. This may reflect the urban cover and relatively low slip rates on crustal faults in the map area. The major exception is along the Gales Creek Fault along the western margin of the map area. We summarize here observations that confirm Quaternary deformation on several structures. The Sylvan-Oatfield Fault, part of the Portland Hills Fault system, $1 \mathrm{~km}$ from the west portal of the TriMet Light Rail tunnel, thrusts CRBG on top of a 1-Ma Boring flow, with an average vertical slip rate of 0.15 to $0.24 \mathrm{~mm} / \mathrm{yr}$ (the horizontal slip rate is unknown, Walsh and others, 2011); a splay of the fault appears to deform the 120-ka Boring flow that forms the west portal of the TriMet Light Rail tunnel. The Portland Hills Fault (Balsillie and Benson, 1971) deformed and liquefied Pleistocene Missoula flood deposits at North Clackamas Park (Wong and others, 2001). Possible offsets in Pleistocene strata of the Portland Basin have been recognized by Pratt and others (2001) and Liberty and others (2003). The Bolton Fault in the Oregon City quadrangle offsets the $2.4 \mathrm{Ma}$ Boring flow $28 \mathrm{~m}$, yielding a vertical slip rate of $0.011 \mathrm{~mm} / \mathrm{yr}$ (Madin, 2009). The Damascus Faults form a reticulated pattern of short faults localized around Quaternary vents of the Boring Volcanic Field (Madin, 1994). The Gales Creek Fault Zone (GCFZ), forming the boundary between the Coast Range and the Tualatin Basin, offsets most of the crossing streams a kilometer or more in a right-lateral sense between Newberg and Timber (Wells and others, 2020). Three kilometers east of the town of Yamhill, a thrust splay of the GCFZ places mudstone of the Eocene Yamhill Formation ( $45 \mathrm{Ma}$ ) over silt (old loess?) with an OSL age of $250 \mathrm{ka}$ (Wells and others, 2020). Redwine and others (2017) have documented surface rupture along the Gales Creek Fault of flood plain deposits of presumably late Holocene age near Henry Hagg Lake. Quaternary subsidence of the Tualatin Basin at $0.19 \mathrm{~mm} /$ yr since $780 \mathrm{ka}$ (Wilson, 1998) and 0.2-0.9 mm/yr uplift inferred from Quaternary river incision rates in the northern Coast Range (Personius, 1995) suggest a young vertical component to Gales Creek Fault displacement that is consistent with $>5 \mathrm{~km}$ offset of the Siletzia basement determined from gravity data (McPhee and others, 2014).

\section{Earth Resources}

Although this map was created to improve our understanding of geologic hazards, we hope that it will also lead to improved understanding of the region's earth resources. The metro area has abundant water, land suitable for high-value agriculture and forestry, construction aggregate, and modest amounts of natural gas. Parts of the area were prospected for bauxite, and small residual deposits of iron ore are associated 
with the CRBG. The geology of the metro area also provides ideal underground reservoirs for storing water and natural gas for use during times of seasonal high demand.

\section{Groundwater}

Gannett and Caldwell (1998), Woodward and others (1998), McFarland and Morgan (1996), and Conlon and others (2005) summarized the hydrogeologic framework of the Willamette Valley and defined three main aquifer systems and their confining units: (1) an upper, unconfined alluvial unit (Qa and related units on the map) overlying a widespread silt confining unit, the Willamette Silt deposited by the Missoula floods (Qf on the map); (2) Pliocene-Pleistocene sands and gravels beneath the silt and overlying a Miocene confining unit of floodplain silt (Qa, QTcr, Ttc and related units); and (3) the Columbia River Basalt aquifer sandwiched beneath the Miocene silts and a low permeability basement of older volcanic and sedimentary rocks of the Coast Range and the western Cascades.

The well field near the Portland International Airport taps the upper unconfined aquifer and underlying Pleistocene sands and gravels along the Columbia River. It provides as much as 150 million gallons/day to Portland as an auxiliary water source (Hoffstetter, 1984).

The CRBG is host to a regional aquifer system that underlies the Columbia Plateau and extends into the Willamette Valley (Tolan and others, 2009; Gannett and Caldwell, 1998). This regionally extensive, thick lava-flow sequence contains water stored in the interflow breccia zones, which consist of the vesicular flow-top breccia and the basal breccia of the overlying flow. Sedimentary interbeds between flows are commonly lacking or discontinuous. Dense flow interiors act as confining units, and the resulting aquifer typically consists of a stack of water-bearing horizons with lateral continuity and low vertical permeability. In the map area, groundwater from the CRBG is used for agriculture and for domestic water supplies and hosts Aquifer Storage and Recovery systems (ASR), which store drinking water in the basalt for the dry summer months. In the Tualatin Basin, the CRBG hosts an extensive multi-layered aquifer system that is used for ASR by the cities of Beaverton, Tigard, and Tualatin (Burt and others, 2009).

\section{Aggregate}

Aggregate consists of sand, gravel, and crushed stone used for construction of buildings, roads, and other infrastructure. The metro area is the major consumer of aggregate resources in the state, and the Willamette River Basin accounts for 60 to 65 percent of the commercially mined aggregate in Oregon (Achterman and others, 2005). Whelan (1995) reports "a typical Oregonian's "share" of aggregate use in the state amounts to about 10 to 15 tons of sand, gravel, crushed rock, and recycled concrete and asphalt per year or about one dump truck load per person." Commercial aggregate production for Washington, Multnomah, and Yamhill Counties in Oregon was about 7,495,000 tons in 2003, which was used primarily for roads and construction (Achterman and others, 2005).
Major sources for aggregate are the gravel pits along the Columbia and Willamette Rivers, gravel pits in the flood gravels in northeast Portland and the Durham area in the Tualatin Basin, and numerous rock pits for crushed rock in the Columbia River Basalt, Boring lavas, and volcanic foothills of the Cascade Range.

The need for aggregate in the metro area is expected to continue, even as expansion of aggregate mining is constrained primarily by urban growth, high-value soils for agriculture, and habitat needs for fisheries in the major streams (Achterman and others, 2005). Indeed, numerous quarries in the metro area have been reclaimed and are now covered by housing developments (compare the Beaverton urban area today with quarry locations shown in Schlicker and Deacon, 1967).

\section{Agriculture}

Much of the area surrounding the metro area is underlain by high-value soils intensively farmed for vineyards, nurseries, grass seed, orchards, and berries. The relatively fertile soils in the valleys are derived from modern river alluvium and Missoula flood silts, whereas upland areas are underlain by soils derived from weathered volcanic parent materials and marine sedimentary rocks.

The upland areas forming the Coast Range foothills in the southwestern part of the map area are home to five internationally known American Viticultural Areas (AVAs), which produce grapes for the Oregon wine industry - the Willamette Valley, Chehalem Mountains, Ribbon Ridge, Red Hills of Dundee, and Yamhill-Carlton AVAs. Research is underway to assess the role of geology and soil in producing the "terroir," or sense of place, that characterizes each AVA (Burns, 2012; Retellack and Burns, 2016; Barnard, 2016; Wells and others, 2018).

\section{Oil and Gas}

Although 70 years of exploration for oil and gas in the Pacific Northwest had produced no commercial discoveries, Newton (1969) and Newton and Van Atta (1976) proposed that northwestern Oregon had good potential for a natural gas field. Exploration along the Nehalem arch, a structural culmination in the Nehalem Basin along the axis of the Coast Range uplift, led to discovery in 1979 of commercial quantities of natural gas at Mist, in the northwestern part of the map area (Armentrout and Suek, 1985). Production is from the Sandstone member of the Cowlitz Formation (TcCW; Clark and Wilson sand of Mist Field exploration usage), found between 2,000 and 4,000 ft depth in fault-bounded blocks on the crest of the Nehalem arch.

The Mist gas field is the only producing field in the Pacific Northwest, and it produced about 65 billion cubic $\mathrm{ft}$ of gas (BCFG) through 2008 (Oregon Department of Geology and Mineral Industries, 2009). With its location close to the Portland metropolitan area and existing pipelines, the field has become valuable as a gas-storage facility, and expansion of capacity is planned to store gas for peak power-plant demand (https://www. oregongeology.org/mlrr/oilgas-report.htm).

Overall, the current assessment is that western Oregon and Washington have low to modest hydrocarbon potential, predominantly natural gas in coalbed-methane plays (Brownfield, 2011). 


\section{Map Compilation}

The map is a visualization of the digital database SIM3443. $\mathrm{gdb}$ which is a compilation of published geologic mapping, published mapping with slight revisions, unpublished mapping, and new interpretations (see table 1 for mapping sources). Database SIM3443.gdb conforms to the GeMS schema (U.S. Geological Survey National Cooperative Geologic Mapping Program, in press; see http://ngmdb.usgs.gov/Info/standards/GeMS).

\section{Process Steps}

The process by which we compiled this map within a GIS using the GeMS schema bears on the accuracy and reliability of the map, thus we document it here. The process may also be of interest to those contemplating similar compilation efforts. Note that this process description is idealized; our work was not as linear as depicted below.

Wheeler did much of the initial work assembling source datasets, in many cases translating them from original ArcInfo.e 00 files or shapefiles into Esri geodatabases that approximated the GeMS schema (step 1). Subsequent compilation by Haugerud and Wells followed several steps:

1. Established schematic consistency among source materials. Each source dataset was reworked to a consistent arrangement of features (lines, polygons, points) in feature classes, with similar feature attributes. For lines, we added Type, IsConcealed, LocConfM, ExConf, and IdConf attributes to supplement the LTYPE (or similar) attribute present in most source databases. For polygons, we added MapUnit and IdConf attributes to supplement the PTYPE (or similar) attribute present in most source databases.

2. Established semantic consistency amongst source materials. This required translation of LTYPE (or similar attributes) into GeMS attributes; for example, LTYPE = "contact, approximate" may have become Type = "contact", LocationConfidenceMeters (estimated location accuracy) = "60", ExistenceConfidence $=$ "certain", IdentityConfidence = "certain", or similar. Values of LocationConfidenceMeters were determined based on source material scale, source-map base (for example, lidar or topo sheet), compiler's experience, and (in some cases) conversations with the source-map author. Descriptors of fold axes, key beds, and structural measurement points were translated to common sets of Type values. Values of LocationConfidenceMeters and OrientationConfidenceDegrees (estimated accuracy of orientation measurements) were assigned based on source-map scale, sourcemap feature description, and our experience. After semantic consistency was established, line and point features from the source materials were loaded into the compilation database.

For map-unit polygons, we prepared a composite Description of Map Units table for all source maps by copying and pasting from the source materials. This table-AllDMUs in OtherSources.gdb - has attributes DataSourceID (source map), SourceMapUnit, SourceUnitName, SourceIdConf,
SourceDescription, SourceAge, SourceHierarchyKey, and CompilationUnit. Study of this table disclosed numerous natural groupings: young alluvium, Wanapum Basalt, and so forth. Members of each grouping were assigned a common value of CompilationUnit. Some groupings are less obvious; parts of our compilation stratigraphy reflect extensive discussion and compromise necessary to portray a relatively coherent geologic history and honor the stratigraphic distinctions or lack thereof in the source materials. Sorting of AllDMUs by CompilationUnit allowed easy comparison of SourceUnitName and SourceDescription to validate correlations. Resorting by DataSourceID and SourceHierarchyKey facilitated checking that local stratigraphic superposition was honored.

We then assigned DataSourceID values to source-map polygons, loaded source-map polygon feature classes into the compilation database, added a temporary field "DataSourceID-SourceMapUnit" to the compilation MapUnitPolys feature class, calculated values for it, and used it to join the compilation feature class to AllDMUs (to which we added a similar temporary field). We then calculated MapUnit $=$ AllDMUs.CompilationUnit. At this point we had a preliminary compilation database with a single set of feature classes that had numerous gaps, overlaps, and mismatches at source-map boundaries and numerous internal contacts, for example, contacts between polygons with the same value of MapUnit. This database is preserved, in part, in geodatabases Tualatin.gdb and OtherSources.gdb.

3. Established topologic consistency within the compilation. The final compilation map reflects substantial editing to resolve gaps, overlaps, and mismatches. The edited map is more likely to be correct than the unedited preliminary compilation - as geologic reality is certainly continuous across source-map boundaries - and, being topologically consistent, is more susceptible to various automated analyses. To preserve feature lineage information, mostly we did not edit or extend existing ContactAndFaults lines. Rather, we digitized new line segments and deleted extraneous segments and then merged adjacent polygons with identical MapUnit values. Our editing was guided by Steno's principles (Original Horizontality, Superposition, Primary Lateral Continuity), topography, and our senses of depositional and deformational style informed by the geologic literature, our experience elsewhere, and our experience in the Portland area. For the Chapman and Trenholm quadrangles, where this map presents a hypothesis elaborated without adequate field work, we drew on sparse field notes from coauthors (Sawlan, A. Niem) and predecessors (Dibblee).

Efforts to remove internal contacts by automated means were unsatisfactory and we resorted to hand editing: selection and deletion of such contacts and selection and merging of the polygons they once separated.

4. Edited much of the map to remove too-small map-unit polygons, mostly of surficial materials. Locally, we replaced complex linework with simpler linework for presentation at 1:63,360 scale. 
5. Checked the edited database, using the GeMS Tools TopologyCheck script, for digitizing defects (dangling contact lines, self-overlapping and self-intersecting contact and fault lines, overlapping map-unit polygons, gaps between map-unit polygons, incorrect snapping at line junctions), internal contacts, concealed faults or contacts that separated polygons with different MapUnit values, improbable young faults, and other errors. Many such errors were relict from the source materials; others were introduced in the course of our editing. We remedied errors and rechecked the database until it was judged acceptable.

Where our corrections involved re-attribution of line Type (for example, change from "fault" to "normal fault"), flipping of line direction (to change the downthrown side of a fault), or minor extension of a fault (to eliminate apparent truncation by a contact that is not a younger unconformity), we retained the DataSourceID of the original line source to reflect the primacy of the geometry established by the source-map authors. We reserved DataSourceID = "W\&H" for lines with new geometries.

The database still contains a few faults that cross older features without offset and numerous concealed bedrock contacts that are exactly coincident with overlying surficialunit contacts. Both of these situations are improbable, but where preserved in this map they were present in the source materials.

Coincidence of map-unit polygon boundaries with ContactsAndFaults arcs was assured by using the GeMS_Tools MakePolygons script to rebuild MapUnitPolys from the final ContactsAndFaults feature class. Polygon attributes were taken from label points extracted from the prior MapUnitPolys feature class.

6. Assembled contours on the buried top of the CRBG (feature class IsoValueLines) from Swanson and others (1993), Conlon and others (2005), and an unpublished interpretation of well data in the Tualatin Basin by Matt Anders (USGS). Outside the Tualatin Basin, contours were evidently drawn without regard to likely fault offset; such offsets are only evident as steepening of the surface defined by the topof-CRBG contours. Within the Tualatin Basin, we have substantially revised contours (1) to better fit surface geology as depicted on this map, an expanded suite of well data, interpretations by Yeats and others (1996) of proprietary seismic reflection data, and our sense of structural style and (2) to show offsets at faults.

7. Translated feature class BoringLavaAgePoints from the data tables of Fleck and others (2014). Feature class LuminescenceAgePoints was assembled from data reported by Evarts and others $(2013,2016)$ and unpublished analyses by Shannon Mahan (USGS). Previously unpublished chemical analyses of volcanic rocks - mostly CRBG-were assembled from several sources into feature class GeochemistryPoints.

8. Checked internal logical consistency and completeness of the database with the GeMS Tools ValidateDatabase script. Table, feature class, and attribute names and formats conform to the GeMS standard. All Type values (in ContactsAndFaults, GeologicLines, and other feature classes) are defined in table Glossary. All ID values are unique. There are no empty DataSourceID (or DefinitionSourceID, or AnalysisSourceID, or ...SourceID) values, and all such values are defined in table DataSources. All intentionallynull attributes are labeled with $<$ Null $>$ (for text attributes) or -9 or -9999 (for numeric attributes); there are no empty string values. MapUnit values in feature class MapUnitPolys correspond with those defined in DescriptionOfMapUnits and shown in CorrelationOfMapUnits.

9. Prepared FGDC-DSDGM metadata with the assistance of GeMS_Tools scripts and a stand-alone version (see https:// github.com/usgs/fort-pymdwizard) of the Metadata Wizard of Ignizio and others (2014).

The draft report was reviewed by Steve Box (USGS) and Scott Burns (Portland State University). Their reviews resulted in modifications to the database and partial repetition of steps 3-8. The database and metadata were then reviewed by Pamela Cossette (USGS), who identified several deficiencies which we remedied by partial repetition of steps 3-9.

\section{Sources of Map Data}

The GeMS schema provides internal documentation of the sources of map features via DataSourceID, LocationSourceID, and similar attributes. These attribute values are explained in a DataSources table. Values of $x x x$ SourceID attributes in SIM3443. $\mathrm{gdb}$ are listed in table 4 . The authors of this report are responsible for the identity of all map-unit polygons in SIM3443.gdb, thus DataSourceID for these polygons is given as "this report". Sources of contacts and faults in SIM3443.gdb are shown on sheet 1.

Most of the source map data are replicated in unrevised, uninterpreted form in databases Tualatin.gdb and OtherSources. gdb, which are also part of this report. Note that these are not valid GeMS-format databases. Previously unpublished mapping of six 7.5' quadrangles (Birkenfeld, Pittsburg, Baker Point, Clear Creek, Vernonia, Bacona) in the northwestern part of the map was compiled into the final map database and is not reproduced elsewhere in this report.

Tualatin.gdb is 1:24,000-scale geologic map data for eleven 7.5-minute quadrangles in the Tualatin Valley area. Some small surficial-unit polygons in this geodatabase were omitted or combined for representation at a scale of 1:63,360 in SIM3443.gdb.

OtherSources.gdb is a composite of digital data from numerous sources identified in table 1. Within OtherSources.gdb, polygon attributes have not been recast for semantic consistency: polygons with MapUnit = Qa from one source may not represent the same map unit as polygons with MapUnit = Qa from another source. Other feature attributes have been recast for structural consistency, so that attributes of features from different sources may be stored in a single set of tables. Feature geometry has not been edited for topologic consistency: contacts commonly do not meet at source map boundaries and there are areas of overlap and voids where adjacent source maps overlap or do not meet. 


\section{Correlations}

Table AllDMUs, as described above, is a composite of all source-map Description Map Units tables and is included in OtherSources.gdb. This table provided a preliminary framework for map-unit correlations.

The digital materials within this report also include a Correlations table that summarizes our interpretation. It was produced by intersecting map-unit polygons from SIM3443.gdb with source map polygons from Tualatin.gdb and OtherSources.gdb and manipulating the results. The table is provided in Microsoft Excel format (Correlations.xls) and in HTML format (Correlations.html). An example of this table is shown to the right.

Note that values in the "Percent (\%) of compilation map unit" column do not, in general, sum to 100 . This largely reflects overlaps and gaps between source maps. To a lesser extent it reflects rounding of the values.

Contours on the top of the CRBG (CRBG) were compiled from several sources.

\begin{tabular}{|c|c|c|c|c|c|}
\hline \multirow{2}{*}{$\begin{array}{l}\text { Compilation } \\
\text { map unit } \\
\text { label }\end{array}$} & \multirow{2}{*}{$\begin{array}{c}\text { Aggregate } \\
\text { area }\end{array}$} & \multicolumn{3}{|c|}{ Constituent Units } & \multirow{2}{*}{$\begin{array}{c}\text { Percent }(\%) \text { o } \\
\text { compilation } \\
\text { map unit }\end{array}$} \\
\hline & & $\begin{array}{c}\text { Source- } \\
\text { Map Unit } \\
\text { label }\end{array}$ & $\begin{array}{c}\text { SourceMap Unit } \\
\text { name }\end{array}$ & $\begin{array}{l}\text { Source- } \\
\text { Map }\end{array}$ & \\
\hline \multirow[t]{4}{*}{$\mathrm{Qa}$} & $45.3 \mathrm{~km}^{2}$ & & & & \\
\hline & & Qal & Alluvium & $\mathrm{Sm} 1$ & 11.2 \\
\hline & & Qal & Alluvial deposits & $\mathrm{Sm} 2$ & 0.3 \\
\hline & & Qa & Alluvium & Sm 3 & 43.7 \\
\hline
\end{tabular}

\section{Acknowledgments}

We thank Scott Burns, Steve Box, and Pamela Cossette for helpful reviews. Craig Weaver of the Earthquake Hazards Program encouraged the creation of the map and supported its completion. Joanna Redwine of the Bureau of Reclamation provided support and comments on an early draft. We also thank Stimson Lumber and many other landowners for access to private property that was essential to completing this project.

\section{DESCRIPTION OF MAP UNITS}

\section{UNCONSOLIDATED DEPOSITS}

af Artificial fill (Holocene, Anthropocene) — Soil, sand, gravel, and rock to form elevated road and railroad beds, levees, dikes, and other filled areas

Qa Alluvium (Holocene) - Stratified clay, silt, sand, and gravel deposited along rivers and streams. Locally includes organic-rich mud in valley bottoms and poorly sorted alluvial fan deposits along valley margins

QIs Landslide deposits (Holocene and Pleistocene) - Poorly sorted angular to subrounded bedrock blocks and fragments in weathered muddy matrix. Forms lobate masses with hummocky topography and poor drainage below arcuate headscarps; locally includes colluvial aprons of angular cobbles and boulders at the base of steep slopes. Deposits have been transported downslope by deep-seated landsliding, rockslides, earthflows, and debris flows; thickness 10-40 m. Locally, some deposits mapped separately:

Qlso Older landslide deposits - Poorly sorted angular to subrounded bedrock blocks and fragments in weathered muddy matrix. Forms lobate masses with hummocky topography; slide topography and head scarps are subdued by erosion and (or) thick loess cover. Includes mega-landslide complexes southwest of Chehalem Mountains, in East Fork Dairy Creek, and in Dutch Canyon with megablocks as much as $2 \mathrm{~km}$ in length. Commonly composed of Columbia River Basalt displaced out of stratigraphic order and hosting many younger landslides

Qt Talus (Holocene and Pleistocene)-Accumulations of angular bedrock blocks below cliffs

Qaf Alluvial fan deposits (Holocene) - Poorly sorted, crudely stratified framework-supported gravel, sand, and silt deposited on valley floors at the mouths of steep tributary streams. Includes matrix-supported debris-flow deposits and colluvial aprons

Qla Lacustrine deposits (Holocene and Pleistocene) - Unconsolidated black to gray silt, mud, and organic debris; locally includes dark-brown to olive-green peat and organic-rich mud. In the Portland Basin (Lacamas Creek and Orchards quadrangles) some lacustrine deposits overlie Missoula flood deposits. Beneath bed of drained Fargher Lake (Amboy and Ariel quadrangles), unit is at least $11 \mathrm{~m}$ thick and includes peat, gyttja, and several tephra layers erupted from Mount St. Helens (Mundorff, 1964; Heusser and Heusser, 1980). Tephrochronology, radiocarbon ages, and pollen analysis indicate deposits range from at least 55,000 to about 20,000 years old (Grigg and Whitlock, 2002). In the Tualatin Basin (Gaston quadrangle), lacustrine deposits of Wapato Lake postdate Missoula floods

Qe Eolian deposits (Holocene and Pleistocene) — Unconsolidated, massive sand and silt broadly covering upland areas. Forms undulating fluted topography, locally shaped into parabolic dunes. Mapped only where undulating surfaces imply thick accumulations. Mostly quartzofeldspathic sand containing muscovite and minor lithic fragments. Likely formed by easterly winds entraining cataclysmicflood deposits and Columbia River beach and bar sand. Historically inactive but position atop cataclysmic flood deposits requires late Pleistocene or Holocene age 
Loess-Massive, micaceous, quartzofeldspathic silt and fine sand forming widespread mantle on uplands. Upper few meters is pale gray to tan, locally containing isolated granules and small pebbles; lower part of unit is firm, red-brown silt with pisolitic iron-oxide concretions. Thickness decreases westward from $40 \mathrm{~m}$ in the Portland Hills to a meter or less at west edge of map, where it is mostly not mapped. West of Portland, loess overlies thick, dark-red lateritic paleosol developed on Columbia River Basalt flows, Tertiary sedimentary rocks, and older loess. In northeast Tualatin Basin on lee side (southwest) of Portland Hills, includes V-shaped very fine-grained dunes and blowout features oriented east-west. Older loess appears to be interbedded with $\sim 1.1$ Ma lavas of the Boring Volcanic Field in the Portland Hills (Walsh and others, 2011). Loess was deposited by strong east winds blowing down the Columbia Gorge during several Pleistocene continental glacial episodes. Includes Holocene accumulations closer to the Columbia River

Qtd Terrace deposits (Holocene and Pleistocene) - Unconsolidated, stratified fluvial sand, basalt gravel, and lesser floodplain clay and silt. Forms three to five distinct benches along the bedrock-incised valleys of the Nehalem River and some other Coast Range streams

Younger terrace deposits (Holocene and Pleistocene?) - Unconsolidated, fluvial sand, gravel, lesser floodplain clay and silt forming lower terrace surfaces along streams. Radiocarbon ages in Schanz and Montgomery (2016) indicate these younger terraces are Holocene. May in part postdate late Pleistocene Missoula floods

Older terrace deposits (Pleistocene) - Unconsolidated, locally semi-consolidated, fluvial sand, gravel, lesser clay and silt on higher terrace surfaces above streams. Along Nehalem River, includes flight of strath terraces mantled with framework-supported yellow-brown to dark-gray rounded basalt gravels, largely sourced from Columbia River Basalt and (or) Eocene Tillamook and Goble Volcanics. Deposits locally include lenses of micaceous quartzofeldspathic sand, quartz pebbles, and silt; $2 \mathrm{~m}$ to $6 \mathrm{~m}$ thick. Probably largely predate late Pleistocene Missoula floods

Mount St. Helens-derived deposits (Holocene and Pleistocene) - Unconsolidated, stratified sand and gravel composed predominantly of light-colored dacitic debris from ancestral Mount St. Helens that was deposited in drainages south and west of the volcano

Youngest terrace deposits (Holocene) - Unconsolidated, stratified pumiceous sand and gravel composed of volcanic debris transported down Lewis River from Mount St. Helens, northeast of the map area. Underlies low terraces along the Lewis River and an extensive lowland along the Columbia River and west of Woodland; includes local areas of artificial fill. Deposits west of Woodland range from $10 \mathrm{ft}$ $(3 \mathrm{~m})$ to $30 \mathrm{ft}(10 \mathrm{~m})$ in elevation and are locally interbedded with Columbia River overbank deposits and overlain by as much as $2 \mathrm{~m}$ of recent Columbia River floodplain deposits (Vogel, 2005). Deposits along Lewis River east of Woodland underlie a sequence of terraces as high as $65 \mathrm{ft}(20 \mathrm{~m})$ above sea level and $30 \mathrm{ft}(10 \mathrm{~m})$ above low-stage Lewis River elevations. Stratified sand and gravel interpreted to represent rapid fluvial aggradation triggered by greatly increased sediment supply following Mount St. Helens eruptions; successional lower terrace treads were cut during post-aggradational downcutting and are locally interbedded with Lewis River alluvium. Pumice and tephra geochemistry and radiocarbon ages show these deposits were mainly produced during and shortly after the Pine Creek (2.9-2.6 ka) and Kalama (C.E. 1479-1720) eruptive periods (Vogel, 2005) and lahar-runout deposits in the Swift Creek drainage derived from pyroclastic and lahar-debris fans formed on south and southeast flanks of Mount St. Helens during dacite dome emplacement. Diamict clast composition of hypersthene-hornblende dacite containing 64-65 percent $\mathrm{SiO}_{2}$ indicates correlation with the Swift Creek eruptive stage of Mount St. Helens (Clynne and others, 2008) at about $16 \mathrm{ka}$. Swift Creek-age deposits are separated from older Cougar-age deposits by a short hiatus

Qsc

Deposits of Cougar eruptive stage (Pleistocene) - Poorly sorted pebbly to bouldery lahar and lahar-runout deposits interbedded with alluvium along the Lewis River (Major and Scott, 1988). Most beds contain clasts of light-colored, coarsely porphyritic quartz-biotite dacite, hornblende-cummingtonite dacite, and hypersthene-hornblende dacite derived from domes, lithic pyroclastic flows, and lahars emplaced during the Cougar eruptive stage of Mount St. Helens between 28 and 16 ka (Clynne and others, 2008)

Qsa Deposits of Ape Canyon eruptive stage and older (Pleistocene)—Alluvium, lahar deposits, minor tephra, and varved silt and clay in terraces along the Lewis River, as much as $40 \mathrm{~m}$ above river level (prereservoir). Clasts are predominantly quartz + biotite \pm cummingtonite-phyric dacitic rock derived from the Mount St. Helens volcanic center during the Ape Canyon eruptive stage of Crandell (1987), between 300 and $35 \mathrm{ka}$, with a long hiatus between 250 and $160 \mathrm{ka}$ (Clynne and others, 2008). Tephra in Ariel quadrangle lithologically equivalent to the $C$ tephra of Ape Canyon age (Mullineaux, 1996) has ${ }^{40} \mathrm{Ar}{ }^{39} \mathrm{Ar}$ age of $269 \pm 13 \mathrm{ka}$, among the oldest known products of the Mount St. Helens center (Evarts, 2004a) 
Mount Hood-derived terrace deposits (Holocene and Pleistocene)-Unconsolidated, stratified sand and gravel composed predominantly of andesitic debris from Mount Hood that was deposited in drainages northwest of the volcano

Youngest terrace deposits (Holocene) - Unconsolidated, stratified sand and gravel and diamictons composed of volcanic debris from Mount Hood transported down Sandy River. Deposits underlie an extensive lowland informally known as the Sandy River delta as well as terraces with treads as high as $60 \mathrm{ft}(18 \mathrm{~m})$ above the Sandy River. As thick as $25 \mathrm{~m}$ in lower Sandy River valley (Pierson and others, 2009) and $9 \mathrm{~m}$ in Sandy River delta where locally interbedded with Columbia River overbank deposits and overlain by as much as $1 \mathrm{~m}$ of recent Columbia River floodplain deposits (Rapp, 2005). Stratified sand and gravel interpreted to represent fluvial aggradation triggered by greatly increased sediment supply following Mount Hood eruptions. Diamictons interpreted as deposits of Mount Hood lahars. Numerous radiocarbon ages (Evarts and others, 2013) and regional stratigraphic relations show that these deposits are younger than 1,600 cal yr B.P. and were produced during and after the Timberline and Old Maid eruptive episodes of Crandell (1980); most are older than 1,200 cal yr B.P. and are related to the Timberline period (Rapp, 2005), but some represent aggradation that culminated as late as the early 1800s during the Old Maid eruptive episode (Pierson and others, 2009). May include local areas of artificial fill

Older post-Missoula deposits (Holocene and Pleistocene) - Sandy cobble to boulder gravel to $20 \mathrm{~m}$ thick underlying terrace surfaces between 160 and $190 \mathrm{ft}$ (50 and $60 \mathrm{~m}$ ) above Sandy River. Poorly exposed, unconsolidated; weakly developed soil profile and $<1 \mathrm{~mm}$ thick weathering rinds on finegrained volcanic clasts suggest relative youth. Not covered by Missoula flood deposits thus postdate 20 - to 15 -ka cataclysmic flooding. Thermoluminescence age of $14.3 \pm 1.2 \mathrm{ka}$ on lithic-rich sand is consistent with post-Missoula flood deposition (table 2). May reflect deposition behind immense Missoula flood bar extending southwestward of Broughton Bluff (Evarts and O'Connor, 2008) that temporarily blocked Sandy River at its confluence with Columbia River. Equivalent, in part, to Estacada Formation of Trimble (1963)

Oldest pre-Missoula deposits (Pleistocene) - Sandy gravel and silty coarse sand with local diamicton that underlies terraces and uplands along the Sandy River. Weathered and unconsolidated to well cemented; forms deposits as thick as $35 \mathrm{~m}$ that underlie dissected benches with surfaces as high as $540 \mathrm{ft}(165 \mathrm{~m})$ elevation, about $400 \mathrm{ft}(120 \mathrm{~m})$ above the river. Some beds contain abundant subrounded clasts, as large as $1 \mathrm{~m}$ across, of Mount Hood-derived hornblende andesite. Other common clast types include light-gray, olivine-phyric, basaltic rocks, andesites eroded from the Rhododendron Formation, dark-gray to black aphyric rocks of the CRBG, and quartzite. Most clasts, especially Mount Hood andesites in upper parts of exposures, are highly weathered and easily cut by shovel or broken by rock hammer, revealing weathering rinds several $\mathrm{mm}$ to $1 \mathrm{~cm}$ thick. Sand matrix commonly leached to light gray. Basal contacts, where exposed, are strath surfaces on hyaloclastic sandstone member of the Troutdale Formation (Tth) at elevations between 300 and $350 \mathrm{ft}$ (90 and $105 \mathrm{~m}$ ). Locally capped by loess (QI) and fine-grained Missoula flood deposits (Qf). Distribution, sedimentary texture, and composition indicate deposition during major, glacially induced(?), aggradational episodes of the ancestral Sandy River, producing a broad fan or braided plain that extended north and west into the eastern Portland Basin. Interbedded diamictons record lahars associated with eruptive activity at Mount Hood. Lack of weathering at contact with overlying fine-grained Missoula flood silt (Qf) indicates that, in part, the unit closely predates the 20-15 ka Missoula floods; optically stimulated luminescence ages from correlative deposits range from $>155 \mathrm{ka}$ to $22.4 \pm 2.5 \mathrm{ka}$ (table 2). Weathering and geomorphic position in places suggest age of parts of unit is much greater than $100 \mathrm{ka}$. Luminescence analysis on sand near the base of the unit in the southern part of the map area indicates some of these deposits are older than $220 \mathrm{ka}$. Corresponds in part to the Estacada Formation as defined and mapped by Trimble (1963), but probably older than the 14- to 12-ka Clackamas River gravel (Wampler, 2004) that composes the type section of the Estacada Formation. Corresponds in part to Gresham Formation of Trimble (1963) floods predominantly originating from glacial Lake Missoula that flowed down the Columbia River and flooded the Willamette Valley and Tualatin Basin (Glenn, 1965; Allison, 1978). Flood deposits underlie much of Portland and the Tualatin and Willamette Valley floors, forming an undulating low-relief surface. Largest flows reached stages of about $120 \mathrm{~m}$ above sea level in the Willamette and Tualatin Valleys, leaving exotic, ice-rafted boulders and cobbles stranded on upland slopes. Maximum thickness of deposits about $35 \mathrm{~m}$ in northern Willamette Valley; thins to $<1 \mathrm{~m}$ at elevations above about $100 \mathrm{~m}$. In the northern Willamette, Tualatin, and Yamhill River valleys, rhythmically layered 
deposits are draped over a relict topography of pre-flood fluvial terraces and valleys. Radiocarbon dating, tephrochronology, and stratigraphic relations from within and outside the map area indicate that most units date from about 18 to $15.7 \mathrm{ka}$ (approximate calendar age from ${ }^{14} \mathrm{C}$ ages in $\mathrm{O}^{\prime}$ Connor and others, 2001, and OSL ages, table 2). Locally, coarse-grained deposits mapped separately:

Coarse-grained Missoula flood deposits - Bouldery, cobbly, sandy gravel. Forms bars deposited by Missoula floods as they spilled into the Portland Basin from the Columbia Gorge, and then into the Tualatin and northern Willamette Basins through the Lake Oswego, Oregon City, and Rock Creek gaps. Crudely stratified, commonly with west and south-dipping foresets. Locally capped by several meters of sandy silt. Drillers' logs indicate that thickness locally exceeds $30 \mathrm{~m}$. (O'Connor and others, 2001)

Qog Older sand and gravel (Pleistocene) - Unconsolidated to semi-consolidated sand and gravel. Deposited in broad braidplains and meandering floodplain environments within the Tualatin and Willamette Basins before the Missoula floods. Forms planar to slightly undulating terrace surfaces 0 to $20 \mathrm{~m}$ above the modern floodplain, for example, along river bluffs between Newberg and Canby. Isotopic dating and tephrochronology indicate these deposits range from $>0.41$ Ma to $\sim 22 \mathrm{ka}$ (O'Connor and others, 2001) Older glacial deposits (Pleistocene)

Qga Amboy Drift - Unconsolidated to compact, massive, poorly sorted till and unconsolidated to poorly consolidated sand, pebble gravel, and cobble gravel outwash. Locally includes lake deposits, loess, and postglacial colluvium. Till mantles areas up to $1,850 \mathrm{ft}(560 \mathrm{~m})$ in elevation in Amboy quadrangle and $1,400 \mathrm{ft}(425 \mathrm{~m})$ in Yacolt quadrangle, is as much as $15 \mathrm{~m}$ thick, and locally rests on surface of glacially smoothed and striated bedrock. Till consists of angular to rounded clasts to boulder size, some grooved or striated, dispersed in matrix of sand, silt, and clay; unoxidized till light brownish to bluish gray. Outwash forms scattered terrace remnants with treads generally below $200 \mathrm{ft}(60 \mathrm{~m})$ elevation on both sides of Lewis River valley and south-sloping fill of basin in which Yacolt is situated, where it is as thick as $42 \mathrm{~m}$ according to well logs. Outwash is moderately weathered, crudely stratified, moderately to well sorted, and commonly weakly cemented by limonite or clay. Composed chiefly of diverse volcanic rocks from the western Cascade Range, but locally contains clasts similar to middle Pleistocene olivine-phyric basalts and basaltic andesites erupted from monogenetic vents in the Lewis drainage (Evarts and Ashley, 1990, 1991). Conspicuous light-colored clasts of coarsely porphyritic quartz-, cummingtonite-, and biotite-bearing dacite like that erupted from the ancestral Mount St. Helens volcanic center (Crandell, 1987) are a minor component in some till, especially north of Lake Merwin. Based on weathering characteristics, Amboy Drift is correlative with Hayden Creek Drift, which Crandell and Miller (1974) interpreted to be the product of the penultimate glaciation in the Washington Cascade Range. Age is uncertain; estimates range from $>300 \mathrm{ka}$ to $\sim 50 \mathrm{ka}$ (Crandell and Miller, 1974; Crandell, 1987; Colman and Pierce, 1986; Dethier, 1988; Grigg and Whitlock, 2002; Evarts and others, 2003). Deposits mapped as Amboy Drift north and west of Yacolt Mountain may locally include a more deeply weathered older drift

Drift of Mason Creek - Deeply weathered, reddish-brown and dark-brown, moderately compact cobbly till and semiconsolidated, gravel, sand, and silt outwash. Composed of deeply weathered, limonitecemented, moderately sorted to well-sorted, well-rounded cobbles and pebbles of volcanic rocks similar to those exposed in the adjacent Cascade Range; locally contains scarce clasts of olivinephyric basalt or basaltic andesite probably eroded from middle Pleistocene volcanic centers in Lewis River drainage (Evarts and Ashley, 1990, 1991). Till occurs on east side of Yacolt Mountain between 1,400 to $1,670 \mathrm{ft}$ ( 425 to $510 \mathrm{~m}$ ) elevation, is present in patchy exposures in Lewis River valley at higher elevations than Amboy Drift, and is as much as $30 \mathrm{~m}$ thick. Hills near Battle Ground Lake, about $640 \mathrm{ft}(195 \mathrm{~m})$ high, may be eroded end-moraine remnants. Outwash forms dissected terrace remnants with surface elevations between about 400 and $700 \mathrm{ft}(120$ and $215 \mathrm{~m})$ in valleys of Cedar Creek and Lewis River (Ariel quadrangle), lower elevations on Lewis River (Woodland quadrangle), and dissected terraces with surfaces at about $400 \mathrm{ft}(120 \mathrm{~m})$ elevation along north flank of Goose Hill and east of Hayes. Distinguished from Amboy Drift by more intense weathering; distinguished from Troutdale Formation by texture and by abundance of Cascade Arc-derived volcanic clasts. Weathering rind thicknesses suggest correlation with Wingate Hill Drift of the Mount Rainier region (Crandell and Miller, 1974; Colman and Pierce, 1986), estimated to be 300-600 ka (Colman and Pierce, 1981; Dethier, 1988). May include deposits of more than one glacial advance gravel. Unconformably overlies Troutdale Formation (Ttf) $\sim 4 \mathrm{~km}$ north of Woodland; about $40 \mathrm{~m}$ thick. Clast composition indicates a Lewis River provenance. Similar to outwash of the drift of Mason Creek (Qgm), but extends to higher elevation (near $600 \mathrm{ft}$ [180 m]) in Deer Island quadrangle, hence interpreted as older than drift of Mason Creek 
Basaltic colluvium (Pleistocene)_-Poorly sorted, weathered, angular to subangular, brown to orange-red, spheroidal basalt cobbles and pebbles in sandy mud matrix of altered basalt. Restriction to low-slope upland surfaces suggests these deposits predate present topography and, perhaps, are early Pleistocene

\section{SEDIMENTARY AND VOLCANIC FILL OF THE PORTLAND, TUALATIN, AND NORTHERN WILLAMETTE BASINS}

Rocks of the Boring Volcanic Field (Pleistocene and Pliocene)—Basalt and basaltic andesite flows, breccia, and tuff. Erupted from dozens of monogenetic centers extending westward from the Cascade Range into the Portland, northern Willamette, and Tualatin Basins. Primary cone and flow morphology preserved locally, although many have been modified by Missoula-flood erosion and sedimentation. Oldest flows have low-potassium tholeiitic compositions; later flows are calc-alkaline. The axis of magmatism has migrated north-northwest across the map area at $9 \mathrm{~mm} / \mathrm{yr}$, in step with clockwise rotation of the Coast Range and late Neogene rifting in the Cascade Volcanic Arc (Fleck and others, 2014; Evarts and others, 2009a). Assigned to six age groups from ${ }^{40} \mathrm{Ar} /{ }^{39} \mathrm{Ar}$ ages of Fleck and others (2014)

QTb6

QTb5

QTb4

QTb3

QTb2

QTb1

Qgcr

QTcr

QTca

QTh

$\mathrm{Tt}$

Tth
90-200 ka (Pleistocene)

200-350 ka (Pleistocene)

0.5-1.3 Ma (Pleistocene)

1.4-1.7 Ma (Pleistocene)

1.9-2.0 Ma (Pleistocene)

2.2-2.7 Ma (Pleistocene and Pliocene)

Gravel of Coast Range provenance (Pleistocene)_Diabase and basalt boulder and cobble gravel forming fans and terraces along major rivers and streams draining the Coast Range; as high as $30 \mathrm{~m}$ in elevation

Older gravel of Columbia River origin (Pleistocene and Pliocene)-Unconsolidated to semiconsolidated, thick-bedded, pebble to boulder conglomerate. Interbedded with basaltic and quartzofeldspathic sandstone and volcanic lithic to micaceous, quartzofeldspathic sand; locally cemented by clay and limonite. Conglomerate varies from well-sorted, clast-supported, imbricated, and cross-bedded deposits composed largely of well-rounded clasts of Columbia River Basalt Group (CRBG) and quartzite to poorly sorted deposits dominated by subangular to subrounded clasts of volcanic rocks eroded from Cascade Range. As much as $90 \mathrm{~m}$ thick. Many fine-grained volcanic clasts in the surficial oxidized zone have weathering rinds of 2-6 mm, and rare clasts have rinds as thick as $1 \mathrm{~cm}$. Less intensely weathered than conglomerate of the Troutdale Formation. Gradationally to unconformably overlies hyaloclastite sandstone member of Troutdale Formation (Tth). Clast weathering, overlying cataclysmic-flood deposits, and luminescence ages from quarries near Scappoose indicate a late Quaternary age of 15 to $80 \mathrm{ka}$ for the upper $8 \mathrm{~m}$ of gravel there. A sandstone bed near Scappoose contains glass shards compositionally similar to Miocene to Pliocene tephras from the Snake River Plain in Idaho but lacks shards resembling tephras from the Quaternary Cascade Range (A.W. Sarna-Wojcicki, USGS, written commun., 2000), which suggests a Pliocene or early Pleistocene depositional age. Most of unit is probably latest Pliocene or early Pleistocene

Older gravel of Cascade Arc origin (Pleistocene and Pliocene)-Unconsolidated sand and sandy to cobbly gravel with local diamicton. Gravel composed of well-rounded to subrounded pebbles and cobbles of volcanic rock, chiefly andesite, derived from Cascade Range to the east. Weathering rinds are $<5$ $\mathrm{mm}$ to $>1 \mathrm{~cm}$ thick. Includes Springwater Formation of Trimble (1963) and deposits inferred to be younger than the Springwater Formation (Evarts and O’Connor, 2008)

Hillsboro formation of Wilson (2000) (Pleistocene to Miocene) — Stratified clay, silt, and fine sand, with local sand and gravel. Abundant augite and little or no hypersthene in the sands indicate Coast Range source. Deposited in low-energy fluvial and lacustrine environment. Overlies CRBG in Tualatin Basin, largely in subsurface; as much as $300 \mathrm{~m}$ thick in well HBD-1 at Hillsboro. Normal magnetic polarity in upper $150 \mathrm{~m}$; base is reverse polarity. Interpreted to be mostly Pleistocene by Wilson (2000), but may extend into late Miocene

Troutdale Formation (Pliocene and Miocene)_-Pebble-cobble conglomerate and pebbly sandstone with lesser claystone, siltstone, and sandstone; poorly to well indurated. Sandstone both lithic vitric and micaceous arkosic

Hyaloclastite sandstone member (Pliocene) — Coarse-grained basaltic sandstone and granule conglomerate. Composed largely of glassy to lithic basaltic clasts; commonly contains dispersed pebbles and cobbles; cobble conglomeratic beds locally abundant. Typical sandy beds are massive, moderately well sorted, crudely stratified, and commonly cross-bedded. Beds consist of angular to subrounded fragments 2 to $6 \mathrm{~mm}$ across of black, generally nonvesicular, basalt. Vitric clasts contain abundant 
pale-brown sideromelane that is variably altered to palagonite, which imparts a distinctive yellowbrown color to the originally dark green rock; clasts cemented by smectitic clay produced during palagonitization. Many beds contain minor amounts of admixed nonvolcanic quartz, muscovite, hornblende, and quartzite grains. Well-rounded to subrounded pebbles and cobbles include varying proportions of olivine-phyric basalt, basaltic rocks of the CRBG, quartzite, and other rock types; some subangular basalt boulders as large as $1 \mathrm{~m}$ across. Thickness may exceed $50 \mathrm{~m}$. Angular nonvesicular vitric clasts probably formed by rapid chilling and quench fragmentation during interaction of basaltic lava with water; cross-stratification, interbedding with conglomerate, and mixing with nonvolcanic debris indicate deposition in fluvial environment, but textural immaturity and monolithologic character of many beds suggest transport was limited. Vitric clasts and associated basalt cobbles have low-potassium-tholeiite composition (Swanson, 1986, 1988; Lite, 1992; A.W. Sarna-Wojcicki, USGS, written commun., 2005), indicating probable derivation from compositionally similar middle Pliocene basalt to the east (Swanson, 1986, 1988; Evarts and others, 2013). Equivalent to informal upper member of Troutdale Formation of Tolan and Beeson (1984); overlies Ttc

Conglomerate member (Pliocene to Miocene)-Massive to crudely stratified, pebbly and cobbly conglomerate. Moderately sorted to well sorted and clast supported, with openwork fabric; contains sparse lenses of friable sandstone or sandstone matrix. Clasts well rounded; clast population dominated by cobbles of basalt from the CRBG but typically includes light-colored granitic and gneissic rocks and distinctive, white to light-gray, iron-oxide-stained quartzite. Clasts of Cascade volcanic rocks are scarce. Sandstone interbeds and matrix of conglomerate range from basaltic grit to micaceous arkose similar to sandstone beds of Sandy River Mudstone (Tsr). These rock types indicate a source east of Cascade Range and deposition by ancestral Columbia River. North of Woodland, unit contains mixed clast population with CRBG and Tertiary volcanic rocks from the Cascade Range. Well logs indicate unit is more than $200 \mathrm{~m}$ thick east of Campen Creek (Washougal quadrangle) and show that weathering may extend to $>30 \mathrm{~m}$ depth (Mundorff, 1964; Swanson and others, 1993). Upper several meters commonly weathered to reddish-brown clayey soil with scattered quartzite pebbles. Basal contact with Sandy River Mudstone is low-relief disconformity. Sedimentary structures consistent with deposition by floods in gravel-dominated braided river system. Equivalent to upper member of Troutdale Formation of Mundorff (1964) and to volcanic-clast and quartzite-clast members of Troutdale Formation of Howard (2002). Late Miocene to early Pliocene age inferred from included CRBG clasts and inferred Pliocene age of overlying basaltic hyaloclastite

Tsm Sandy River Mudstone (Pliocene and Miocene) - Soft arkosic, tuffaceous, and carbonaceous claystone, siltstone, sandstone, and minor pebble conglomerate. Sedimentary structures indicate fluvial and lacustrine depositional environment; fine-grained deposits with thin lignite interbeds probably represent overbank settings on broad floodplain. South of East Fork Lewis River, unit consists largely of friable quartzofeldspathic micaceous sand and silt with minor biotite, tourmaline, magnetite, hornblende; bluish gray where fresh but weathers rapidly to light brown to tan; commonly is limonite cemented. In Saint Helens quadrangle, weathered varicolored claystone, mudstone, siltstone, and minor pebble conglomerate; limonite stained and cemented, locally containing abundant woody fragments; some beds are tuffaceous. Unconformably overlies member of Sentinel Bluffs (Tgsb) of the Grande Ronde Basalt west of the city of St. Helens; 20 to $40 \mathrm{~m}$ thick east of St. Helens; probably much thicker in subsurface to south. In Battle Ground quadrangle, loose to consolidated, medium, fine, and coarse quartzose sand with conspicuous muscovite and clay rip-up clasts as much as $1 \mathrm{~m}$ diameter. Trough cross-bedding indicates north- to northwest-directed paleocurents. In Lacamas Creek, Washougal, Woodland, and Yacolt quadrangles, semiconsolidated, well-bedded sandstone, siltstone, claystone, and minor quartzite-bearing conglomerate, pumice-lapilli tuff, and lignite. Thickness in subsurface highly variable owing to lateral gradations to gravel and to erosion; from about $65 \mathrm{~m}$ in Sandy River area (Swanson and others, 1993) to more than $175 \mathrm{~m}$ thick near Pine Grove, and more than $150 \mathrm{~m}$ thick in northern Washougal quadrangle; may be more than $300 \mathrm{~m}$ thick in Camas quadrangle (Hartford and McFarland, 1989; Swanson and others, 1993). Age poorly known but probably ranges from middle Miocene to middle Pliocene. In Mount Norway area, well logs indicate unit underlies the conglomerate member of the Troutdale Formation (Ttc) along a sharp, probably unconformable, contact, whereas to west, it underlies or is interbedded with lower part of hyaloclastic sandstone member of Troutdale Formation (Ttfh) (Evarts and O'Connor, 2008), which is inferred to be about 3 to 4 million years old. Plant fossils from localities near top of unit along Sandy River assigned an early Pliocene age (Chaney, 1944; Treasher, 1942; Trimble, 1963; Tolan and Beeson, 1984). In quarries southeast of Woodland, flows of the Grande Ronde Basalt overlie or invade this unit, so base must be as old as $16 \mathrm{Ma}$ (late early Miocene) 
Rhododendron Formation (Pliocene and Miocene) - Dominantly volcanic mudflow breccia containing angular blocks as much as 5 or $6 \mathrm{ft}$ across and abundant woody material. East of Estacada in the Clackamas River valley, interbedded andesite flows are common; farther eastward, flow rocks become dominant; about $600 \mathrm{ft}$ thick, but thickens abruptly to the east. Locally deeply weathered with a laterite crust as much as $3 \mathrm{~m}$ thick (Trimble, 1963)

\section{ROCKS OF THE HIGH CASCADE RANGE}

Thb Basalt (Pliocene) - Medium- to dark-gray, coarse-grained basalt. Diktytaxitic, commonly vesicular, with vesicle cylinders and segregation veins; intergranular to subophitic textures; chemically distinguished by low $\mathrm{K}_{2} \mathrm{O}(0.1-0.3$ wt. percent) content. Most outcrops moderately to severely weathered. Normal magnetic polarity (J.T. Hagstrum, USGS, written commun., 2005). K-Ar and ${ }^{40} \mathrm{Ar} /{ }^{39} \mathrm{Ar}$ ages between 3.6 and 3.0 Ma were obtained from correlative flows east of map area (Conrey and others, 1996b; Fleck and others, 2014). Present only in Washougal quadrangle

\section{COLUMBIA RIVER BASALT GROUP AND RELATED STRATA}

Gray to dark-gray-black, variably vesicular, aphyric to sparsely plagioclase-phyric tholeiitic flood basalt and basaltic andesite flows of the Miocene Columbia River Basalt Group (CRBG) underlie much of the map area. The flows were erupted from fissure vents east of the Cascade Range and flowed down an ancestral Columbia River drainage into the Portland area. More than 95 percent of the CRBG was erupted between 16.7 and 15.9 Ma (Kasbohm and Schoene, 2018). Subaerial flows typically exhibit well-developed colonnade and entablature jointing patterns and vesicular flow tops. Pillowed flow margins and flow bases occur where flows filled in existing drainages. Upper few meters of unit are commonly deeply weathered with lateritic paleosols. In major basins, continued subsidence and sedimentary infill have restricted CRBG exposures to basin margins. Thin sedimentary interbeds locally associated with the basalt are not part of the CRBG but are described here for stratigraphic coherence.

\section{Wanapum Basalt (Miocene)}

Priest Rapids Member

Twpr Basalt of Rosalia of Beeson and others (1989a) - Thick flow and associated hyaloclastite of olivineand plagioclase-microphyric basalt. Fills paleocanyon cut into Frenchman Springs Member, Grande Ronde Basalt, and older rocks in Bridal Veil quadrangle (Waters, 1973; Tolan, 1982; Tolan and Beeson, 1984). Unit is $\sim 200 \mathrm{~m}$ thick near southwest margin of paleocanyon at Chanticleer Point; more than 220 $\mathrm{m}$ thick along axis of paleocanyon at Crown Point just east of map area (Tolan, 1982). Hyaloclastite well indurated, poorly sorted, composed of subrounded to well-rounded, sand- to cobble-size clasts of brownish-yellow, partially palagonitized sideromelane (Tolan, 1982). Local foreset bedding and clast imbrication indicate northwest transport direction. Lava flow, with thin colonnade and thick, hackly jointed entablature, sharply overlies and locally invades stratified hyaloclastite that constitutes 25-60 percent of total thickness (Tolan, 1982; Tolan and Beeson, 1984); main channel hyaloclastite locally grades laterally into tributary pillow-lava zones, which are unrelated to basal hyaloclastite (Waters, 1973; Tolan, 1982; Tolan and Beeson, 1984: Wells and others, 2009). Lava flow is plagioclase-microphyric and contains rare plagioclase crystals to $10 \mathrm{~mm}$ long in intergranular to intersertal groundmass of plagioclase, olivine, augite, Fe-Ti oxides, and minor to abundant interstitial glass; vesicles typically filled with yellow clay. Chemistry of flow and hyaloclastite similar (Evarts and others, 2013), resembling the Rosalia chemical type of Swanson and others (1979); distinguished from other Wanapum Basalt flows by higher concentrations of $\mathrm{TiO}_{2}$ ( 3.6 wt. percent), $\mathrm{P}_{2} \mathrm{O}_{5}\left(0.8\right.$ wt. percent), and $\mathrm{FeO}^{*}(>14.5$ wt. percent). Reversed magnetic polarity (Swanson and others, 1979; Tolan, 1982; Tolan and Beeson, 1984). A U/Pb age from zircons in a silicic tuff bed overlying the Rosalia flow on the Columbia Plateau provides a minimum age of the Rosalia flow of $15.895 \pm 0.019 \mathrm{Ma}$ (Kasbohm and Schoene, 2018)

Twfs Frenchman Springs Member Basalt of Sentinel Gap of Mackin (1961) - Blocky to columnar-jointed aphyric basalt. Fresh exposures are dark gray to black; weathered surfaces are brownish red to dark gray. Exposed along Columbia River east of Troutdale

Twfh Basalt of Sand Hollow of Mackin (1961) — Blocky to columnar-jointed, sparsely plagioclase-phyric basalt. Fresh exposures are dark gray to black; weathered surfaces are brownish red to dark gray. Basalt is medium grained, sparsely to abundantly porphyritic, with very sparse, large ( 0.5 to $2 \mathrm{~cm})$ plagioclase phenocrysts. Two normal polarity flows are locally present in the Tualatin Basin and northern Willamette Valley and in the Coast Range (Niem and Niem, 1985; this report). Commonly found as isolated erosional remnants 10 to $40 \mathrm{~m}$ thick along ridge crests. Deeply weathered to spheroidal boulders and weathered fragments in deep red lateritic, pisolitic soils. Flow of basalt of Sand Hollow in northeast Pittsburg and northwest Baker Point quadrangles is abundantly plagioclase-phyric 
Basalt of Ginkgo of Mackin (1961) - Blocky to columnar jointed basalt with large plagioclase phenocrysts. Fresh exposures are dark gray to black; weathered surfaces are brownish red to dark gray. Two flows are locally present in the Tualatin Basin and northern Willamette Valley. In the Red Hills of Dundee, flows occur as isolated erosional remnants 10-40 m thick along ridge crests, commonly deeply weathered and as clasts in deep red lateritic soils. Basalt is medium crystalline, plagioclase microphyric and porphyritic, with large $(0.5-2.5 \mathrm{~cm})$ plagioclase glomerocrysts. Ginkgo flows are distinguished from both younger Frenchman Springs flows and older Grande Ronde Basalt flows by their abundant large plagioclase glomerocrysts, higher $\mathrm{TiO}_{2}$ and $\mathrm{P}_{2} \mathrm{O}_{5}$ contents, and transitional, southeast-seeking, normally polarized paleomagnetic direction

\section{Ellensburg Formation (Miocene)}

Vantage Member-Planar cross-bedded, loose, basalt boulder-pebble gravel and minor coarse-grained brown volcanic lithic arkosic sandstone. Forms 20-m-thick channel in northern Baker Point quadrangle in scattered quarry exposures. Elsewhere, includes fluvial fine- to medium-grained, gray to yellow-brown cross-bedded basaltic arkosic sandstone lenses and lesser yellow-gray tuffaceous overbank mudstone, very thin red claystone, paleosols, and black lignitic layer beneath subaerial basalt of Sand Hollow flow. Locally includes thin, tuffaceous lacustrine siltstone and yellow-orange pisolitic limonite bog iron ore in drilled cores (for example, Iron Crest deposit of Hotz, 1953); present elsewhere but too thin (1-2 m) to map. On the Columbia Plateau, contains a tuff bed dated at $16.066 \pm 0.040 \mathrm{Ma}(\mathrm{U} / \mathrm{Pb}$ on zircons, Kasbohm and Schoene, 2018)

Grande Ronde Basalt (Miocene) - Light- to dark-gray, vesicular to diktytaxitic, aphyric to sparsely plagioclasephyric tholeiitic basaltic andesite. $\mathrm{TiO}_{2}$ contents $<2.7$ percent (table 3; Swanson and others, 1979; Mangan and others, 1986; Beeson and others, 1989a; Reidel and others, 1989; Reidel and Tolan, 2013; http:// or.water.usgs.gov/projs_dir/crbg/data/will_basemap.pdf). About $300 \mathrm{~m}$ thick in Dundee quadrangle and Chehalem Mountains; thins northward and westward. U/Pb ages from interbeds in Grande Ronde Basalt flows on the Columbia Plateau range from 16.2 to $16.5 \mathrm{Ma}$ (Kasbohm and Schoene, 2018). Divided into four informal magnetostratigraphic units based on magnetic polarity, of which N2, R2, and N1 (in order of increasing age, Swanson and others, 1979) occur in map area

TgN2 Tgsb

Tgww

Tgu

Tgo

Tgbc

N2 flows-Normally polarized basalt flows in upper Grande Ronde Basalt

Sentinel Bluffs Member-Blocky to columnar-jointed and locally entablature/colonnade jointed light- to dark-gray basalt with vesicular flow tops. Two or three flows in map area; weathered surfaces are greenish gray to pale gray. Finely to medium crystalline in hand sample, intersertal, in places plagioclase-phyric with sparse, small ( $<0.5 \mathrm{~cm}$ in size) tabular plagioclase phenocrysts. Sentinel Bluffs flows are distinguished from both the younger Frenchman Springs flows and older Grande Ronde units on the combined basis of stratigraphic position, higher $\mathrm{MgO}$ and low $\mathrm{TiO}_{2}$ geochemical composition, lithology, and paleomagnetic directions (see Reidel and others, 1989; Beeson and others, 1989a; Reidel, 2005; Wells and others, 2009; Reidel and Tolan, 2013; Reidel and Tolan, 2013). Unit thickness within the map area is variable, ranging from $10 \mathrm{~m}$ to $25 \mathrm{~m}$

Winter Water Member - One to three flows of entablature/colonnade jointed, light-gray to black, commonly sparsely porphyritic basalt. Flows typically plagioclase-phyric with small $(<0.3 \mathrm{~cm})$ plagioclase glomerocrysts that commonly display a distinctive radial or spoke-shaped habit. Plagioclase glomerocrysts are often unevenly distributed and less abundant near the base of flows. Winter Water flows are distinguished from other Grande Ronde units on the combined basis of stratigraphic position, lithology, geochemical composition, and normal polarity, typically with shallow, northwest paleomagnetic inclination (see Reidel and others, 1989; Beeson and others, 1989a; Wells and others, 1989, 2009; Tolan and Beeson, 1989b; Reidel and Tolan, 2013). Unit thickness within the map area is variable, ranging to as much as $40 \mathrm{~m}$. Locally, some flows mapped separately:

Umtanum flow - One flow of aphyric, entablature/colonnade jointed, light-gray to black basalt. Flow underlies typical plagioclase-phyric Winter Water flows and overlies aphyric Ortley member flows, has composition typical of Winter Water Member but is aphyric, and has the northwest and shallow transitional magnetic direction of some Winter Water flows (Wells and others, 1989; Brodersen, 1995; Reidel and others, 1989)

Ortley member-Three or more basalt flows that typically display large, hackly entablature over small colonnade, with vesicular flow tops. Fresh exposures are dark gray to black; weathered surfaces are greenish gray to dark gray. Ortley flows are commonly glassy to very fine grained and aphyric and have normal polarity, moderate $\mathrm{TiO}_{2}(1.9-2.1$ percent) and $\mathrm{MgO}(\sim 3.4$ percent) contents (Reidel and Tolan, 2013). As much as $60 \mathrm{~m}$ thick

Buttermilk Canyon member-Aphyric, dark-gray to black basalt with hackly entablature over colonnade. Fresh exposures are dark gray to black; weathered surfaces are greenish gray to grayish 
black. Two flows are commonly glassy to finely crystalline, microphyric, with higher $\mathrm{MgO}$ and $\mathrm{TiO}_{2}$ than Ortley member (Reidel and Tolan, 2013); as much as $60 \mathrm{~m}$ thick in Chehalem Mountains

Armstrong Canyon member - One or more basalt flows that typically display hackly entablature over colonnade with vesicular flow tops. Fresh exposures are dark gray to black; weathered surfaces are greenish gray to dark gray. Flows are commonly glassy to very finely crystalline and aphyric. Unit is distinguished from Ortley and Buttermilk Canyon units by its relatively high $\mathrm{MgO}$ content ( 4.0 percent) and lower $\mathrm{TiO}_{2}$ content ( $<1.9$ percent) (Reidel and Tolan, 2013). As much as $60 \mathrm{~m}$ thick in the Chehalem Mountains and Red Hills of Dundee

Tgru $\quad$ N2 and R2 flows-Undifferentiated basalt flows in upper Grande Ronde Basalt. Mapped occurrences are older than Winter Water Member and, in Dixie Mountain and Sauvie Island quadrangles, older than Ortley member. In Baker Point and Bacona quadrangles, aphyric dark-gray R2 Grouse Creek entablature flows or N2 Ortley entablature flows underlie the Winter Water Member

TgR2 R2 flows - Basalt flows of reverse magnetic polarity in middle part of Grande Ronde Basalt; may contain flows of Grouse Creek and Wapshilla Ridge members

Tggc Grouse Creek member-Basalt flows with hackly entablature over colonnade jointing and vesicular flow tops. Fresh exposures are dark gray to black; weathered surfaces are greenish gray to dark gray. Flows are commonly glassy to very finely crystalline and aphyric. Lithologically and chemically very similar to Ortley member flows, but with reverse magnetic polarity (Reidel and Tolan, 2013). Some local pillowed lavas and (or) palagonite breccia and associated autoinvasive dikes in incised paleo-stream valleys in Bacona and Chapman quadrangles. As much as $60 \mathrm{~m}$ thick

Tgwr

Wapshilla Ridge member-Basalt flows typically with hackly entablature over colonnade jointing and vesicular flow tops. Three to five flows in Tualatin Basin and Portland Hills. Fresh exposures are dark gray to black; weathered surfaces are greenish gray to dark gray, commonly glassy to very finely crystalline with distinctive, abundant, acicular microphenocrysts of plagioclase in an aphanitic dark-gray groundmass. Locally pillowed and brecciated, with underlying sedimentary interbeds. In Pittsburg quadrangle, a discontinuous subaerial Wapshilla Ridge flow filled a former incised fluvial valley, was locally eroded, and then overlain by fluvial Gus Creek conglomerate composed largely of acicular microphyric rounded cobbles of Wapshilla Ridge basalt. Distinguished from other Grande Ronde flows by its microphyric appearance, high $\mathrm{TiO}_{2}$ (2.3 to 2.5 percent, higher than other Grande Ronde Basalt members), low $\mathrm{MgO}$ composition, and reverse paleomagnetic polarity (Reidel and Tolan, 2013). As much as $100 \mathrm{~m}$ thick. Zircon samples from tuffs at the base and top of the Wapshilla Ridge Member on the Columbia Plateau are dated at 16.288 $\pm 0.039 / 0.046$ Ma and 16.210 $\pm 0.043 / 0.047$ Ma, respectively (Kasbohm and Schoene, 2018)

Downey Gulch member-Thick basalt flows that typically display hackly entablature over colonnade jointing and vesicular flow tops. Fresh exposures are dark gray to black; weathered surfaces are greenish gray to dark gray, commonly glassy to very finely crystalline or microphyric texture with distinctive, abundant, acicular microphenocrysts of plagioclase in dark-gray groundmass. Underlies the Wapshilla Ridge member of similar appearance, but has somewhat lower $\mathrm{TiO}_{2}$ composition and normal paleomagnetic polarity (Reidel and Tolan, 2013). Unit is at least $20 \mathrm{~m}$ thick along northwest margin of Tualatin Basin, where it may have filled paleovalleys. Exposed on Wildcat Mountain in Buxton quadrangle, where three normal polarity flows underlie a reverse polarity Wapshilla Ridge flow (Dinterman and Duvall, 2009)

Tgc Clastic rocks associated with Grande Ronde Basalt (Miocene) - Basaltic hyaloclastite, sandstone, and conglomerate with chemical affinity to Grande Ronde Basalt in northern part of map area. Includes sedimentary interbeds between Sentinel Bluffs and Winter Water Members (Bacona quadrangle); beds below the Sentinel Bluffs Member (Baker Point quadrangle); arkosic sandstone and mudstone beneath Winter Water Member and above undifferentiated upper Grande Ronde flows (Tgru) (Baker Point quadrangle). Beds associated with Wapshilla Ridge flows in Columbia County are mapped as the Mist formation

Mist formation - Fluvial basalt conglomerate, micaceous sandstone, coal, and lacustrine tuff with freshwater diatoms underlying and locally interbedded with R2 Grande Ronde Basalt. Divided into three members: Gus Creek conglomerate that is interbedded with and overlies the Wapshilla Ridge basalt; finer grained Windy Ridge beds that underlie the Gus Creek and the Wapshilla Ridge, Grouse Creek, and Ortley members; and Ivy Creek siltstone/basalt conglomerate that underlies Windy Ridge member. Formation consists of sediment that fills Miocene paleovalleys that are incised into and overlie a slight angular unconformity on Paleogene marine units in the northwest map quadrant. Van Atta and Kelty (1985) redefined the Scappoose Formation to include these middle Miocene nonmarine strata and molluscan fossil-bearing early Miocene to Oligocene marine strata. We follow Warren and others (1945) 
and restrict the Scappoose to the late Oligocene-earliest Miocene fossiliferous shallow marine strata and assign the middle Miocene nonmarine strata to the Mist formation. Unit is 20-80 m thick

Gus Creek conglomerate-Poorly lithified medium- to dark-brown fluvial pebble, cobble, and boulder basalt conglomerate. Contains a few beds of coarse- to fine-grained micaceous lithic arkosic sandstone and tuffaceous siltstone lenses. Subrounded to rounded conglomerate clasts mostly weathered and fresh, dark gray, microphyric Wapshilla Ridge member of the Grande Ronde Basalt; some angular light-gray tuffaceous siltstone rip-ups. Forms lenses and discontinuous beds (relict channels) beneath basalt flows of Grouse Creek and Ortley members of the Grande Ronde Basalt. Largely overlies basalt flows of Wapshilla Ridge member; where Wapshilla Ridge is absent, directly overlies Windy Ridge member. Locally overlies Scappoose Formation. Unit is 3-30 m thick

Tmwr Windy Ridge member - Laminated, friable, very fine grained, yellow, micaceous arkosic sandstone and trough-cross-bedded to massive, brown, coarse-grained volcanolithic sandstone. Minor interbeds of lignitic coal, sandstone with carbonized plant rootlets, and lacustrine freshwater diatom-bearing tuffaceous siltstone (Eriksson, 2002). Locally includes $10-20 \mathrm{~m}$ of very thinly bedded to very finely laminated, light-gray tuffaceous, micaceous, and carbonaceous siltstone and dark-gray mudstone with leaf fragments. Also includes varicolored (maroon, green, light and medium gray, purple, and red) overbank mudstone with carbonized wood chunks and in situ tree stumps in a black lignitic paleosol. Includes a Cascade-derived, thin, plagioclase-phyric andesite debris-flow deposit in the Chapman quadrangle. Unit is $10-40 \mathrm{~m}$ thick

Tmic Ivy Creek conglomerate - Poorly lithified conglomerate in large-scale planar-cross-bedded channels. Contains abundant subangular tabular pebbles and cobbles of soft, buff-colored tuffaceous siltstone from Pittsburg Bluff and (or) Keasey Formations and lesser deeply weathered, soft, very light gray and medium-gray Grande Ronde Basalt and petrified wood. Elsewhere, dominantly loose, well-rounded, hard cobbles and boulders of fresh aphyric and microphyric Grande Ronde Basalt set in deep red clay and saprolite. Overlies Scappoose, Pittsburg Bluff, and Keasey Formations. A local mudstone debrisflow deposit at the base contains carbonized logs, fossil plants in growth position, recycled late Eocene foraminifers, marine diatoms, and Oligocene pollen (Berkman, 1990). Unit is 5-10 m thick

\section{INTRUSIVE ROCKS}

Tiw Invasive Wanapum Basalt (Miocene) - Irregular dikes and sills of plagioclase-phyric basalt; chemically similar to the Frenchman Springs Member, inferred to be flows that invaded underlying marine sediments (Beeson and others, 1979; Niem and Niem, 1985; Wells and others, 2009). Forms deeply weathered red soils with large spheroidal boulders; locally, large (as much as $1 \mathrm{~cm}$ ) plagioclase phenocrysts are discernible. In deep canyons and quarries around Long Mountain in the Bacona quadrangle; as colonnade- and entablature-weathered plagioclase-phyric basalt below middle Miocene sedimentary strata and subaerial Sand Hollow flow

Tig Invasive Grande Ronde Basalt (Miocene) - Columnar-jointed medium- to dark-gray aphyric to sparsely plagioclase-phyric basalt sills and dikes; inferred to be flows that invaded nonmarine strata of middle Miocene Mist formation (Windy Ridge member) and marine strata of the early Miocene to Oligocene Scappoose Formation. A few bodies have peperitic and baked concordant and discordant contacts and pseudo-pillows cutting across bedding of host sedimentary rocks. Mainly sparsely plagioclase-phyric Winter Water Member and minor aphyric Grouse Creek and Ortley members in the Bacona quadrangle. Invasive Grande Ronde flows are abundant in the Astoria Basin to the west (Niem and Niem, 1985; Wells and others, 2009). Invasive Grande Ronde sills typically form resistant ridges surrounded by older sedimentary units in adjacent lowlands. At a quarry in the western Bacona quadrangle, a subaerial Grouse Creek flow overlying a lignitic paleosol with carbonized tree stumps is traceable over $80 \mathrm{~m}$ to pillow lava and peperitic invasive pods in Windy Ridge micaceous arkosic sandstone. Geochemistry, radiometric ages, and paleomagnetic signature are correlative to adjacent plateau-derived subaerial to subaqueous Columbia River Basalt lavas (Wells and others, 2009)

Tiy Younger intrusions of the Western Cascade Range (Miocene and Oligocene) - Diorite, quartz diorite, and gabbro. Includes diorite of Chelatchie Prairie, diorite of Dunegan Mountain, diorite of Buncombe Hollow, and quartz diorite of Yacolt Mountain

Tio Older intrusions of the Western Cascade Range (Oligocene and Eocene) - Intrusive andesite, basaltic andesite, and basalt, with local quartz diorite and diorite. Includes dikes; irregular, commonly composite, intrusions; and a sill-like body of basalt. Intrusive dacite cuts caldera-fill deposits near Davis Peak

Tis Intrusive rocks of the Coast Range (Eocene) - Basalt, diabase, and gabbro dikes and sills; rare silicic dikes. Diabase is aphyric to plagioclase-phyric, amygdaloidal, with smectite clays and zeolite vesicle fillings; locally pillow form with radial columnar joints, but more commonly tabular bodies with well-developed 
columnar joints and a layered appearance from flow foliation. Weathers to a reddish-orange clay-rich soil containing spheroidally weathered diabase boulders; dominantly of low-K MORB composition. Intrudes lowermost Yamhill Formation containing 45.6 Ma tuff but not upper Yamhill; is cut by $\sim 42 \mathrm{Ma}$ Tillamook feeder dikes. Mostly correlative with the basalt of Hembre Ridge of Wells and others (1995) and basalt of Waverly Heights of Beeson and others (1991). Diabase is of regional extent and, in the map area, mostly postdates deformation of Siletz River Volcanics related to accretion of Siletzia (Wells and others, 2014). Unit may include lesser aphyric and porphyritic basalt dikes and sills, porphyritic basalt, diabase, and silicic dikes largely related to Tillamook Volcanics and sparse, (invasive?) basaltic sills in the Keasey Formation that are chemically distinct from invasive flows of the CRBG

\section{VOLCANIC AND SEDIMENTARY ROCKS OF THE COAST RANGE}

Ts

Tscr

Tsrs

Tsrt

Tsoc

Tsd

Scappoose Formation (Miocene and Oligocene)—Fine- to medium-grained, micaceous arkosic sandstone. Friable, light-gray to yellow, parallel laminated to massive, locally trough cross bedded. Contains shallow-marine fossil mollusks and pumice lapilli; a few 1- to 2-m-thick tuff beds; thin coal beds near top and base of formation. A distinctive cliff-forming dark-brown volcanic debris-flow deposit and fluvial channels of cross-bedded polymict-volcanic conglomerate occur near base of unit along with diatomaceous siltstone beds. A thick sequence of deep-marine, laminated to bioturbated, very thinly bedded, dark-gray claystone and light-gray laminated siltstone forms middle part of formation. East of Gaston and Yamhill and west of the Chehalem Mountains, thin beds of laminated carbonaceous and tuffaceous medium- to fine-grained micaceous, orange- to buff-colored, pumiceous, quartz-rich feldspathic sandstone and mudstone; minor thin volcanic conglomerate and thick laminated to structureless, bioturbated marine tuffaceous mudstone. Molds and casts of a diverse assemblage of shallow marine mollusks have been correlated to the Blakeley Stage (early Miocene to late Oligocene) (Warren and others, 1945; Warren and Norbisrath, 1946). Unit as much as $500 \mathrm{~m}$ thick

Clatskanie River member (Miocene and Oligocene) - Very fine grained to medium-grained, micaceous, carbonaceous, tuffaceous arkosic sandstone. Unit is friable, well laminated to massive, bioturbated, medium gray (fresh) to yellow orange (weathered), and contains molluscan fossils. A few thin intervals of hummocky bedded sandstone; some minor trough-cross-bedded coarse-grained micaceous lithic arkosic sandstone, with very light gray to buff-colored tuff beds and a lignite near top of member. Upper 10-30 $\mathrm{m}$ is generally bioturbated, massive, mollusk-bearing arkosic sandstone; 35-200 m thick. Molluscan fossils assigned by Warren and Norbisrath (1946) to Juanian/ Blakeley stage (earliest Miocene to late Oligocene)

Ribbon Ridge member (Oligocene) - Medium-grained to very fine grained micaceous, quartzofeldspathic sandstone and mudstone. Thin bedded, cross laminated, plane laminated, burrowed, locally carbonaceous, tuffaceous, locally with abundant leaf fossils; rare thin volcanic conglomerate beds near base. Marine, about $200 \mathrm{~m}$ thick. Contains foraminifera dominantly referable to the Zemorrian stage of Kleinpell (1938)

Tuffaceous mudstone - Massive to laminated, white-weathering, gray mudstone; tuffaceous, burrowed, with conchoidal fractures. Marine. Poorly exposed, typically in landslide debris or excavations

Oak Ranch Creek member (Oligocene) - Thick sequence of tuffaceous to micaceous sandy siltstone and dark-gray, bioturbated claystone. Largely deep marine, laminated to very thinly bedded, very light gray (weathered). Locally, scattered, thin, very light gray tuffaceous siltstone beds and a few thick beds of massive, bioturbated, shallow-marine, fossil-mollusk-bearing, fine-grained, tuffaceous arkosic sandstone beds. Siltstone and claystone are locally intensively bioturbated (mainly deep-marine hook-shaped Phycosiphon trace fossils as burrows filled with dark fecal pellets); some bioturbated mollusk-bearing arkosic sandstone beds; some yellow pumice lapilli and abundant carbonized wood along bedding planes. Molluscan fossils are assigned to the Blakeley stage (late Oligocene) equivalent to the late Zemorrian foraminiferal stage. As much as $200 \mathrm{~m}$ thick

Divide member (Oligocene) - Micaceous, arkosic, shallow-marine, mollusk-bearing sandstone. Typically thick bedded, massive to hummocky cross-bedded and laminated, fine to very fine grained, yellow brown (weathered) to medium gray (fresh). Contains 1- to 3-m-thick light-gray tuff; some laminated carbonaceous siltstone and coal beds in trough-cross-bedded, coarse-grained to very coarse grained micaceous lithic arkosic sandstone near top of unit. Locally, top of unit contains very coarse grained lithic arkosic sandstone with lenses of large-scale planar-cross-bedded polymict quartz-volcanic conglomerate containing rounded pebbles of quartz, chert, granite, metamorphic rocks, petrified wood, and Western Cascade-derived porphyritic basalt, andesite, and dark-gray glassy dacite. A 2- to 6-m-thick, well indurated, matrix-supported volcanolithic debris-flow deposit forms a distinctive dark-brown cliff-forming marker unit near the base of the unit. Unit is 50-100 m thick; includes lower Zemorrian 
strata previously mapped as upper Pittsburg Bluff Formation of Moore (1963) and strata of the Blakeley molluscan stage previously mapped as lower Scappoose Formation of Warren and others (1945)

Tpb Pittsburg Bluff Formation (Oligocene and Eocene)_-Massive, bluff-forming, fossiliferous sandy siltstone. Bioturbated, yellow gray, shallow marine; capped by a pyroclastic debris-flow deposit and thin-bedded tuffs. Basal member is thick, pebbly, micaceous arkosic sandstone with scattered lignitic coal beds. Undivided Pittsburg Bluff Formation mapped only in Deer Island and Trenholm quadrangles, where it is about $200 \mathrm{~m}$ thick

Tps Scaponia tuff (Oligocene) - Lapilli tuff, ash tuff, and fine-grained arkosic sandstone. Distinctive debrisflow deposit with abundant yellow pumice lapilli, some angular to subrounded, dark- to mediumgray plagioclase and pyroxene-phyric vesicular basalt and andesite cobbles set in a light-gray ash matrix that contains fresh-water diatoms throughout the matrix and in rounded diatomaceous mud rip-ups. These pyroclastic products and freshwater diatoms were probably derived from an explosive eruption from a Western Cascade Range vent, possibly in a crater lake, which produced a lahar that flowed into the fore-arc basin (McKnight and others, 1995). Lapilli tuff overlain by bioturbated fine-grained arkosic sandstone, other beds of white tuff, and thin-bedded biotite-bearing $29.83 \pm 0.03$ Ma tuff $\left({ }^{40} \mathrm{Ar} /{ }^{39} \mathrm{Ar}\right.$; P. Renne, in McKnight and others, 1995)

East Fork member (Oligocene and Eocene) - Very thick bedded, structureless, bioturbated, finegrained tuffaceous silty sandstone and sandy siltstone; some thin beds of burrowed and laminated white tuff. Forms cliffs, bluffs, and steep, narrow ridges. Ledge-forming calcareous concretionary horizons contain abundant mollusk shells (Niem and Van Atta, 1973; Niem and others, 1994). Distinctive resistant greenish-gray pelletal glauconitic sandstone (3-4 m thick) mapped near base of unit. Unit is similar in appearance to underlying Keasey Formation. Sandstone contains mollusks and tuffaceous clay-filled burrows indicative of shallow marine (middle to inner shelf) depositional environment (Moore, 1976). Unit is as much as $200 \mathrm{~m}$ thick. Mollusks are referred to the Juanian to Galvinian Stages of Addicott (1976) and Moore (1976); benthic foraminifers are referred to the late Refugian Stage of Kleinpell (1938)

Tpp Pebble Creek member (Eocene)_Fine- to coarse-grained, yellow-orange, friable, micaceous arkosic sandstone. Trough- to planar-cross-bedded channels are filled with quartz pebbles, volcanic arkosic sandstone, angular rip-ups, and channel-wall slump blocks of laminated mudstone. Includes thin lignite beds, and thin ripple-laminated to bioturbated beds of dark-gray micaceous siltstone and mudstone as much as $1 \mathrm{~m}$ thick. Mudstone drapes on large foreset cross-beds and flaser bedding and lignitic coal indicates deltaic to estuarine depositional environments. Pebble Creek member fed deep marine canyon-head deposit of Sager Creek formation west of the Pittsburg quadrangle. Unit is 1-80 m thick. Contains foraminifera referable to lower Refugian Stage of Kleinpell (1938)

Tsc Sager Creek formation (Eocene) — Rhythmically bedded, well-laminated, micaceous mudstone interbedded with micaceous, carbonaceous, feldspathic sandstone. Forms thick, deep-marine, foraminifer-bearing turbidite sequence. Sandstone beds display graded Bouma A, B, and C divisions with sharp basal and gradational upper contacts. B beds laminated to micro-cross-laminated. Sandstone locally intercalated with thin beds of mudstone in multiple, cross-cutting, nested channels 30-40 m wide and as much as 20 $\mathrm{m}$ deep. Some laminated sandstone beds form resistant, traceable, 0.5-1 m thick, calcareous concretionary ledges. Mudstone beds contain abundant, deep-marine, hook-shaped Phycosiphon burrows. Bathyal foraminifers are referable to the Refugian Stage (late Eocene to early Oligocene). Maximum thickness of unit is 1,160 m. Channelized unit lies below and beside Pebble Creek member of Pittsburg Bluff Formation and is deeply incised into underlying Keasey Formation (Niem and others, 1992, 1994). Unit may be a canyon-head deposit fed by Pebble Creek sandstone delta to the east (Meyer and Niem, 2002)

Tk Keasey Formation (Eocene) - Massive tuffaceous mudstone. Light gray to buff colored, very thick bedded, bioturbated, derived in large part from a Cascade Volcanic Arc source. Contains some calcareous concretions and ledges, minor glauconitic sandstone, fine-grained micaceous arkosic sandstone and red-brown (weathered) siltstone at base. Cuesta-forming thin-bedded tuffaceous sandy siltstone and tuffs at top of formation. Deep marine; foraminifers referable to latest Narizian and lower Refugian foraminiferal stages of Kleinpell (1938) (McDougall, 1975); fossil mollusks indicate late Eocene to early Oligocene (Hickman, 1976)

Tks Sandstone - Fine- to medium-grained, gray to light-tan, arkosic, micaceous sandstone. Locally crosslaminated, locally indurated, ridge formed near base of Keasey Formation west of Chehalem Creek; as much as $200 \mathrm{~m}$ thick

Tku Upper member-Tuffaceous sandy siltstone. Buff colored to very light gray, indurated, massive to well bedded, with lesser silty very fine grained sandstone, and white tuffs. Contains locally abundant shallow-marine molluscan fossils that indicate continental-shelf water depths. Unit $\sim 100 \mathrm{~m}$ thick 
Tkm Middle member - Largely light gray to buff colored, very thick bedded, commonly structureless, bioturbated, tuffaceous, foraminifer-bearing siltstone and silty claystone. Locally includes thin $(<1$ $\mathrm{m})$, graded, dark-brown, ledge-forming, pebbly, coarse-grained basaltic sandstone beds and lightgray calcareous concretionary horizons. Some mollusks and coldwater-seep carbonate mounds, chimneys, and calcareous masses (Campbell in Niem and others, 1994) occur in this middle to outer-shelf and upper-slope unit. Scattered, thin, buff-colored to white, water-laid tuff beds and calcareous concretionary horizons define stratification in otherwise structureless, bioturbated outcrops, particularly middle of unit. A detrital $\mathrm{U} / \mathrm{Pb}$ zircon age of $36.10 \pm 0.43 \mathrm{Ma}$ was obtained from this unit (L. Staisch and C. Holm-Denoma, USGS, written commun., 2019). As much as 1,000 m thick

Tksm

Tkst

$\mathrm{Tkb}$

Tc

Tcum

Tccw

Stimson Mill member (Eocene) - Fine-grained laminated and cross-laminated basaltic lithic sandstone. Dark green gray, indurated where fresh, massive appearing, with beds of disarticulated pelecypod fossil hash. Weathered outcrop is brown, with distinctive spheroidal weathering; blocks fall apart upon exposure to the elements. Sandstone overlies thin-bedded mudstone with channels of boulder and cobble, matrix-supported diamict containing subrounded basalt and dacite clasts in silica-cemented matrix, interpreted to be submarine debris-flow deposits. As much as $1.2 \mathrm{~km}$ thick. Outcrop is fault bounded, so exact stratigraphic relation is uncertain. Sediment source appears to be volcanics similar to Tillamook Volcanics of Coast Range, but a thick silicic tuff interbed described below, possibly from the Cascade Volcanic Arc, is similar in age to the Keasey Formation tuffaceous mudstone. Foraminifera assigned to Refugian Stage of Kleinpell (1938)

Tuff bed-Silty tuffaceous mudstone, indurated, laminated, weathers white, composed mostly of very fine, glassy, silicic tuff fragments, contains bivalve fossils. Reworked tuff deposited in marine environment. U/Pb detrital zircon age is $36.69 \pm 0.16 \mathrm{Ma}$ (L. Staisch and C. Holm-Denoma, USGS, written commun., 2019). About $10 \mathrm{~m}$ thick

Basal member-Gray-green, indurated, calcite-cemented, pellet-bearing glauconitic sandstone. Contains scattered coldwater-seep carbonate mounds and chimneys with methanogenic pelecypods (Campbell in Niem and others, 1994). Locally includes massive to thin-bedded, dark-gray to weathered red-brown, concretionary, fossiliferous, tuffaceous sandy siltstone. A few coarse-grained, dark-brown, pebbly conglomerate beds contain plagioclase- and pyroxene-phyric basalt clasts, coarse-grained basaltic sandstone, and minor light-gray fine-grained silty lithic micaceous arkosic sandstone. Locally overlies a slight angular unconformity on normal-faulted Goble Volcanics, Cowlitz Formation, and Hamlet formation. Unit 20-80 m thick

Tc Cowlitz Formation (Eocene) - Micaceous arkosic sandstone and overlying mudstone deposited in shallow marine to deltaic environments. Includes coeval Spencer Formation as mapped in Gales Creek, Gaston, and Carlton quadrangles along east side of Coast Range (for example, Schlicker and Deacon, 1967)

Upper mudstone member-Medium-gray, well-laminated, moderately micaceous, deep-marine mudstone and a few thick beds of massive, dark-gray, micaceous sandy siltstone. Foraminifer- and mudpecten-bearing, dark-gray mudstone contains very thin to thin $(<1 \mathrm{~cm})$ beds of light-gray, laminated to starved-ripple-laminated, light-gray turbidite siltstone. Some 10- to 30-m-thick intervals of interbedded, graded, very fine grained, light-gray, micaceous, arkosic turbidite sandstone and mudstone. Uppermost $50 \mathrm{~m}$ of deep-marine unit may contain thick beds of indurated calcite-cemented greenish-gray glauconitic sandstone. Unit is locally absent due to late Eocene episode of normal faulting followed by submarine erosion before deposition of overlying basal tuffaceous Keasey Formation (Niem and others, 1990, 1992). In such cases, Keasey strata directly overlie the sandstone member of the Cowlitz Formation. Thickness generally $<50 \mathrm{~m}$ in outcrop but as much as $200 \mathrm{~m}$ in subsurface in Mist gas field exploration wells (northern Birkenfeld quadrangle). Foraminifera are referred to upper Narizian stage of Mallory (1959) (middle to late Eocene) by McKeel (1983)

Sandstone member-Friable, very thick bedded, structureless to well-laminated, micaceous arkosic sandstone; locally interbedded with subordinate thin beds of laminated, micaceous, bioturbated siltstone, light-gray tuff, and ripple-laminated sandstone and lignitic coal. Sandstone is yellowish gray, fine to medium grained. Locally, sandstone is abundantly carbonaceous and contains laminae with abundant coarse flakes of biotite and muscovite. Largely deltaic. Some sandstone beds are troughcross-bedded, inner shelf or delta front, storm-wave-generated, hummocky bedded or very well laminated deposits. In Exxon GPE Fed. Com. \#1 well (Bacona quadrangle), sandstone is interbedded with well-cemented marginal marine to nonmarine volcaniclastic sandstone and coal and with basalt flows and sills of Goble Volcanics. Member informally known as the gas-producing, Clark and Wilson sandstone reservoir of Mist gas field. Unit is 100-200 m thick in Mist gas field and southern Clear Creek quadrangle; to west, unit thins rapidly and pinches out several kilometers west of map area 
Th Hamlet formation (Eocene) - Thin-bedded, laminated, dark-gray mudstone with fine- to coarse-grained, graded, arkosic and basaltic sandstone, and conglomerate interbeds. Locally glauconitic and fossiliferous; thin tuff beds and calcareous concretions are common. Locally contains arkosic sandstone dikes and exhibits soft-sediment deformation. Base interfingers with fossiliferous brown basalt conglomerate and coarse-grained basaltic sandstone of the Roy Creek member. Unit is bleached and hydrothermally altered adjacent to Miocene and Eocene(?) invasive basalt. Unit includes deep-marine Nestucca Formation mudstone mapped in the Tillamook highlands (Wells and others, 1995). Foraminifera referred to upper Narizian stage of Kleinpell (1938) by W.W. Rau (Washington Geological Survey, written commun., 1982). Coccoliths referable to calcareous nannoplankton zones CP14a and CP14b of Bukry (1973, 1975) and Okada and Bukry (1980); David Bukry cited in Niem and Niem (1985)

Thsw Sweet Home Creek member-Very well laminated, medium-dark-gray, micaceous, deep-marine, foram-bearing mudstone. Contains scattered layers of mud pectens and 30- to 50-m-thick sequences of laminated to micro-cross-laminated, light-gray, very fine grained, arkosic, thin-bedded sandstone turbidites with Bouma B and C divisions. A few scattered, graded, very thin, green glauconitic sandstone beds and brown, graded, pebbly basaltic turbidite sandstone beds. Foraminifera are assigned to Upper Narizian Stage of Mallory (1959). Coccoliths from base to top of section referrable to CP14a and CP14b (David Bukry, USGS, written commun, 2012). Thickness 200-400 m, increases westward

Sunset Highway member-Fine- to medium-grained, micaceous, carbonaceous, arkosic sandstone. Yellow orange in color, moderately indurated. Thick-bedded, well-sorted, middle to upper shoreface sandstone is laminated to hummocky cross-stratified. Member fines upward to thin bedded, very fine grained sandstone interbedded with minor thin-bedded, ripple-laminated to bioturbated siltstone. Arkosic sandstone contains both carbonized fossil plant fragments and shallow-marine mollusk shells. Some thick, indurated, basalt-pebble, debris-flow deposits and thick beds of gritty to pebbly coarse-grained brown basaltic sandstone within the shallow marine arkosic sandstone; gradational basal contact with underlying Roy Creek member. Unit is 20-40 m thick. Foraminifera are assigned to the Upper Narizian Stage

Roy Creek member-Basaltic conglomerate, basaltic sandstone, and siltstone, with dark-greenish-gray to weathered, dark-brown boulder and pebble conglomerate at base. Locally contains dacite boulders where unit overlies rare silicic flows. Overlies an erosional unconformity on subaerial Tillamook Volcanics flows; locally interfingers with upper Tillamook flows. Subrounded conglomerate clasts derived from Eocene paleo-sea cliffs of Tillamook Volcanics islands. Well cemented by sparry calcite, clay minerals, and zeolites. Sandstone in upper part is thin to medium bedded, very coarse grained, and bears shallow marine mollusks, including Ostrea (shallow water oysters) and barnacle plates (Safley, 1989; Mumford, 1988; Niem and Niem, 1985; Wells and others, 1995). Generally <40 m thick

Tillamook Volcanics (Eocene) - Thick sequence of submarine pillow basalt, hyaloclastic basalt breccia, and overlying subaerial basalt flows, with minor fluvial basalt conglomerate and reddish paleosols. Volcanics are interpreted as forming overlapping oceanic-island shield volcanoes generated at a hot spot (Wells and others, 1995, 2014). Comprises much of the Coast Range highlands west of map area (Wells and others, 1995)

Ttva Subaerial flows - Platy to columnar-jointed, dark-gray to brown tholeiitic and alkalic basalt and basaltic andesite. Commonly plagioclase-, augite-, and olivine-phyric. Local reddish, oxidized, vesiculated and brecciated flow tops and bases. Characterized by pilotaxitic flow texture of aligned plagioclase microlites with titaniferous augite and high $\mathrm{TiO}_{2}$ content (2.5-4.0 percent). Minor, thin, multi-colored, tuffaceous mudstone interbeds and reddish-brown paleosols. Basaltic pebble-boulder conglomerate, breccia, debris-flow deposits, and red scoria and bedded hyaloclastite occur locally. Flows form gently north dipping, offlapping shield volcanoes that become younger to north; maximum thickness is $8 \mathrm{~km}$, about $30 \mathrm{~km}$ west of map area. West of map area, hornblende-biotite dacite, rhyodacite, and rhyolite with $\mathrm{SiO}_{2}$ up to 72 percent at top of section (Wells and others, 1995). At Green Mountain, north of U.S. Hwy 26, platy flow-banded glassy high-Fe porphyritic andesite and dacite (66 percent $\mathrm{SiO}_{2}$ ) cap a second basalt shield sequence. Subaerial flows locally interfinger with overlying conglomerate and basaltic sandstone of Roy Creek and thin-bedded siltstone of the Sweet Home Creek member of the Hamlet formation, which contain foraminifera referable to the upper part of the Narizian stage of Mallory (1959) and coccolith flora referable to CP14a and CP14b (David Bukry in Niem and Niem, 1985; Wells and others, 2014). Marine siltstone at the base of the subaerial flows contains foraminifera referable to both lower and upper Narizian stages (W.W. Rau, Washington Geological Survey, written commun., 1983); and coccolith flora referable to CP14a (Wells and others, 2014). Flows are entirely of reverse magnetic polarity west of map area, becoming normally polarized north of map area. Flows west of map area have U-Pb isotopic age of 41.6 $\pm 0.4 \mathrm{Ma}$ (Wells and others, 2014). $\mathrm{A}^{40} \mathrm{Ar}{ }^{\beta 9} \mathrm{Ar}$ age of $40.3 \pm 0.3 \mathrm{Ma}$ was obtained from uppermost part of Tillamook Volcanics at Rocky Point quarry in the Clear Creek quadrangle (Niem, 2009) 
Ttvm Submarine flows and breccias-Tholeiitic to alkalic pillow basalt and pillow breccias. Commonly augite \pm plagioclase \pm olivine-phyric. High titanium ( $>2.5$ percent) compositions; thick bedded to massive, locally includes normally graded palagonitic tuff, crystal lithic tuff, and basalt lapilli tuff commonly cemented by zeolite or calcite; also includes basaltic sandstone, mudstone, and polymict mudflow breccia. Interbedded marine mudstone of the Yamhill Formation contains foraminifera referable to both lower and upper parts of the Narizian stage of Mallory (1959) (W.W. Rau, Washington Geological Survey, written commun., 1987) and coccolith flora referable to CP14a (Wells and others, 2014)

Tbwh Basalt of Waverly Heights (Eocene) - Blocky to columnar-jointed basalt flows. Typically fine to medium grained; very sparsely plagioclase-phyric to abundantly plagioclase-phyric with plagioclase phenocrysts and glomerocrysts usually $<0.5 \mathrm{~cm}$; small olivine (now iddingsite) and augite phenocrysts locally evident. Well-developed vesicular tops and (or) flow-top breccias. Fresh surfaces typically brownish gray to black; weathered surfaces dark gray to brownish black. Vesicles and vugs within the flow tops and some joints commonly filled with secondary calcite, zeolites, and silica. Mudstone interbeds, commonly $<0.3 \mathrm{~m}$ thick, are likely paleosols. Presence of paleosols and absence of pillow lava and hyaloclastite suggest subaerial emplacement. Thickness at least $500 \mathrm{~m}$; base not exposed. $\mathrm{A}^{40} \mathrm{Ar} /{ }^{39} \mathrm{Ar}$ total-fusion

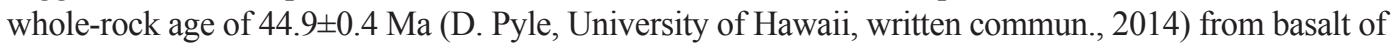
Waverly Heights is partly equivalent to ages in Hembre Ridge unit in the Coast Range west of the map area (Wells and others, 1995, 2014; see also Hammond and others (2014)

Ty Yamhill Formation (Eocene) - Massive to thin-bedded and laminated dark-gray siltstone with minor tuff and sandstone. Locally channelized and interbedded with submarine basalt lapilli breccia. Tuffaceous, thin-bedded mudstone near base of Yamhill Formation contains white silicic tuff beds as much as 30 $\mathrm{cm}$ thick. In Carlton quadrangle, siltstone and mudstone, dark gray, laminated, finely micaceous and carbonaceous, thin to massively bedded, with calcareous and iron stained concretions and carbonaceous plant fragments. Unit contains minor lithic sandstone, submarine basaltic lapilli breccia, and white, cross-bedded and ripple-laminated, silicic tuff beds. Thin, graded, arkosic sandstone beds occur in upper part of unit. Interpreted as slope mudstone with slope channels of turbidite sandstone and basalt lapilli breccia. Lower part of unit is intruded by thick, regional diabase sill complex (Tis) that is in turn cut by Tillamook feeder dikes. Thickness at least $500 \mathrm{~m}$; sill complex obscures much of the stratigraphy. Forms lowlands and low hills covered by thin mantle of Missoula flood silt below 400-ft elevation. Exposure is poor; weathered, yellowish-tan siltstone is exposed in roadside ditches and animal burrows. Coccoliths west of Scoggins Dam are assigned to CP13c. West of map area beneath Tillamook Volcanics, Yamhill coccoliths are assigned to CP14a (Wells and others, 1995). Zircons from tuff at base of unit have U-Pb isotopic ages of $46.5 \pm 0.5 \mathrm{Ma}$ (Wells and others, 2014)

Siletz River Volcanics (Eocene) - Pillow basalt, subaerial basalt flows, basalt breccia, submarine basaltic tuffs, diabase sills, and interbedded lithic sandstone and mudstone

Tsra Subaerial flows - Columnar-jointed subaerial basalt flows with red-oxidized weathered flow tops and interbedded rhyolite ash-flow tuff in Gales Creek area. Includes tuffaceous mudstone, diabase sills, minor submarine pillow basalt flows, and interbedded flow breccias, commonly amygdaloidal, with zeolite and smectite vesicle fillings. In Fairdale quadrangle, columnar-jointed basalt with red-oxidized weathered flow tops; overlain by submarine basalt lapilli tuff and intruded by diabase sills. Thickness is $1.2 \mathrm{~km}$ east of Gales Creek. Zircons from 15 -m-thick rhyolitic ash-flow tuff in quarry near top of section in Gales Creek quadrangle have a U-Pb age of 49.5 $\pm 0.2 \mathrm{Ma}$ (Wells and others, 2014)

Tsrf Silty interbeds - Thin-bedded, laminated tan siltstone. Some interbeds appear to be marine; others may include continental sediments and paleosols between subaerial flows. Commonly weathered and intruded by diabase

Tsrm Submarine flows and breccias - Submarine pillow-basalt flows, filled lava tubes, and interbedded flow breccias. Abundantly augite- and plagioclase-phyric in upper part, commonly amygdaloidal, with zeolite and smectite vesicle fillings and slickensided shear surfaces containing clay, calcite, zeolite, quartz, and pyrite. Base is not exposed in Oregon; base of Siletz oceanic basalt terrane is $22-32 \mathrm{~km}$ beneath the Oregon Coast Range (Trehu and others, 1994). Sedimentary interbeds west of map area contain foraminifera referable to lower Ulatisian or Penutian stages (W.W. Rau, Washington Geological Survey, written commun., 1970) and calcareous nannoplankton referable to CP11 and CP9b. An age of 50.6 \pm 0.8 Ma was determined from pillow basalt in the Nestucca River, and a U-Pb isotopic age of $52 \pm 1$ Ma was determined for a tuff interbed in the Trask River Basin (Duncan, 1982; Wells and others, 2014)

\section{YOUNGER ROCKS OF THE WESTERN CASCADE RANGE}

Tys Volcaniclastic sedimentary rocks (Oligocene) - Volcaniclastic siltstone, sandstone, grit, conglomerate, and breccia. In Amboy and Yacolt quadrangles, thin- to thick-bedded, well-sorted to poorly sorted volcanic 
siltstone, sandstone, grit, conglomerate, and clast-supported breccia inferred to be of epiclastic origin. Locally includes thin lignite beds, diamict of probable lahar origin, and rare pumiceous pyroclastic rocks. Beds dark green and brown where fresh; weather light brown to olive green, greenish gray, tan, or white; locally developed paleosols typically maroon. Texturally and compositionally immature; clasts are similar to interbedded lava flows and tuffs. Plant remains, including reed and leaf impressions, locally abundant. Interpreted as debris eroded from adjacent volcanoes and deposited in low-lying fluvial and lacustrine settings. Moderate to pervasive alteration to clay minerals, zeolites, quartz, and calcite; more intensely weathered than associated lava flows. In Camas and Washougal quadrangles, volcaniclastic rocks interbedded with basaltic andesite flows (Tbem). Primarily massive, light-green to dark-brown, lithic lapilli tuff composed of angular to subrounded volcanic lithic and pumice clasts to $5 \mathrm{~cm}$ across in sandy to silty matrix; pervasively altered to smectite, kaolinite, and zeolites. Abundance, variety, and subrounded character of lithic clasts suggests unit consists largely of debris flow rather than primary pyroclastic flow deposits

Tyv Volcanic rocks (Oligocene)-Locally tuff and tuff breccia

Tyvd Dacite - Sparsely plagioclase-phyric dacite flow and flow breccia with phenocrysts of plagioclase, olivine, and clinopyroxene in Camas quadrangle. Age unknown but overlies basaltic andesite of Elkhorn Mountain (Tbem). In Yacolt quadrangle, flow of medium- to dark-gray, porphyritic to glomerophyric, mafic dacite with phenocrysts of plagioclase, augite, hypersthene, and Fe-Ti oxide. ${ }^{40} \mathrm{Ar} r{ }^{39} \mathrm{Ar}$ age on plagioclase of $26.4 \pm 0.1 \mathrm{Ma}$

Tyva Andesite - Scattered outcrops of platy, porphyritic to seriate andesite; overlies and interbedded with basaltic andesite of Elkhorn Mountain (Tbem)

Tyvba Basaltic andesite - Flows and flow breccia of dark-gray to brown, porphyritic to seriate to aphyric basaltic andesite

Tyvb Basalt-Dark-gray, coarse-grained, seriate, low-potassium tholeiitic basalt with phenocrysts and glomerocrysts of plagioclase, olivine, and augite

Tbem Basaltic andesite of Elkhorn Mountain (Oligocene) - Lava flows and flow breccia composed of dark-gray to brown, porphyritic to seriate to aphyric tholeiitic basaltic andesite and basalt; locally includes minor volcaniclastic rocks. Flows about 5-8 $\mathrm{m}$ thick with platy to blocky to columnar jointing. Flows are tholeiitic, with $\mathrm{FeO}^{*}$ as high as 13 wt. percent and poor in $\mathrm{Sr}(<300 \mathrm{ppm})$ compared to mafic rocks elsewhere in southern Washington Cascade Range (du Bray and others, 2006; Evarts, 2006a,b; Evarts and O'Connor, 2008). As much as $1.3 \mathrm{~km}$ thick. ${ }^{40} \mathrm{Ar} /{ }^{39} \mathrm{Ar}$ ages range from 27.1 \pm 0.1

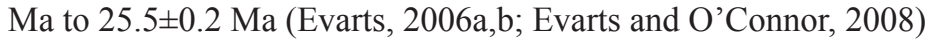

\section{OLDER ROCKS OF THE WESTERN CASCADE RANGE}

Tos Volcaniclastic sedimentary rocks (Oligocene and Eocene)-Volcaniclastic siltstone, sandstone, conglomerate, and breccia. In Ariel and Woodland quadrangles, consists of generally well bedded, well-sorted to poorly sorted siltstone, sandstone, conglomerate, and breccia; locally includes thin beds of pumiceous pyroclastic rocks and lava flows. Interpreted as epiclastic debris eroded from volcanoes and deposited in low-lying areas. Unit typically displays intense low-grade alteration to clay minerals and zeolites. In Ridgefield quadrangle, thin lenses, typically $<5 \mathrm{~m}$ thick, of epiclastic volcaniclastic rocks interbedded with andesitic flows. In Yacolt quadrangle, includes volcaniclastic strata below unconformity at base of basaltic andesite of Elkhorn Mountain (Tbem). Similar to volcaniclastic strata elsewhere but locally

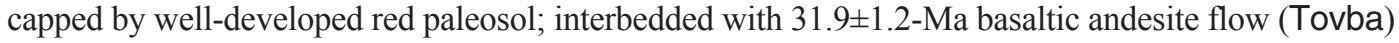

Tuff (Oligocene and Eocene) - Light-green to brown andesitic to rhyolitic tuff, pumice and lithic-lapilli tuff, and tuff breccia. Very poorly sorted, matrix-supported, relatively coarse grained deposits predominate in Woodland and Ariel quadrangles; inferred to be mostly of pyroclastic-flow and lahar origin but includes some airfall tuff and reworked debris. Locally includes subordinate pumice-poor epiclastic sedimentary rocks. Phenocrysts generally constitute $<10$ percent of juvenile material in tuff, and include plagioclase, augite, hypersthene, and Fe-Ti oxide, but no quartz, amphibole, or biotite. ${ }^{40} \mathrm{Ar} /{ }^{39} \mathrm{Ar}$ ages of $33.4 \pm 0.4 \mathrm{Ma}$ and $33.0 \pm 0.1$ (Amboy quadrangle)

Tov Volcanic rocks (Oligocene and Eocene) - Intermediate to mafic flows. In the Battle Ground quadrangle, called the Skamania volcanic series by Trimble (1963); metamorphosed to zeolite facies. In the Ridgefield quadrangle, massive polylithologic volcanic diamict, interbedded lapilli tuff, and andesite flows. Vitric material altered to clay and zeolite

Tovr Rhyolite - Porphyritic rhyolite with phenocrysts of plagioclase and pyroxene. Includes rhyolite of Bald Mountain in the Ariel quadrangle

Tovd Dacite-Flows, flow breccia, and domes of variably porphyritic dacite. Commonly exhibits minor to pervasive low-temperature alteration 
Tova Andesite - Flows and flow breccia of medium- to dark-gray, aphyric to porphyritic pyroxene andesite. Locally includes small flows of basaltic andesite and dacite, thin volcaniclastic interbeds, and andesite dikes. Common minor low-temperature alteration to quartz, smectitic clay, and (or) calcite

Tovba Basaltic andesite - Flows and flow breccia of dark-gray to brown, porphyritic to seriate to aphyric basaltic andesite in Amboy, Ariel, Deer Island, and Woodland quadrangles; locally includes minor andesite and basalt flows and volcaniclastic rocks. In Woodland and Deer Island quadrangles, includes massive, unsorted, monolithologic diamict composed of angular clasts as large as $1 \mathrm{~m}$ of dark-gray to reddish-gray, aphanitic to seriate, sparsely vesicular basaltic andesite in yellowishgray matrix of comminuted basaltic andesite. Texture of deposit is similar to 1980 debris-avalanche deposit at Mount St. Helens. Wilkinson and others (1946) interpreted diamict as a lens within the Troutdale Formation and inferred it was the product of contemporaneous volcanism. Petrographic similarity to some Eocene basaltic andesite flows and $\mathrm{a}^{40} \mathrm{Ar} /{ }^{39} \mathrm{Ar}$ age of $37.3 \pm 0.3 \mathrm{Ma}$ indicate it is Eocene, although an origin as a Neogene landslide deposit cannot be ruled out

Basalt - Basalt and basaltic andesite flows and isolated outcrops of basaltic agglomerate

Ttdp

Tuff of Davis Peak (Eocene) - Caldera-fill and outflow facies of variably welded ash-flow tuff from Davis Peak caldera. Caldera fill is composed chiefly of olive-green to brown, variably compacted, porphyritic, dacitic pumice-lapilli tuff, intercalated with a variety of poorly sorted lithic breccias interpreted as landslide deposits generated by collapse of unstable caldera walls during paroxysmal eruption; includes coherent megaclasts of precaldera rocks tens of meters across. Lithic fragments in lapilli tuff highly variable; angular clasts of mafic to silicic lavas similar to precaldera units are most common. At least $500 \mathrm{~m}$ thick. Tuff and breccias are typically propylitized. Outflow unit of porphyritic, densely welded, dacitic tuff exposed on south side of Cedar Creek is at least $30 \mathrm{~m}$ thick. Plagioclase from fresh, black, densely welded plagioclase- and pyroxene-phyric vitrophyre of the caldera fill on south flank of Davis Peak yielded ${ }^{40} \mathrm{Ar} /{ }^{39} \mathrm{Ar}$ age of $35.2 \pm 0.3 \mathrm{Ma}$ (Ariel quadrangle), and plagioclase from the outflow facies yielded ${ }^{40} \mathrm{Ar} /{ }^{39} \mathrm{Ar}$ age of $35.1 \pm 0.3 \mathrm{Ma}$

Togv Goble Volcanics (Eocene) - Dark-gray to brown, subaerial low- $\mathrm{TiO}_{2}$ basaltic andesite flows and flow breccias along Columbia River. Interbedded with subordinate light-gray, white to green andesitic to rhyolitic tuff, pumiceous lapilli tuff, and matrix-supported pumiceous and lithic pyroclastic flows and lahars (Evarts, 2002). Lava flows 3-6 m thick, blocky columnar to platy jointed with reddish zeolite-filled vesicular flow tops. Some flows separated by reddish-brown paleosols and (or) tuffaceous interbeds. Mafic flows typically contain abundant plagioclase and minor augite, hypersthene, and some olivine phenocrysts set in once glassy groundmass now largely altered to smectite clay, quartz, Fe-Ti oxides and calcite. ${ }^{40} \mathrm{Ar} /{ }^{39} \mathrm{Ar}$ age of plagioclase separated from pumice lapilli is 36.1 \pm 0.3 Ma (R.J. Fleck, 1999, in Evarts, 2002). Wilkinson and others (1946) mapped some rocks on the east bank of the Columbia River as Goble Volcanics. Following Evarts (2002), we map these rocks as thick basaltic andesitic lavas (Tovba), pyroclastic flows, lahars, and andesitic to rhyolitic tuffs (Tot) of the western Cascades. Farther west, forms channelized, close-packed, greenish-black, submarine pillow-lava flows, vesicular basaltic breccias, filled lava tubes with radiating joints.

Also forms invasive sills and dikes of abundantly plagioclase- and pyroxene-phyric alkalic to calcalkaline basaltic andesite; mapped by Niem and Niem (1985) as Cole Mountain basalt member of Cowlitz Formation, now recognized as part of the Goble Volcanics. Chert, chalcedony, quartz, calcite, pyrite, and zeolite blebs fill interstices and vesicles. Widespread in subsurface west of Columbia River; as much as 1,000 m of lava flows, debris flow deposits, and volcaniclastic rocks encountered in the Exxon GPE Fed. Com \#1 and Crown Zellerbach 2 exploration wells in the Bacona quadrangle. ${ }^{40} \mathrm{Ar} /{ }^{39} \mathrm{Ar}$ whole-rock ages of basalt from the wells range from $35.02 \pm 0.26 \mathrm{Ma}$ to $38.9 \pm 0.3 \mathrm{Ma}$ (R. Duncan, Oregon State University, written commun. to A.R. Niem, 2009) 


\section{References Cited}

Achterman, G., Williamson, K., Lundy, J., Klingeman, P.C., and Jarvis, W.T., 2005, Preliminary summary of aggregate mining in Oregon with emphasis in the Willamette River Basin: Oregon State University, Institute for Natural Resources Administrative Report, 55 p.

Addicott, W.O., 1976, Neogene molluscan stages of Oregon and Washington, in Fritsche, A.E., Ter Best, Harry, Jr., and Wornardt, W.W., eds., The Neogene symposium; selected technical papers on paleontology, sedimentology, petrology, tectonics and geologic history of the Pacific Coast of North AmericaTomorrow's oil from today's provinces: Society of Economic Paleontologists and Mineralogists, Pacific Section, Proceedings, no. 51, p. 95-115.

Allen, J.E., 1975, Volcanoes of the Portland area: The Ore Bin, v. 37, p. 145-157.

Allen, J.E., Burns, M., and Burns, S.F., 2009, Cataclysms on the Columbia, the great Missoula floods: Portland State University, Ooligan Press, 204 p.

Allison, I.S., 1978, Late Pleistocene sediments and floods in the Willamette Valley: The Ore Bin, v. 40, p. 177-203.

Armentrout, J.M., and Suek, D.H., 1985, Hydrocarbon exploration in western Oregon and Washington: American Association of Petroleum Geologists Bulletin, v. 69, p. 627-643.

Atwater, B.F., 1987, Evidence for great Holocene earthquakes along the outer coast of Washington State: Science, v. 236, no. 4804, p. 942-944.

Atwater, B.F., Musumi-Rokkaku, S., Satake, K., Tsuji, Y., Ueda, K., and Yamaguchi, D.K., 2015, The orphan tsunami of 1700Japanese clues to a parent earthquake in North America (2nd ed.): Seattle, University of Washington Press and U.S. Geological Survey Professional Paper 1707, 135 p.

Baker, V.R., and Bunker, R.C., 1985, Cataclysmic late Pleistocene flooding from glacial Lake Missoula — a review: Quaternary Science Reviews, v. 4, p. 1-41.

Baker, D., Peterson, C., Hemphill-Haley, E., and Twichell, D., 2010, Latest Pleistocene and Holocene (2-16 ka) sedimentation in the Columbia River Estuary, Oregon, USA: Marine Geology, v. 273, no. 1-4, p. 83-95.

Balsillie, J.H., and Benson, G.T., 1971, Evidence for the Portland Hills Fault: The Ore Bin, v. 33, p.109-118.

Barnard, K.N., 2016, The terroir of pinot noir wine in the Willamette Valley, Oregon - a broad analysis of vineyard soils, grape juice and wine chemistry: Portland State University, Ph.D. dissertation paper 2941, 455 p.

Barnett, E.A., Weaver, C.S., Meagher, K.L., Haugerud, R.A., Wang, Z., Madin, I.P., Wang, Y., Wells, R.E., Blakely, R.J., Ballantyne, D.B., and Darienzo, M., 2009, Earthquake hazards and lifelines in the Interstate 5 urban corridor-Woodburn, Oregon, to Centralia, Washington: U.S. Geological Survey Scientific Investigations Map 3027, scale 1:150,000, at http://pubs.usgs.gov/sim/3027/.

Barry, T.L., Kelley, S.P., Reidel, S.P., Camp, V.E., Self, S., Jarboe, N.A., Duncan, R.A. and Renne, P.R., 2013, Eruption chronology of the Columbia River Basalt Group, in Reidel, S.P., Camp, V.E., Ross, M.E., Wolff, J.A., Martin, B.S., Tolan, T.L., and Wells, R.E., eds., The Columbia River flood basalt province: Geological Society of America Special Paper 497, p. 45-66.
Beck, M.E., 1976, Discordant paleomagnetic pole positions as evidence of regional shear in the western Cordillera of North America: American Journal of Science, v. 276, p. 694-712.

Beeson, M.H., Fecht, K.R., Reidel, S.P., and Tolan, T.L., 1985, Regional correlations within the Frenchman Springs Member of the Columbia River Basalt Group-New insights into the middle Miocene tectonics of northwestern Oregon: Oregon Geology, v. 47, p. 87-96.

Beeson, M.H., and Moran, M.R., 1979, Columbia River Basalt Group stratigraphy in western Oregon: Oregon Geology, v. 41, no. 1, p. 1114.

Beeson, M.H., Perttu, R., and Perttu, J., 1979, The origin of the Miocene basalts of coastal Oregon and Washington-An alternative hypothesis: Oregon Department of Geology and Mineral Industries, Oregon Geology, v. 41, no. 10, p. 159-166.

Beeson, M.H., and Tolan, T.L., 1990, The Columbia River Basalt Group in the Cascade Range; a middle Miocene reference datum for structural analysis: Journal of Geophysical Research, v. 96, p. 19,547-19,559.

Beeson, M.H., Tolan, T.L., and Anderson, J.L., 1989a, The Columbia River Basalt Group in western Oregon; geologic structures and other factors that controlled flow emplacement patterns, in Reidel, S.P., and Hooper, P.R, eds., Volcanism and tectonism in the Columbia River flood basalt province: Geological Society of America Special Paper 239, p. 223-246.

Beeson, M.H., Tolan, T.L. and Madin, I.P., 1989b, Geologic map of the Lake Oswego quadrangle, Clackamas, Multnomah, and Washington Counties, Oregon: Oregon Department of Geology and Mineral Industries, Geological Map Series, GMS 59, scale $1: 24,000$.

Beeson, M.H., Tolan, T.L., and Madin, I.P., 1991, Geologic map of the Portland quadrangle, Multnomah and Washington Counties, Oregon, and Clark County, Washington: Oregon Department of Geology and Mineral Industries Geological Map Series GMS-75, scale 1:24,000.

Benito, G., and O'Connor, J.E., 2003, Number and size of lastglacial Missoula floods in the Columbia River valley between the Pasco Basin, Washington, and Portland, Oregon: Geological Society of America Bulletin, v. 115, p. 624-638.

Berkman, T.A., 1990, Surface-subsurface geology of the middle to upper Eocene sedimentary and volcanic rock units, western Columbia County, northwest Oregon: Corvallis, Oregon State University, M.S. thesis, 413 p.

Blakely, R.J., Wells, R.E., Tolan, T.L., Beeson, M.H., Trehu, A.M., and Liberty, L.M., 2000, New aeromagnetic data reveal large strike-slip (?) faults in the northern Willamette Valley, Oregon: Geological Society of America Bulletin, v. 112, p. 1225-1233.

Blakely, R.J., Wells, R.E., Yelin, T.S., Madin, I.P., and Beeson, M.H., 1995, Tectonic setting of the Portland-Vancouver area, Oregon and Washington - constraints from low-altitude aeromagnetic data: Geological Society of America Bulletin, v. 107, p. 1051-1062.

Bott, J.D.J., and Wong, I.G., 1993, Historical earthquakes in and around Portland, Oregon: Oregon Geology, v. 55, p. 116-122.

Bretz, J.H., 1925, The Spokane flood beyond the Channeled Scablands: Journal of Geology, v. 33, p. 97-115, 236-259.

Bretz, J.H., 1959, Washington's Channeled Scabland: Washington Division of Mines and Geology Bulletin 45, 55 p. 
Bretz, J.H., 1969, The Lake Missoula floods and the Channeled Scabland: Journal of Geology, v. 77, p. 505-543.

Brodersen, B.T., 1995, The geology of Parrett Mountain, Oregon, and its influences on the local groundwater systems: Portland, Oregon, Portland State University, M.S. thesis, 572 p.

Bromery, R.W., and Snavely, P.D., Jr., 1964, Geological interpretation of reconnaissance gravity and aeromagnetic surveys in northwestern Oregon: U.S. Geological Survey Bulletin 1181-N, p. 1-53.

Brownfield, M.E., 2011, Total petroleum systems and geologic assessment of undiscovered hydrocarbon resources of the western Oregon and Washington Province, Chapter 2 of 4, in Geologic assessment of undiscovered hydrocarbon resources of the western Oregon and Washington Province: U.S. Geological Survey Digital Data Series DDS-69-X.

Bukry, D., 1973, Coccolith stratigraphy, eastern equatorial Pacific, Leg 16, Deep Sea Drilling Project: Initial Reports of the Deep Sea Drilling Project, v. 16, p. 653-711.

Bukry, D., 1975, Silicoflagellate and coccolith stratigraphy, Deep Sea Drilling Project, Leg 29: Initial Reports of the Deep Sea Drilling Project, v. 29, p. 845-872.

Burns, W. J., and Coe, D.E, 2012, Missoula floods-Inundation extent and primary flood features in the Portland metropolitan area, Clark, Cowlitz, and Skamania Counties., Washington, and Clackamas, Columbia, Marion, Multnomah, Washington, and Yamhill Counties, Oregon: Oregon Department of Geology and Mineral Industries map IMS-36, scale 1:8,200.

Burns, W.J., Mickelson, K.A., Duplantis, S., and Madin, I.P., 2012, Landslide inventory maps of the Dixie Mountain quadrangle, Washington, Multnomah, and Columbia Counties, Oregon: Oregon Department of Geology and Mineral Industries map IMS-44, 4 plates, scale 1:8,000.

Burns, S.F., 2012, The importance of soil and geology in tasting terroir with a case history from the Willamette Valley, Oregon, in Dougherty, P.H., ed., The geography of wine; regions, terroir, and techniques: Springer, p. 95-108.

Burt, W., Conlon, T., Tolan, T.L., Wells, R.E., and Melady, J., 2009, Hydrogeology of the Columbia River Basalt Group in the northern Willamette Valley, Oregon, in O'Connor, J., Dorsey, R., and Madin, I., eds., Volcanoes to vineyards - Geologic field trips through the dynamic landscape of the Pacific Northwest: Geological Society of America Field Guide 15, p. 697-736.

Cannon, C.M, Ramirez, M.F., Heatwole, D.W., Burke, J.L., Simenstad, C.A., O’Connor, J.E., and Marcoe, K., 2012, Columbia River Estuary Ecosystem Classification geospatial data: Lower Columbia Estuary Partnership, accessed July 15, 2018, at http://www.estuarypartnership.org/columbia-riverestuary-ecosystem-classification.

Chaney, R.W., 1944, Pliocene floras of California and Oregon: Carnegie Institution of Washington, Contributions to Paleontology, no. 553, 407 p.

Clynne, M., Calvert, A.T., Wolfe, E.W., Evarts, R.C., Fleck, R.J., and Lanphere, M.A., 2008, The Pleistocene eruptive history of Mount St. Helens, Washington, from 300,000 to 12,800 years before present, in Sherrod, D.R., Scott, W.E., and Stauffer, P.H., eds., A volcano rekindled-The renewed eruption of Mount St. Helens, 2004-2006: U.S. Geological Survey Professional Paper 1750 , p. 593-627.
Cohen, K.M., and Gibbard, P., 2011, Global chronostratigraphical correlation table for the last 2.7 million years: Cambridge, England, Subcommission on Quaternary Stratigraphy (International Commission on Stratigraphy), accessed July 15, 2018, at http:// quaternary.stratigraphy.org/charts/.

Conlon, T.D., Wozniak, K.C., Woodcock, D., Herrera, N.B., Fisher, B.J., Morgan, D.S., Lee, K.K., and Hinkle, S.R., 2005, Ground-water hydrology of the Willamette Basin, Oregon: U.S. Geological Survey Scientific Investigations Report 2005-5168, 83 p., at http://pubs.usgs.gov/sir/2005/5168/.

Conrey, R.M., Sherrod, D.R., Uto, K., and Uchiumi, S., 1996b, Potassium-argon ages from Mount Hood area of Cascade Range, northern Oregon: Isochron West, no. 63, p. 10-20.

Conrey, R.M., Uto, K., Uchiumi, S., Beeson, M.H., Madin, I.P., Tolan, T.L., and Swanson, D.A., 1996a, Potassium-argon ages of Boring Lava, northwest Oregon and southwest Washington: Isochron West, no. 63, p. 3-9.

Crandell, D.R., 1980, Recent eruptive history of Mount Hood, Oregon, and potential hazards from future eruptions: U.S. Geological Survey Bulletin 1492, 81 p.

Crandell, D.R., 1987, Deposits of pre-1980 pyroclastic flows and lahars from Mount St. Helens, Washington: U.S. Geological Survey Professional Paper 1444, 91 p.

Crandell, D.R., and Miller, R.D., 1974, Quaternary stratigraphy and extent of glaciation in the Mount Rainier region, Washington: U.S. Geological Survey Professional Paper 847, 59 p.

Darton, N.H., 1909, Structural materials in parts of Oregon and Washington: U.S. Geological Survey Bulletin 387, 36 p.

Dean, W.E., Kennett, J.P., Behl, R.J., Nicholson, C., and Sorlien, C.C., 2015, Abrupt termination of Marine Isotope Stage 16 (Termination VII) at $631.5 \mathrm{ka}$ in Santa Barbara Basin, California: Paleoceanography, v. 30, p. 1373-1390, at https://doi. org/10.1002/2014PA002756.

Dethier, D.P., 1988, The soil chronosequence along the Cowlitz River, Washington: U.S. Geological Survey Bulletin 1590-F, p. F1-F47.

Diller, J.S., 1915, Guidebook of western U.S., Part D: U.S. Geological Survey Bulletin 614, p.1-142.

Dinterman, P.A., and Duval, A.R., 2009, Preliminary geologic map of the Buxton 7.5' quadrangle, Washington County, Oregon: U.S. Geological Survey Open-File Report 2009-1186, scale 1:24,000, database accessed July 15, 2018, at http://pubs. usgs.gov/of/2009/1186/.

du Bray, E.A., John, D.A., Sherrod, D.R., Evarts, R.C., Conrey, R.M., and Lexa, J., 2006, Geochemical database for volcanic rocks of the western Cascades, Washington, Oregon, and California: U.S. Geological Survey Data Series 155, at http://pubs. usgs.gov/ds/2006/155.

Duncan, R.A., 1982, A captured island chain in the Coast Range of Oregon and Washington: Journal of Geophysical Research, v. 87, p. 10827-10837.

Eriksson, A., 2002, Stratigraphy, structure, and natural gas potential of Tertiary sedimentary and volcanic units, Clatskanie 7.5-minute quadrangle, northwest Oregon: Corvallis, Oregon State University, unpublished M.S. thesis.

Evarts, R.C., 2002, Geologic map of the Deer Island quadrangle, Columbia County, Oregon, and Cowlitz County, Washington: U.S. Geological Survey Miscellaneous Field Studies Map 
MF-2392, scale 1:24,000, pamphlet 45 p., and database, at https://pubs.usgs.gov/mf/2002/2392/.

Evarts, R.C., 2004a, Geologic map of the Ariel quadrangle, U.S. Geological Survey Scientific Investigations Map 2826, scale 1:24,000, 35 p., at https://pubs.usgs.gov/sim/2004/2826/.

Evarts, R.C., 2004b, Geologic map of the Woodland quadrangle, Cowlitz and Clark Counties, Washington: U.S. Geological Survey Scientific Investigations Map 2827, scale 1:24,000, pamphlet 38 p., at https://pubs.usgs.gov/sim/2004/2827/.

Evarts, R.C., 2004c, Geologic map of the Saint Helens quadrangle, Columbia County, Oregon, and Cowlitz and Clark Counties, Washington: U.S. Geological Survey Scientific Investigations Map 2834, scale 1:24,000, pamphlet 23 p., at https://pubs. usgs.gov/sim/2004/2834/.

Evarts, R.C., 2004d, Geologic map of the Ridgefield quadrangle, Clark and Cowlitz Counties, Washington: U.S. Geological Survey Scientific Investigations Map 2844, scale 1:24,000, pamphlet 22 p., at https://pubs.usgs.gov/sim/2004/2844/.

Evarts, R.C., 2005, Geologic map of the Amboy quadrangle, Clark and Cowlitz Counties, Washington: U.S. Geological Survey Scientific Investigations Map 2885, scale 1:24,000, pamphlet 25 p., at https://pubs.usgs.gov/sim/2005/2885/.

Evarts, R.C., 2006a, Geologic map of the Yacolt quadrangle, Clark County, Washington: U.S. Geological Survey Scientific Investigations Map 2901, scale 1:24,000, pamphlet 32 p., at https:// pubs.usgs.gov/sim/2006/2901/.

Evarts, R.C., 2006b, Geologic map of the Lacamas Creek quadrangle, Clark County, Washington: U.S. Geological Survey Scientific Investigations Map 2924, scale 1:24,000, pamphlet 21 p., at https://pubs.usgs.gov/sim/2006/2924/.

Evarts, R.C., and Ashley, R.P., 1990, Preliminary geologic map of the Cougar quadrangle, Cowlitz and Clark Counties, Washington: U.S. Geological Survey Open-File Report 90-631, scale 1:24,000.

Evarts, R.C. and Ashley, R.P., 1991, Preliminary geologic map of the Lakeview Peak quadrangle, Cowlitz County, Washington: U.S. Geological Survey Open-File Report 91-289, scale $1: 24.000$

Evarts, R.C., Ashley, R.P., and Smith, J.G., 1987, Geology of the Mount St. Helens area-record of discontinuous volcanic and plutonic activity in the Cascade Arc of southern Washington: Journal of Geophysical Research, v. 92, p. 10,155-10,169.

Evarts, R.C., Clynne, M.A., Fleck, R.J., Lanphere, M.A., Calvert, A.T., and Sarna-Wojcicki, A.W., 2003, The antiquity of Mount St. Helens and the age of the Hayden Creek Drift [abs.]: Geological Society of America Annual Meeting Abstracts with Programs, v. 35, no. 6, p. 80.

Evarts, R.C., Conrey, R.M., Fleck, R.J., and Hagstrum, J.T., 2009a, The Boring Volcanic Field of the Portland-Vancouver area, Oregon and Washington-Tectonically anomalous forearc volcanism in an urban setting, in O'Connor, J.E., Dorsey, R.J., and Madin, I.P., eds., Volcanoes to vineyards - Geologic field trips through the dynamic landscape of the Pacific Northwest: Geological Society of America Field Guide 15, p. 253-270, at https://doi.org/10.1130/2009.fld015(13).

Evarts, R.C., and O'Connor, J.E., 2008, Geologic map of the Camas quadrangle, Clark County, Washington, and Multnomah County, Oregon: U.S. Geological Survey Scientific Investiga- tions Map 3017, scale 1:24,000, pamphlet 31 p., at https://pubs. usgs.gov/sim/3017/.

Evarts, R.C., O’Connor, J.E., and Cannon, C.M., 2016, Geologic map of the Sauvie Island quadrangle, Multnomah and Columbia Counties, Oregon, and Clark County, Washington: U.S. Geological Survey Scientific Investigations Map 3349, scale 1:24,000, pamphlet 34 p., at https://dx.doi.org/10.3133/sim3349.

Evarts, R.C., O’Connor, J.E., and Tolan, T.L., 2013, Geologic map of the Washougal quadrangle, Clark County, Washington, and Multnomah County, Oregon: U.S. Geological Survey Scientific Investigations Map 3257, scale 1:24,000, pamphlet 46 p., at https://pubs.usgs.gov/sim/3017/.

Evarts, R.C., O’Connor, J.E., Wells, R.E., and Madin, I.P., 2009b, The Portland Basin - a (big) river runs through it: GSA Today, v. 19, issue 9, p. 4-10, accessed July 15, 2018, at https:/www.geosociety.org/gsatoday/archive/19/9/article/i1052-5173-19-9-4.htm.

Evarts, R.C., and Swanson, D.A., 1994, Geologic transect across the Tertiary Cascade Range, southern Washington, in Swanson, D.A., and Haugerud, R.A., eds., Geologic field trips in the Pacific Northwest, 1994 Geological Society of America Meeting: Seattle, University of Washington, p. 2H1-2H31.

Fleck, R.J., Hagstrum, J.T., Calvert, A.T., Evarts, R.C., and Conrey, R.M., 2014, ${ }^{40} \mathrm{Ar} /{ }^{39} \mathrm{Ar}$ geochronology, paleomagnetism, and evolution of the Boring volcanic field, Oregon and Washington, USA: Geosphere, v. 10, no. 6, p. 1283-1314, at https://doi.org/10.1130/GES00985.1.

Freund, R., 1974, Kinematics of transform and transcurrent faults: Tectonophysics, v. 21, no. 1, p. 93-134.

Gannett, M.W., and Caldwell, R.R., 1998, Geologic framework of the Willamette Lowland aquifer system, Oregon and Washington: U.S. Geological Survey Professional Paper 1424-A, 32 p.

Glenn, J.L., 1965, Later Quaternary sedimentation and geological history of the north Willamette Valley, Oregon: Corvallis, Oregon, Oregon State University, Ph.D. dissertation, 231 p.

Gradstein, F.M., Ogg, J.G., Schmitz, M., and Ogg, G., eds., 2012, The geologic time scale 2012: Elsevier, 2 v., 1146 p.

Grigg, L.D., and Whitlock, C., 2002, Patterns and causes of millennial-scale climate change in the Pacific Northwest during Marine Isotope stages 2 and 3: Quaternary Science Reviews, v. 21, p. 2067-2083.

Hammond, P.E., Scott, M., McClaughry, J.D., Niem, A., Ferns, M.L., and Nelson, B., 2014, A possible dislocated track of the Yellowstone mantle plume in the Pacific Northwest [abs.]: Geological Society of America Abstracts with Programs, v. 46, no. 5 , p. 93.

Hart, D.H., and Newcomb, R.C., 1965, Geology and ground water of the Tualatin Valley, Oregon: U.S. Geological Survey WaterSupply Paper 1793, 78 p.

Hartford, S.V., and McFarland, W.D., 1989, Lithology, thickness, and extent of hydrogeologic units underlying the east Portland area, Oregon: U.S. Geological Survey Water-Resources Investigations Report 88-4110, $23 \mathrm{p}$.

Haugerud, R.A., 2004, Cascadia-Physiography: U.S. Geological Survey Geologic Investigations Map I-2689, scale $1: 2,000,000$.

Heusser, C.J., and Heusser, L.E., 1980, Sequence of pumiceous tephra layers and the late Quaternary environmental record near Mount St. Helens: Science, v. 210, no. 4473, p.1007-1009. 
Hickman, C.S., 1976, Bathyal gastropods of the family Turridae in the early Oligocene Keasey Formation in Oregon, with a review of some deep-water genera in the Paleogene of the eastern Pacific: Bulletins of American Paleontology, v. 70, no. 292, 119 p.

Hodge, E.T., 1938, Geology of the lower Columbia River: Geological Society of America Bulletin, v. 49, p. 836-929.

Hoffmeister, R.J., 2000, Slope failures in Oregon-GIS inventory for three 1996/97 storm events: Oregon Department of Geology and Mineral Industries Special Paper 34, 20 p., 1 compact disc.

Hoffstetter, W.F., 1984, Geology of the Portland well field: Oregon Geology, v. 46, p. 63-67.

Hooper, P.R., 2000, Chemical discrimination of Columbia River basalt flows: Geochemistry, Geophysics, Geosystems, v. 1, 17 p., at https://doi.org/10.1029/2000GC000040.

Hotz, P.E., 1953, Limonite deposits near Scappoose, Columbia County, Oregon: U.S. Geological Survey Bulletin 982-C, 93 p.

Howard, K.A., 2002, Geologic map of the Battle Ground 7.5-minute quadrangle, Clark County, Washington: U.S. Geological Survey Miscellaneous Field Studies Map MF-2395, scale 1:24,000, pamphlet 18 p., at https://pubs.usgs.gov/ $\mathrm{mf} / 2002 / 2395 /$.

Ignizio, D.A., O’Donnell, M.S., and Talbert, C.B., 2014, Metadata Wizard-An easy-to-use tool for creating FGDC-CSDGM metadata for geospatial datasets in ESRI ArcDesktop: U.S. Geological Survey Open-File Report, 2014-1132, 14 p., at https://doi.org/10.3133/ofr20141132.

Johnson, D.M., Hooper, P.R., and Conrey, R.M., 1999, XRF analysis of rocks and minerals for major and trace elements on a single low dilution Li-tetraborate fused bead: Advances in X-ray Analysis, v. 41, p. 843-867.

Kasbohm, Jennifer, and Schoene, Blair, 2018, Rapid eruption of the Columbia River flood basalt and correlation with the mid-Miocene climate optimum: Science Advances, v. 4, no. 9, eaat8223.

Kelsey, H.M., Engebretson, D.C., Mitchell, C.E., and Ticknor, R.L, 1994, Topographic form of the Coast Ranges of the Cascadia margin in relation to coastal uplift rates and plate subduction: Journal of Geophysical Research, v. 99, p. 12245-12255.

Kleinpell, R.M., 1938, Miocene stratigraphy of California: Tulsa, Oklahoma, American Association of Petroleum Geologists Special Volume SP9, 450 p.

Lawes, J.L., III, 1997, Geochemistry, stratigraphy and provenance of the Portland Hills Silt in the Tualatin Mountains, Portland, Oregon: Portland, Oregon, Portland State University, M.S. thesis, $243 \mathrm{p}$.

Lentz, R.L., 1981, The petrology and stratigraphy of the Portland Hills Silt-A Pacific Northwest loess: Oregon Geology, v. 43, no. 1, p. 3-10.

Libbey, F.W., Lowry, W.D., and Mason, R.S., 1945, Ferruginous bauxite deposits in northwestern Oregon: Oregon Department of Geology and Mineral Industries, Bulletin 29, 97 p.

Liberty, L.M., Hemphill-Haley, M.A., and Madin, I.P., 2003, The Portland Hills Fault - Uncovering a hidden fault in Portland, Oregon, using high-resolution geophyscial methods: Tectonophysics, v. 368, no. 1-4, p. 89-103.

Lipman, P.W., and Mullineaux, D.R., 1981, The 1980 eruptions of Mount St. Helens, Washington: U.S. Geological Survey Professional Paper 1250, 844 p.
Lite, K.E., Jr., 1992, Stratigraphy and structure of the southeast part of the Portland Basin, Oregon: Portland, Oregon, Portland State University, M.S. thesis, 82 p.

Lowry, W.D., and Baldwin, E.M., 1952, Late Cenozoic geology of the lower Columbia River valley, Oregon and Washington: Geological Society of America Bulletin, v. 63, p. 1-24.

Ma, L., Madin, I.P., Olson, K.V., Watzig, R.J., Wells, R.E., and Priest, G.R., comps., 2009, Oregon geologic data compilation [OGDC], release 5 (statewide): Oregon Department of Geology and Mineral Industries Digital Data Series OGDC-5, CD-ROM.

Ma, Lina, Madin, I.P., Duplantis, S., and Williams, K.J., 2012, Lidar-based surficial geologic map and database of the greater Portland, Oregon, area, Clackamas, Columbia, Marion, Multnomah, Washington, and Yamhill Counties, Oregon, and Clark County, Washington: Oregon Department of Geology and Mineral Industries Open-File Report O-2012-02, 30 p., geodatabase, scale, 1:63,360.

Mabey, M., Black, G., Madin, I., Meier, D., Youd, T.L., Jones, C., and Rice, B., 1997, Relative earthquake hazard map of Portland metro region, Clackamas, Multnomah, and Washington Counties, Oregon: Oregon Department of Geology and Mineral Industries Map IMS-1, scale 1:62,500 and 1:216,000.

Mackin, J.H., 1961, A stratigraphic section in the Yakima Basalt and the Ellensburg Formation in south-central Washington: Washington Division of Mines and Geology Report of Investigations, v. 19, 45 p.

Madin, I.P., 1990, Earthquake-hazard geology maps of the Portland metropolitan area, Oregon - text and map explanation: Oregon Department of Geology and Mineral Industries OpenFile Report 0-90-2, 21 p.

Madin, I.P., 1994, Geologic map of the Damascus quadrangle, Clackamas and Multnomah Counties, Oregon: Oregon Department of Geology and Mineral Industries Geologic Map Series GMS-60, scale 1:24,000.

Madin, I.P., 2004, Geologic mapping and database for Portland area fault studies: Oregon Department of Geology and Mineral Industries Open-File Report O-04-02.

Madin, I., 2009, Geologic map of the Oregon City 7.5' quadrangle, Clackamas County, Oregon: Oregon Department of Geology and Mineral Industries Geologic Map Series GMS-119, scale $1: 24,000$.

Madin, I.P., Priest, G.R., Mabey, M.A., Malone, S., Yelin, T.S., and Meier, D., 1993, March 25, 1993, Scotts Mills earthquake-western Oregon's wakeup call: Oregon Geology, v. 55, no. 3 , p. 51-57.

Magill, J.R., Wells, R.E., Simpson, R.W., and Cox, A.V., 1982, Post-12 m.y. rotation of southwest Washington: Journal of Geophysical Research: Solid Earth, v. 87, B5, p. 3761-3776.

Mallory, V.S., 1959, Lower Tertiary biostratigraphy of the California Coast Ranges: American Association of Petroleum Geologists, 416 p. , accessed July 15, 2018, at https://pubs. geoscienceworld.org/books/book/1482/lower-tertiary-biostratigraphy-of-the-california.

Mangan, M.T., Wright, T.L., Swanson, D.A., and Byerly, G.R., 1986, Regional correlation of Grande Ronde Basalt flows, Columbia River Basalt Group, Washington, Oregon, and Idaho: Geological Society of America Bulletin, v. 97, p. 1300-1318. Martin, B.S., Tolan, T.L., and Reidel, S.P., 2013, Revisions to the 
stratigraphy and distribution of the Frenchman Springs Member, Wanapum Basalt, in Reidel, S.P., Camp, V.E., Ross, M.E., Wolff, J.A., Martin, B.S., Tolan, T.L., and Wells, R.E., eds., The Columbia River flood basalt province: Geological Society of America Special Paper 497, p.155-179.

McCaffrey, R., King, R.W., Payne, S.J., and Lancaster, M., 2013, Active tectonics of northwestern U.S. inferred from GPSderived surface velocities: Journal of Geophysical Research, v. 118, at https://doi.org/10.1029/2012JB009473.

McCaffrey, R., Qamar, A.I., King, R.W., Wells, R.E., Khazaradze, G., Williams, C.A., Stevens, C.W., Vollick, J.J., and Zwick, P.C., 2007, Fault locking, block rotation and crustal deformation in the Pacific Northwest: Geophysical Journal International, v. 169, p. 1315-1340, at https://doi.org/10.1111/j.1365246X.2007.03371.x.

McDougall, K., 1975, The microfauna of the type section of the Keasey Formation of northwestern Oregon, in Weaver, D.W., Hornaday, G.R., and Tipton, A., eds., Future energy horizons of the Pacific Coast: American Association of Petroleum Geologists, Society of Economic Paleontologists and Mineralogists, and Society of Economic Geologists, Pacific Section Annual Meeting, Long Beach, California, p. 343-359.

McFarland, W.D., and Morgan, D.S., 1996, A description of the ground-water flow system in the Portland Basin, Oregon and Washington: U.S. Geological Survey Water-Supply Paper 2470-A, 58 p., 7 pl.

McKeel, D.R. 1983, Subsurface biostratigraphy of the east Nehalem Basin, Columbia County, Oregon: Oregon Department of Geology and Mineral Industries Oil and Gas Investigation 9, 34 p.

McKeel, D.R., 1985, Biostratigraphy of exploratory wells, southern Willamette Basin, Oregon: Oregon Department of Geology and Mineral Industries Oil and Gas Investigation OGI-13, 17 p.

McKnight, B.K., Niem, A.R., Kociolek, P., and Renne, P., 1995, Origin of a freshwater-diatom-rich pyroclastic-debris-flow deposit in a shallow-marine Tertiary forearc basin, northwest Oregon: Journal of Sedimentary Research, v. 65, p. 505-512.

McPhee, D.K., Langenheim, V.E., Wells, R.E., and Blakely, R.J., 2014, Tectonic evolution of the Tualatin Basin, northwest Oregon, as revealed by inversion of gravity data: Geosphere, v. 10 , no. 2, p. 264-275.

Meyer, H.J., 2001, 3-D helps see through the mist: American Association of Petroleum Geologists Explorer, v. 22, no. 4, p. 37-39.

Meyer, H.J., and Niem, A.R., 2002, An example of late Eocene/ early Oligocene sea floor topography imaged by 3-D seismic data, Mist Gas Field, and in outcrop, North Coast Range, Oregon: Geological Society of America Abstracts with Programs, v. 35, no. 6, p. A-33.

Minervini, J.J., O’Connor, J.E., and Wells, R.E., 2003, Maps showing inundation depths, ice-rafted erratics, and sedimentary facies of late Pleistocene Missoula floods in the Willamette Valley, Oregon: U.S. Geological Survey Open-File Report 03-408, scale 1:250,000.

Moore, E.J., 1963, Miocene marine mollusks from the Astoria Formation in Oregon: U.S. Geological Survey Professional Paper 419, 109 p.

Moore, E.J., 1976, Oligocene marine mollusks from the Pittsburg Bluff Formation in Oregon, U.S. Geological Survey Professional Paper 922, 66 p.
Mullineaux, D.R., 1996, Pre-1980 tephra-fall deposits erupted from Mount St. Helens, Washington: U.S. Geological Survey Professional Paper 1563, 99 p., at http://pubs.er.usgs.gov/publication/pp1563, accessed August 8, 2018.

Mumford, 1988, Geology of the Nehalem River-Elsie area, southcentral Clatsop and northern Tillamook Counties, northwestern Oregon: Corvallis, Oregon State University, M.S. thesis, 433 p.

Mundorff, M.J., 1964, Geology and ground-water conditions of Clark County, Washington, with a description of a major alluvial aquifer along the Columbia River: U.S. Geological Survey Water-Supply Paper 1600, 268 p., scale 1:48,000.

Newton, V.C., Jr., 1969, Subsurface geology of the lower Columbia and Willamette Basins, Oregon: Oregon Department of Geology and Mineral Industries Oil and Gas Investigation 2, 121 p.

Newton, V.C., Jr., and Van Atta, R.O., 1976, Prospects for natural gas production and underground storage of pipeline gas in the upper Nehalem River Basin, Columbia-Clatsop counties, Oregon: Oregon Department of Geology and Mineral Industries Oil and Gas Investigation 5, 56 p., scale 1:62,500.

Niem, A., 2009, Oil and Gas Report to Venneco Energy, unpublished, $30 \mathrm{p}$.

Niem, A.R., MacLeod, N.S., Snavely, P.D., Jr., Huggins, D., Fortier, J.D., Meyer, H.J., Seeling, A.F., and Niem, W.A., 1992, Onshore-offshore geologic cross section, northern Oregon Coast Range to continental slope: Oregon Department of Geology and Mineral Industries Special Paper 26, 1 plate, $10 \mathrm{p}$.

Niem, A.R., McKnight, B.K., Meyer, H.J., and Campbell, K.A., 1994, Sedimentary, volcanic, and tectonic framework of forearc basins and the Mist Gas Field, northwest Oregon, in Swanson, D.A., and Haugerud, R.A., eds., Geologic field trips in the Pacific Northwest: Geological Society of America, Annual Meeting, Seattle, v. 1, section F, p. 1-42.

Niem, A.R., and Niem, W.A., 1985, Geologic map of the Astoria Basin, Clatsop and northernmost Tillamook Counties, northwest Oregon: Oregon Department of Geology and Mineral Industries Oil and Gas Investigations, OG-14.

Niem, A.R., Snavely, P.D., Jr., and Niem, W.A., 1990, Onshoreoffshore geologic cross section from the Mist Gas Field, northern Oregon Coast Range, to the northwest Oregon continental shelf and slope: Oregon Department of Geology and Mineral Industries Continental Margin Transect OGI-17, 1 plate, 46 p.

Niem, A.R., and Van Atta, R.O., 1973, Cenozoic stratigraphy of northwestern Oregon and adjacent southwestern Washington, in Beaulieu, J.D., ed., Geologic field trips in northern Oregon and southern Washington: Oregon Department of Geology and Mineral Industries Bulletin 77, p. 75-132.

O'Connor, J.E., 2004, The evolving landscape of the Columbia River Gorge - Lewis and Clark and cataclysms on the Columbia: Oregon Historical Quarterly, v. 105, no. 3, p. 390-421.

O'Connor, J.E., and Baker, V.R., 1992, Magnitudes and implications of peak discharges from glacial Lake Missoula: Geological Society of America Bulletin, v. 104, p. 267-279.

O’Connor, J.E., and Benito, G., 2009, Late Pleistocene Missoula floods - 15,000-20,000 calendar years before present from radiocarbon dating [abs]: Geological Society of America Abstracts with Program, v. 41, no. 7, p. 169.

O’Connor, J.E., Cannon, C.M., Mangano, J.F., and Evarts, R.C., 2016, Geologic map of the Vancouver and Orchards quad- 
rangles and parts of the Portland and Mount Tabor quadrangles, Clark County, Washington, and Multnomah County, Oregon: U.S. Geological Survey Scientific Investigations Map 3357, scale 1:24,000, at https://doi.org/10.3133/sim3357.

O’Connor, J.E., Sarna-Wojcicki, A., Wozniak, K.C., Pollette, P.J., and Fleck, R.J., 2001, Origin, extent, and thickness of Quaternary geologic units in the Willamette Valley, Oregon: U.S. Geological Survey Professional Paper 1620, 52 p.

Okada, H., and Bukry, D., 1980, Supplementary modification and introduction of code numbers to the low-latitude coccolith biostratigraphy: Marine Micropaleontology, v. 5, p. 321-325.

Oregon Department of Geology and Mineral Industries, 2009, Mist Gas Field production: State of Oregon Department of Geology and Mineral Industries, accessed March 6, 2017, at https://www.oregongeology.org/mlrr/oilgas-report.htm.

Palmer, S.P., Magsino, S.L., Bilderback, E.L., Poelstra, J.L., Folger, D.S., and Niggemann, R.A., 2007, Liquefaction susceptibility and site class maps of Washington State, by county: Washington Division of Geology and Earth Resources Open File Report 2004-20, 78 plates, various scales, 45 p.

Parsons, T., Trehu, A.M., Luetgert, J.H., Miller, K., Kilbride, F., Wells, R.E., Fisher, M.A., Flueh, E., ten Brink, U.S., and Christiansen, N.I., 1998, A new view into the Cascadia subduction zone and volcanic arc-Implications for earthquake hazards along the Washington margin: Geology, v. 26, p. 199-202.

Personius, S.F., 1995, Late Quaternary stream incision and uplift in the forearc of the Cascadia subduction zone, western Oregon: Journal of Geophysical Research: Solid Earth, v. 100, B10, p. 20193-20210.

Petersen, M.D., Moschetti, M.P., Powers, P.M., Mueller, C.S., Haller, K.M., Frankel, A.D., Zeng, Y., Rezaeian, S., Harmsen, S.C., Boyd, O.S., Field, E.H., Chen, R., Luco, N., Wheeler, R.L., Williams, R.A., Olsen, A.H., and Rukstales, K.S., 2015, Seismic-hazard maps for the conterminous United States, 2014: U.S. Geological Survey Scientific Investigations Map 3325, 6 sheets, scale 1:7,000,000, at https://doi.org/10.3133/sim3325.

Peterson, C.D., Gates, E.B., Minor, R., and Baker, D.L., 2013, Accommodation space controls on the latest Pleistocene and Holocene (16-0 ka) sediment size and bypassing in the Lower Columbia River Valley-A large fluvial-tidal system in Oregon and Washington, USA: Journal of Coastal Research, v. 29, no. 5, p. 1191-1211, at https://doi.org/10.2112/JCOASTRESD-12-00172.1.

Pezzopane, S.K., and Weldon, R.J., II, 1993, Tectonic role of active faulting in central Oregon: Tectonics, v. 12, p. 1140-1169.

Phillips, W.M., 1987a, Geologic map of the Vancouver quadrangle, Washington: Washington Division of Geology and Earth Resources Open-File Report 87-10, scale 1:100,000, pamphlet 27 p.

Phillips, W.M., 1987b, Geologic map of the Mount St. Helens quadrangle, Washington: Washington Division of Geology and Earth Resources Open-File Report 87-4, scale 1:100,000, pamphlet 59 p.

Phillips, W.M., Korosec, M.A., Schasse, H.W., Anderson, J.L., and Hagen, R.A., 1986, K-Ar ages of volcanic rocks in southwest Washington: Isochron West, no. 47, p. 18-24.

Pierson, T.C., Pringle, P.T, and Cameron, K.A., 2010, Magnitude and timing of downstream channel aggradation and degradation in response to a dome-building eruption at Mount Hood, Oregon: Geological Society of America Bulletin, v. 123, p. 2-20.
Pierson, T.C., Scott, W.E., Vallance, J.W., and Pringle, P.T., 2009, Eruption-related lahars and sedimentation response downstream of Mount Hood-Field guide to volcaniclastic deposits along the Sandy River, Oregon, in O'Connor, J.E., Dorsey, R.J., and Madin, I.P., Volcanoes to vineyards - Geologic field trips through the dynamic landscape of the Pacific Northwest: Geological Society of America Field Guide 15, p. 221-236.

Piper, A.M., 1942, Ground-water resources of the Willamette Valley: U.S. Geological Survey Bulletin 890, 194 p.

Popowski, T.A., 1996, Structure, subsurface geology, and neotectonic history of the Tualatin Basin, northwestern Oregon: Corvallis, Oregon State University, unpublished M.S. thesis, 126 p.

Pratt, T.L., Odum, J., Stephenson, W., Williams, R., Dadisman, S., Holmes, M., and Haug, B., 2001, Late Pleistocene and Holocene tectonics of the Portland Basin, Oregon and Washington, from high-resolution seismic profiling: Bulletin of the Seismological Society of America, v. 91, p. 637-650.

Pringle, P.T., Pierson, T.C., and Cameron, K.A., 2002, A circa A.D. 1781 eruption and lahar at Mount Hood, Oregon-Evidence from tree-ring dating and from observations of Lewis and Clark in 1805-6 [abs]: Geological Society of America Annual Meeting Abstracts with programs, v. 34, no. 6, p. 511.

Rapp, E.K., 2005, The Holocene stratigraphy of the Sandy River delta, Oregon: Portland, Oregon, Portland State University, M.S. thesis, $93 \mathrm{p}$.

Rau, W.W., 1981, Pacific Northwest Tertiary benthic foraminiferal biostratigraphic framework-An overview, in Armentrout, J.M., ed., Pacific Northwest Cenozoic Biostratigraphy: Geological Society of America Special Papers, v. 184, p. 67-84.

Rau, W.W., and Johnson, S.Y., 1999, Well stratigraphy and correlations, western Washington and northwestern Oregon: U.S. Geological Survey Geologic Investigations Series I-2621, 31 p.

Reagan, M.K., Ishizuka, O., Stern, R.J., Kelley, K.A., Ohara, Y., Blichert-Toft, J., Bloomer, S.H., Cash, J., Fryer, P., Hanan, B.B., and Hickey-Vargas, R., 2010, Fore-arc basalts and subduction initiation in the Izu-Bonin-Mariana system: Geochemistry, Geophysics, Geosystems, v. 11, no. 3, at https://doi. org/10.1029/2009GC002871.

Redwine, Joanna, Klinger, R.E., Piety, L.A., Wells, R.E., Sherrod, B.L., Howe, J.C., Levinston, R., Hornsby, K., and Niem, A., 2017, Quaternary activity on the Gales Creek Fault, northwest Oregon [abs.]: Geological Society of America Abstracts with Programs, v. 49, no. 6, at http://doi.org/10.1130/ abs/2017AM-306019.

Redwine, Joanna, Klinger, R.E., Wells, R.E., Sherrod, B.L., Mahan, S.A., Piety, L.A., Howe, Julia, Besana-Ostman, Glenda, Levinson, Ryan, Chupik, Colin, Cataldo, Kirstyn, Nicovich, S.R., Angster, S.J., 2019, Evidence for an active Gales Creek Fault - a dynamic duo active deformation confirmation: Geological Society of America Abstracts with Programs, v. 51, no. 4, p. 14.

Reidel, S.P., 2005, A lava flow without a source-The Cohassett Flow and its compositional components, Sentinel Bluffs Member, Columbia River Basalt Group: Journal of Geology, v. 113, p. 1-21.

Reidel, S.P., Camp, V.E., Ross, M.E., Wolff, J.A., Martin, B.S., Tolan, T.L., and Wells, R.E., 2013, The Columbia River flood basalt province: Geological Society of America Special Paper 497, $440 \mathrm{p}$. 
Reidel, S.P., and Tolan, T.L, 2013, The Grande Ronde Basalt, Columbia River Basalt Group, in Reidel, S.P., Camp, V.E., Ross, M.E., Wolff, J.A., Martin, B.S., Tolan, T.L., and Wells, R.E., eds., The Columbia River flood basalt province: Geological Society of America Special Paper 497, p. 117-154.

Reidel, S.P., Tolan, T.L., Hooper, P.R., Beeson, M.H., Fecht, K.R., Bentley, R.D., and Anderson, J.L., 1989, The Grande Ronde Basalt, Columbia River Basalt Group; stratigraphic descriptions and correlations in Washington, Oregon, and Idaho, in Reidel, S.P., and Hooper, P.R., eds., Volcanism and tectonism in the Columbia River flood-basalt province: Geological Society of America Special Paper 239, p. 21-53.

Retallack, G.J., and Burns, S.F., 2016, The effects of soil on the taste of wine: GSA Today, v. 26, no. 5, p. 4-9.

Retallack, G.J., Orr, W.N., Prothero, D.R., Duncan, R.A., Kester, P.R. and Ambers, C.P., 2004, Eocene-Oligocene extinction and paleoclimatic change near Eugene, Oregon: Geological Society of America Bulletin, v. 116, p. 817-839.

Reynolds, N., O’Connor, J.E., Pringle, P.T., Schuster, R.L., Bourdeau, A., 2015, Age of the Bonneville landslide and the drowned forest of the Columbia River, Washington, USA - From wigglematch radiocarbon dating and tree ring analysis [abs.]: Program and abstracts of the 10th Washington Hydrogeology Symposium, p. 71.

Roe, W.P., and Madin, I.P., 2013, 3-D geology and shear-wave velocity models of the Portland, Oregon, metropolitan area: Oregon Department of Geology and Mineral Industries OpenFile Report O-13-12, 48 p., and database.

Rogers, G.C., and Crosson, R.S., 2002, The role of phase changes in the development of forearc basins, in Kirby, S., Wang, K., and Dunlop, S., eds., The Cascadia Subduction Zone and related subduction systems - Seismic structure, intraslab earthquakes and processes, and earthquake hazards: U.S. Geological Survey Open-File Report 02-328, p. 65.

Safley, L.E., 1989, Geology of the Rock Creek-Green Mountain area, southeast Clatsop and northernmost Tillamook counties, northwest Oregon: Corvallis, Oregon, Oregon State University, M.S. thesis, $245 \mathrm{p}$.

Schanz, S.A., and Montgomery, D.R., 2016, Lithologic controls on valley width and strath terrace formation: Geomorphology, v. 258, p. 53-68.

Schlicker, H.G., and Deacon, R.J., 1967, Geology and surficial deposits of the Tualatin Valley region, Oregon: Oregon Department of Geology and Mineral Industries Bulletin 60, 103 p.

Scott, W.E., Pierson, T.C., Schilling, S.P., Costa, J.E., Gardner, C.A., Vallance, J.W., and Major, J.J., 1997, Volcano hazards in the Mount Hood region, Oregon: U.S. Geological Survey OpenFile Report 97-89, 14 p.

Sheriff, S.D., 1984, Paleomagnetic evidence for spatially distributed post-Miocene rotation of western Washington and Oregon: Tectonics, v. 3, no. 3, p. 397-408.

Sherrod, B.L., Brocher, T.M., Weaver, C.S., Bucknam, R.C., Blakely, R.J., Kelsey, H.M., Nelson, A.R., and Haugerud, R., 2004, Holocene fault scarps near Tacoma, Washington, USA: Geology, v. 32, no. 1, p. 9-12.

Sherrod, D.R., and Smith, J.G., 2000, Geologic map of upper Eocene to Holocene volcanic and related rocks of the Cascade Range, Oregon: U.S. Geological Survey Geologic Investiga- tions Series Map I-2569, 2 sheets, scale 1:500,000, at http:// pubs.usgs.gov/imap/i-2569/.

Simenstad, C.A., Burke, J.L., O'Connor, J.E., Cannon, C., Heatwole, D.W., Ramirez, M.F., Waite, I.R., Counihan, T.D., and Jones, K.L., 2011, Columbia River Estuary Ecosystem Classification-Concept and application: U.S. Geological Survey Open-File Report 2011-1228, 54 p.

Smith, G.A., 1993, Missoula flood dynamics and magnitudes inferred from sedimentology of slack-water deposits on the Columbia Plateau, Washington: Geological Society of America Bulletin, v. 105, p. 77-100.

Smith, R.L., and Roe, W.P., 2016, OGDC-6, Oregon geologic data compilation, release 6: Oregon Department of Geology and Mineral Industries, accessed July 16, 2018, at http://www. oregongeology.org/pubs/dds/p-OGDC-6.htm.

Snavely, P.D., Jr., MacLeod, N.S., and Wagner, H.C., 1968, Tholeiitic and alkalic basalts of the Eocene Siletz River Volcanics: American Journal of Science, v. 266, p. 454- 481.

Snavely, P.D., Jr., MacLeod, N.S., and Wagner, H.C., 1973, Miocene tholeiitic basalts of coastal Oregon and Washington and their relations to coeval basalts of the Columbia Plateau: Geological Society of America Bulletin, v. 84, p. 387-424.

Stanley, W.D., Johnson, S.Y., Qamar, A.I., Weaver, C.S., and Williams, J.M., 1996, Tectonics and seismicity of the southern Washington Cascade Range: Bulletin of the Seismological Society of America, v. 86, no. 1A, p. 1-18.

Swanson, D.A., Wright, T.L., Hooper, P.R., and Bentley, R.D., 1979, Revisions in stratigraphic nomenclature of the Columbia River Basalt Group: U.S. Geological Survey Bulletin 1457-G, 59 p.

Swanson, R.D., 1986, A stratigraphic-geochemical study of the Troutdale Formation and Sandy River Mudstone in the Portland Basin and lower Columbia River Gorge: Portland, Oregon, Portland State University, M.S. thesis, 103 p.

Swanson, R.D., 1988, A stratigraphic-geochemical study of the Troutdale Formation and Sandy River Mudstone in the Portland Basin and lower Columbia River Gorge [abs.]: Oregon Geology, v. 50, no. 5-6, p. 66.

Swanson, R.D., McFarland, W.D., Gonthier, J.B., and Wilkinson, J.M., 1993, A description of hydrogeologic units in the Portland Basin, Oregon and Washington: U.S. Geological Survey WaterResources Investigations Report 90-4196, 56 p., scale 1:100,000.

Thomas, G.C., Crosson, R.S., Carver, D.L., and Yelin, T.S., 1996, The 25 March 1993 Scotts Mills, Oregon, earthquake and aftershock sequence; spatial distribution, focal mechanisms, and the Mount Angel fault: Bulletin of the Seismological Society of America, v. 86, no. 4, p. 925-935.

Tolan, T.L., 1982, The stratigraphic relationships of the Columbia River Basalt Group in the lower Columbia River Gorge of Oregon and Washington: Portland, Oregon, Portland State University, M.S. thesis, $151 \mathrm{p}$.

Tolan T.L., and Beeson, M.H., 1984, Intracanyon flows of the Columbia River Basalt Group in the lower Columbia River Gorge and their relationship to the Troutdale Formation: Geological Society of America Bulletin, v. 95, p. 463-477.

Tolan, T.L., Martin, B.S., Riedel, S.P., Anderson, J.L., Lindsey, K.A., and Burt, W., 2009, An introduction to stratigraphy, structural geology, and hydrogeology of the Columbia River FloodBasalt Province-A primer for the GSA Columbia River Basalt 
Group field trips, in O’Connor, J.E., Dorsey, R.J., and Madin, I.P., eds., Volcanoes to vineyards - Geologic field trips through the dynamic landscape of the Pacific Northwest: Geological Society of America Field Guide 15, p. 599-643.

Tolan, T.L., Reidel, S.P., Beeson, M.H., Anderson, J.L., Fecht, K.R., and Swanson, D.A., 1989, Revisions to the estimates of the areal extent and volume of the Columbia River Basalt Group, in Reidel, S.P., and Hooper, P.R., eds., Volcanism and tectonism in the Columbia River flood-basalt province: Geological Society of America Special Paper 239, p. 1-20.

Treasher, R.C., 1942, Geologic history of the Portland area: Oregon Department of Geology and Mineral Industries Short Paper 7, $17 \mathrm{p}$.

Trimble, D.E., 1957, Geology of the Portland quadrangle, OregonWashington: U.S. Geological Survey Geologic Quadrangle Map GQ-104, scale 1:62,500.

Trimble, D.E., 1963, Geology of Portland, Oregon, and adjacent areas: U.S. Geological Survey Bulletin 1119, 119 p., scale $1: 62,500$.

U.S. Geological Survey, Quaternary fault and fold database of the United States: accessed July 15, 2018, at http://earthquake.usgs. gov/hazards/qfaults/.

U.S. Geological Survey National Cooperative Geologic Mapping Program, in press: GeMS (Geologic Map Schema)—A standard format for digital publication of geologic maps: U.S. Geological Survey Techniques and Methods, Book 11, Chap. B10.

Van Atta, R.O., 1971, Stratigraphic relationships of the Cowlitz Formation, upper Nehalem River Basin, northwest Oregon: The Ore Bin, v. 33, no. 9, p. 165-181.

Van Atta, R.O., and Kelty, K.B., 1985, Scappoose Formation, Columbia County, Oregon; evidence of age and relation to Columbia River Basalt Group: American Association of Petroleum Geologists Bulletin, v. 69, no. 5, p. 688-698.

Vogel, M.S., 2005, Quaternary geology of the lower Lewis River valley, Washington - Influence of volcanogenic sedimentation following Mount St. Helens eruptions: Pullman, Washington State University, M.S. thesis, 65 p.

Waitt, R.B., Jr., 1980, About 40 last-glacial Lake Missoula jökulhlaups through southern Washington: Journal of Geology, v. 88, p. 653-679.

Waitt, R.B., Jr., 1985, Case for periodic, colossal jökulhlaups from Pleistocene glacial Lake Missoula: Geological Society of America, v. 96, p. 1271-1286.

Waitt, R.B., Jr., 1994, Scores of gigantic, successively smaller Lake Missoula floods through channeled scabland and Columbia valley, in Swanson, D.A., and Haugerud, R.A., eds., Geologic field trips in the Pacific Northwest: Seattle, University of Washington Department of Geological Sciences, p. 1K1-1K88.

Waitt, R.B., Jr., 1996, Numerous colossal Missoula floods through Columbia Gorge and Portland-Vancouver Basin [abs.]: Geological Society of America Abstracts with Program, v. 28, no. 5, p. 120-121.

Walcott, D., 1993, Neogene tectonics and kinematics of western North America: Tectonics, v. 12, no. 2, p. 326-333.

Walker, G.W., and MacLeod, N.S., 1991, Geologic map of Oregon: U.S. Geological Survey, 2 oversize sheets, scale 1:500,000.

Walsh, K., Peterson, G.L., Beeson, M.H., Wells, R.E., Fleck, R.J., Evarts, R.C., Duvall, A., Blakely, R.J., and Burns, S., 2011, A tunnel runs through it - An inside view of the Tualatin Mountains, Oregon: U.S. Geological Survey Scientific Investigations Map 3144, one oversize sheet with text.

Walsh, T.J., Korosec, M.A., Phillips, W.M., Logan, R.L., and Schasse, H.W., 1987, Geologic map of Washington — southwest quadrant: Washington Division of Geology and Earth Resources Map GM-34, scale 1:250,000.

Wampler, P.J., 2004, Contrasting geomorphic responses to climatic, anthropogenic, and fluvial change across modern to millennial time scales, Clackamas River, Oregon: Corvallis, Oregon State University, Ph.D. dissertation, 398 p.

Wang, K., Wells, R., Mazzotti, S., Hyndman, R.D., and Sagiya, T., 2003, A revised dislocation model of interseismic deformation of the Cascadia Subduction Zone: Journal of Geophysical Research, Solid Earth, v. 108, no. B1, https://doi. org/10.1029/2001JB001227.

Warren, W.C., Grivetti, R.M., and Norbisrath, H., 1945, Geology of northwestern Oregon, west of the Willamette River and north of latitude 45 $15^{\prime}$ : U.S. Geological Survey Oil and Gas Investigations Preliminary Map 42, scale 1:143,000.

Warren, W.C., and Norbisrath, H., 1946, Stratigraphy of upper Nehalem River Basin, northwestern Oregon: American Association of Petroleum Geologists Bulletin, v. 30, p. 213-237.

Waters, A.C., 1973, The Columbia River Gorge - Basalt stratigraphy, ancient lava dams, and landslide dams, in Beaulieu, J.D., ed., Geologic field trips in northern Oregon and southern Washington: Oregon Department of Geology and Mineral Industries Bulletin 77, p. 133-162.

Wells, R., 2006, Oregon geology_Parent of the soil, foundation for the vine: U.S. Geological Survey Open-File Report 20061069, at http://pubs.usgs.gov/of/2006/1069/.

Wells, R.E., Blakely, R.J., and Bemis, Sean, 2020, Northward migration of the Oregon forearc on the Gales Creek Fault, northwest Oregon: Geosphere, v. 16, 25 p., https://doi. org/10.1130/GES02177.1.

Wells, R.E., Bukry, D., Friedman, R., Pyle, D., Duncan, R., Haeussler, P., and Wooden, J., 2014, Geologic history of Siletzia, a large igneous province in the Oregon and Washington Coast Range - Correlation to the geomagnetic polarity time scale and implications for a long-lived Yellowstone hotspot: Geosphere, v. 10, no. 4, 28 p., at https://doi.org/10.1130/GES01018.1.

Wells, R.E., and Coe, R.S., 1985, Paleomagnetism and geology of Eocene volcanic rocks of southwest Washington, implications for mechanisms of tectonic rotation: Journal of Geophysical Research, Solid Earth, v. 90, no. B2, p. 1925-1947.

Wells, R.E., Haugerud, R.A., Niem, A.R., Niem, W.A., Ma, L., Madin, I., and Evarts, R.C., 2018, New geologic mapping of the northwestern Willamette Valley, Oregon, and its American Viticultural Areas (AVAs) - A foundation for understanding their terroir: U.S. Geological Survey Open-File Report 2018-1044, 1 oversized sheet.

Wells, R.E., Jayko, A.S., Niem, A.R., Black, G., Wiley, T., Baldwin, E., Molenaar, K.M., Wheeler, K.L., DuRoss, C.B., and Givler, R.W., 2000, Geologic map and database of the Roseburg 30 ' x 60' quadrangle, Douglas and Coos counties, Oregon: U.S. Geological Survey Open-File Report 00-376, 2 plates, 55 p.

Wells, R.E., Niem, A.R., Evarts, R.C., and Hagstrum, J.T., 2009, The Columbia River Basalt Group from the gorge to 
the sea, in O'Connor, J.E., Dorsey, R.J., and Madin, I.P., eds., Volcanoes to vineyards - Geologic field trips through the dynamic landscape of the Pacific Northwest: Geological Society of America Field Guide 15, p. 737-774, at https://doi. org/10.1130/2009.fld015(32).

Wells, R.E., Niem, A.R., MacLeod, N.S., Snavely, P.D., Jr., and Niem, W.A., 1983, Preliminary geologic map of the west half of the Vancouver (Washington-Oregon) $1^{\circ} \times 2^{\circ}$ quadrangle, Oregon: U.S. Geological Survey Open File Report 83-591, 1 sheet, scale 1:250,000, at https://doi.org/10.3133/ofr83591.

Wells, R.E., Simpson, R.W., Bentley, R.D., Beeson, M.H., Mangan, M.T., and Wright, T.L., 1989, Correlation of Miocene flows of the Columbia River Basalt Group from the central Columbia River Plateau to the coast of Oregon and Washington, in Reidel, S.P., and Hooper, P.R., eds., Volcanism and tectonism in the Columbia River flood-basalt province: Geological Society of America Special Paper 239, p. 113-129.

Wells, R.E., Snavely, P.D., Jr., Macleod, N.S., Kelly, M.M., Parker, M.J., Fenton, J., and Felger, T., 1995, Geologic map of the Tillamook Highlands, northwest Oregon Coast Range - a digital database: U.S. Geological Survey Open-File Report 95-670, at http://pubs.usgs.gov/of/1995/of95-670/.

Wells, R.E., Weaver, C.S., and Blakely, R.J., 1998, Fore-arc migration in Cascadia and its neotectonic significance: Geology, v. 26, p. 759-762.

West, W.B., Brabb, E.E., Malmborg, W.T., and Parker, J.M., 2009, Digital coordinates and age for 3,869 foraminifer samples collected by Chevron petroleum geologists in Washington and Oregon: U.S. Geological Survey Open-File Report 2009-1185, 7 p., 2 databases.

Wheeler, K.L., Wells, R.E., Minervini, J.M., and Block, J.L., 2009, Geologic map of the Carlton quadrangle, Yamhill County, Oregon: U.S. Geological Survey Open-File Report 2009-1172, scale 1:24,000, and database, at http://pubs.usgs. gov/of/2009/1172/.

Wilkinson, W.D., Lowry, W.D., and Baldwin, E.M., 1945, Geologic map of the Saint Helens quadrangle, Oregon and Washington: Oregon Department of Geology and Mineral Industries Map 9.

Wilkinson, W.D., Lowry, W.D., and Baldwin, E.M., 1946, Geology of the Saint Helens quadrangle, Oregon: Oregon Depart- ment of Geology and Mineral Industries Bulletin 31, 39 p., scale $1: 62,500$.

Wilson, D.S., 1993, Confidence intervals for motion and deformation of the Juan de Fuca plate: Journal of Geophysical Research, Solid Earth, v. 98, no. B9, p. 16053-16071.

Wilson, D.C., 1997, Post-middle Miocene geologic history of the Tualatin Basin, Oregon, with hydrologic implications: Portland, Oregon, Portland State University, unpublished Ph.D. dissertation, $321 \mathrm{p}$.

Wilson, D.C., 1998, Post-middle Miocene geologic evolution of the Tualatin Basin, Oregon: Oregon Geology, v. 60, no. 5, p. 99-116.

Wilson, D., 2000, Provenance of the Hillsboro Formation; implications for the structural evolution and fluvial events in the Tualatin Basin, northwest Oregon: Journal of Sedimentary Research, v. 70, p. 117-126.

Wilson, D.C., 2003, Hydrogeology and water resource potential of Neogene sediments in the Tualatin Basin and comparison with the neighboring Portland Basin, northwest Oregon: Environmental and Engineering Geoscience, v. 9, no. 4, p. 327-338.

Wong, I.G., Hemphill-Haley, A., Liberty, L.M., and Madin, I.P., 2001, The Portland Hills Fault - An earthquake generator or just another old fault?: Oregon Geology, v. 63, p. 39-50.

Wong, I.G., Silva, W., Bott, J., Wright, D., Thomas, P., Gregor, N., Li, S., Mabey, M., Sojouner, A., and Wang, Y., 2000, Earthquake scenario and probabilistic ground shaking maps for Portland, Oregon, area: Oregon Department of Geology and Mineral Industries MS-16, 16 p., 11 maps, scale 1:62,500.

Woodward, D.G., Gannett, M.W., and Vaccaro, J. J., 1998, Hydrogeologic framework of the Willamette Lowland aquifer system, Oregon and Washington: U.S. Geological Survey Professional Paper 1424-B, 82 p.

Yeats, R.S., Graven, E.P., Werner, K.S., Goldfinger, C., and Popowski, T.A., 1996, Tectonics of the Willamette Valley, Oregon, in Assessing earthquake hazards and reducing risk in the Pacific Northwest: U.S. Geological Survey Professional Paper 1560, p. 183-222.

Yelin, T.S., and Patton, H.J., 1991, Seismotectonics of the Portland, Oregon, region: Seismological Society of America Bulletin, v. 81, p. 109-130. 
Table 1. Sources of map data in SIM3443.gdb, Tualatin.gdb, and OtherSources.gdb.

[CRBG, Columbia River Basalt Group; USGS, U.S. Geological Survey]

\begin{tabular}{|c|c|}
\hline SourcelD value & Explanation \\
\hline \multicolumn{2}{|r|}{ New and unpublished map data present only in SIM3443.gdb } \\
\hline Dibblee & $\begin{array}{l}\text { Orientation data from unpublished field sheets by Tom Dibblee, 1945, Chapman and Trenhom quadrangles. From } \\
\text { USGS files of Parke Snavely, Jr. }\end{array}$ \\
\hline $\mathrm{H} \& \mathrm{E}$ & $\begin{array}{l}\text { R. Haugerud and R. Evarts, new interpretation for this compilation. Reinterpretation at the west edge of the Sauvie } \\
\text { Island quadrangle, southeast corner of the Dixie Mountain quadrangle, and northwest corner of the Linnton quad- } \\
\text { rangle. }\end{array}$ \\
\hline Niem & $\begin{array}{l}\text { A. Niem and W. Niem, geologic map of Bacona, Baker Point, Birkenfield, Clear Creek, Pittsburg, and Vernonia } \\
\text { quadrangles. Compiled and simplified by Haugerud from unpublished 1:24,000-scale quadrangle maps. Authors } \\
\text { of these quadrangle maps: Bacona-Niem, A.R., Niem, W.A., Houston, R.A., and Hanson, W.B.; Baker Point- } \\
\text { Niem, A.R. and Niem, W.A.; Birkenfeld-Niem, A.R., Niem, W.A., and Hinkle, Jason; Clear Creek-Niem, A.R., } \\
\text { Hanson, W.B., Hinkle, Jason, and Niem, W.A.; Pittsburg-Niem, A.R., Niem, W.A., Houston, R.A., Hanson, } \\
\text { W.B., Moore, E.J., and Hinkle, Jason; Vernonia-Niem, A.R., Niem, W.A., Hanson, W.B., McKnight, B.K., } \\
\text { Hinkle, Jason, and Moore, E.J. Also sample locations and previously unpublished whole-rock chemical analyses. }\end{array}$ \\
\hline Sawlan & Sample locations from M. Sawlan field notes and previously unpublished whole-rock chemical analyses. \\
\hline W\&H & $\begin{array}{l}\text { R. Wells and R. Haugerud, new interpretations for this compilation. Includes minor to extensive revisions at map } \\
\text { boundaries, bedrock contacts drawn where small areas of unconsolidated material were omitted, and local exten- } \\
\text { sive reinterpretation. Includes an interpretation of the geology of the Chapman and Trenholm quadrangles based } \\
\text { on unpublished field notes by A. Niem, M. Sawlan, and R. Wells and published mapping of Wilkinson, W.D., } \\
\text { Lowry, W.D., and Baldwin, E.M. }\end{array}$ \\
\hline USGS & $\begin{array}{l}\text { Tualatin valley top-of-CRBG contours compiled by Matt Anders, USGS, from Doyle Wilson's Ph.D. (Wilson, 1997) } \\
\text { and selected post-1997 well data. }\end{array}$ \\
\hline Wells & Sample locations from R. Wells field notes and previously unpublished whole-rock chemical analyses. \\
\hline \multicolumn{2}{|r|}{ Published map data present only in SIM3443.gdb } \\
\hline NHD & $\begin{array}{l}\text { National Hydrographic Dataset, geodatabase best resolution for Oregon, file NHDH_OR_931v220.zip. Downloaded } \\
\text { from nhdftp.usgs.gov on August 1, } 2015 \text {. }\end{array}$ \\
\hline PP1560 & Subsurface fault locations from Yeats and others (1996). \\
\hline SIR 2005-5168 & Conlon and others (2005). Top-of-basalt contours hand digitized from georegistered image of figure 9. \\
\hline Vogel & Contacts from Vogel (2005), compiled and modified by C. Cannon (USGS), J. O'Connor, and R. Haugerud. \\
\hline WRI 90-4196 & Swanson and others (1993). Top-of-basalt contours hand digitized from georegistered image of plate 3. \\
\hline \multicolumn{2}{|r|}{ New map data that are present in more complete form in Tualatin.gdb } \\
\hline Tualatin & $\begin{array}{l}\text { 1:24,000-scale geologic maps of the Meacham Corner, Gales Creek, Forest Grove, Gaston, Laurelwood, Scholls, } \\
\text { Beaverton, Dundee, and Newberg quadrangles in the Tualatin Valley area. Mapped by Wells and digitized by K. } \\
\text { Wheeler, A. Duvall, R. Givler, C. DuRoss, and P. Dinterman. Translated to GeMS database schema by Haugerud } \\
\text { and compiled to a single block by R. Wells and R. Haugerud. }\end{array}$ \\
\hline \multicolumn{2}{|r|}{ Published and unpublished map data that are present in uncompiled form in OtherSources.gdb } \\
\hline Amboy & Evarts (2005) \\
\hline Ariel & Evarts (2004a) \\
\hline BattleGround & Unpublished revision by R. Evarts of Howard (2002) \\
\hline Buxton & Dinterman and Duval (2009) \\
\hline Camas & Evarts and O'Connor (2008) \\
\hline Canby & Unpublished USGS contract geologic mapping at 1:24,000 scale by M.H. Beeson and T.L. Tolan, 2001. \\
\hline Carlton & Wheeler and others (2009) \\
\hline Deer Island & Evarts (2002) \\
\hline DOGAMI_O-12-02 & Ma and others (2012) \\
\hline DOGAMI O-13-12 & Roe and Madin (2013). Some wells in TopCRBG_ControlPoints \\
\hline LacamasCreek & Evarts (2006b) \\
\hline Ma2015 & Unpublished revision by L. Ma to correct minor GIS topology errors in Ma and others (2012). \\
\hline OGDC-5 & Ma and others (2009) \\
\hline
\end{tabular}


Table 1. Sources of map data in SIM3443.gdb, Tualatin.gdb, and OtherSources.gdb—Continued

\begin{tabular}{lc}
\hline \multicolumn{1}{c}{ SourcelD value } & \multicolumn{1}{c}{ Explanation } \\
\hline \multicolumn{1}{l}{ Pidgefield } & Published and unpublished map data that are present in uncompiled form in OtherSources.gdb-Continued \\
SauvieIsland & Evarts and others (2016) \\
Sherwood & Unpublished 1:24,000-scale geologic mapping by D. Sherrod, USGS, 2004-2005. Also includes sample locations \\
& and tables of whole-rock chemical analyses. \\
SI_V_O & Unpublished preliminary version of database for Evarts and others (2016) and O'Connor and others (2016). \\
StHelens & Evarts (2004c) \\
Tillamook & Wells and others (1995) \\
Washougal & Evarts and others (2013) \\
Woodland & Evarts (2004b) \\
Yacolt & Evarts (2006a) \\
\hline
\end{tabular}



WMin mil

mis

mis

尚

on

के

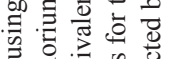

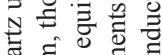

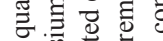

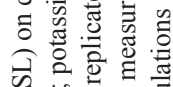

仓

0.500.

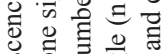

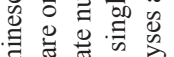

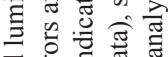

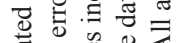

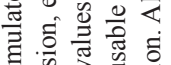

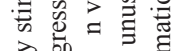

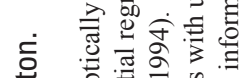

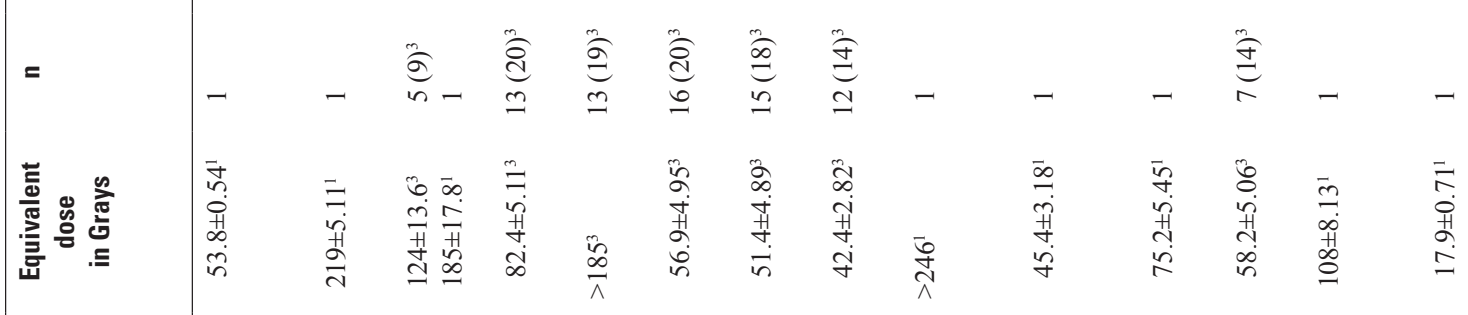

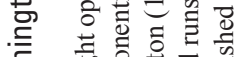

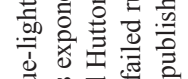

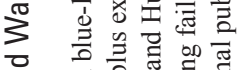

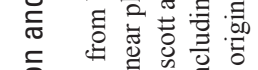

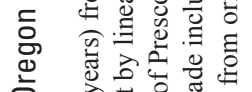

व

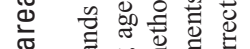

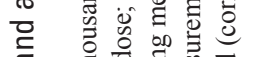

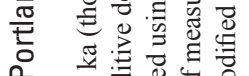

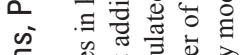

立

苛产

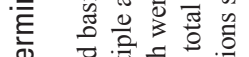

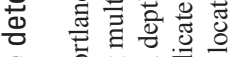

范

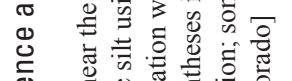

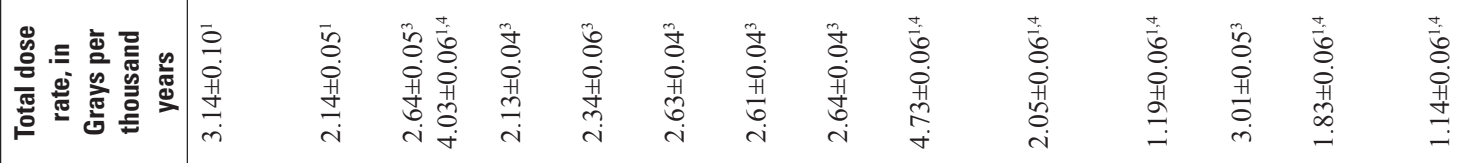

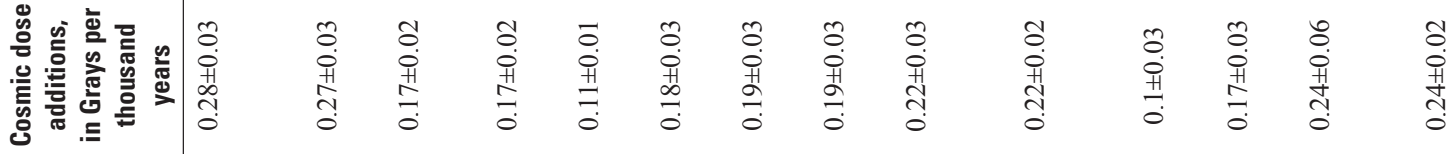

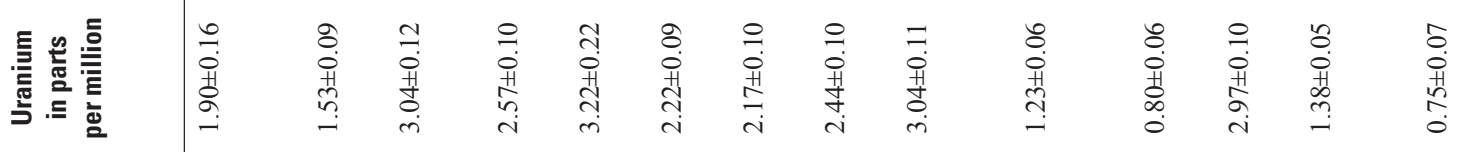

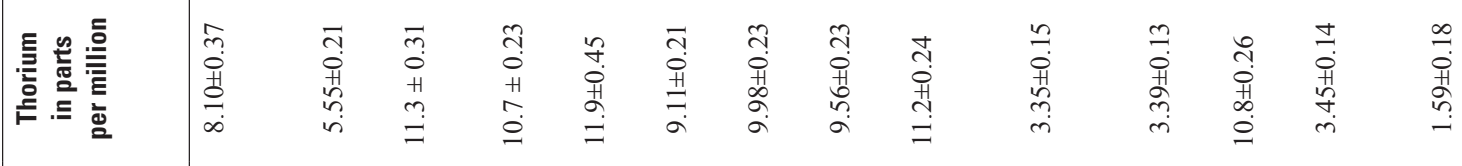

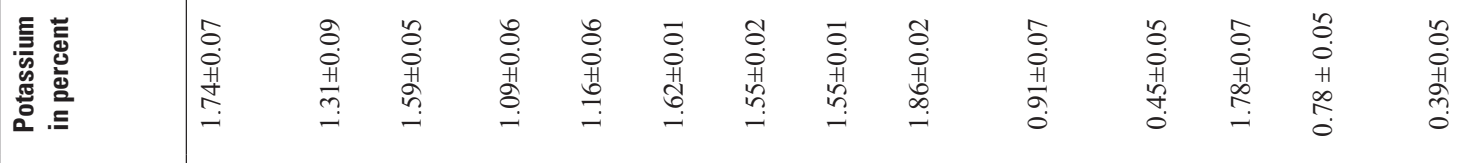

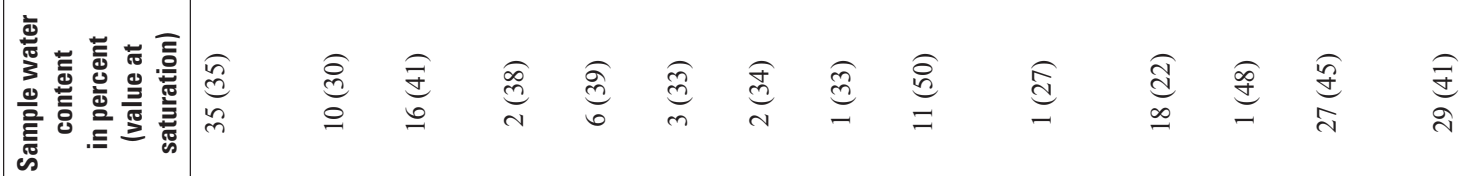

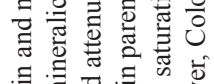

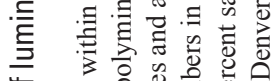

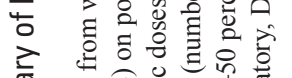

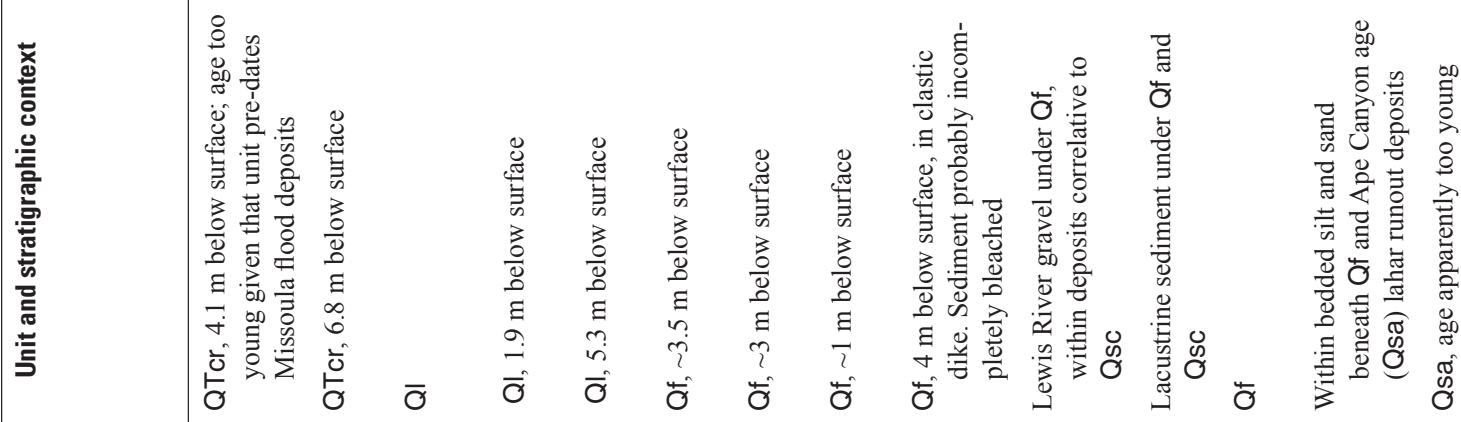

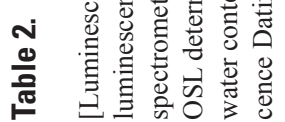

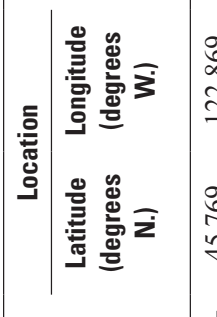

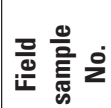

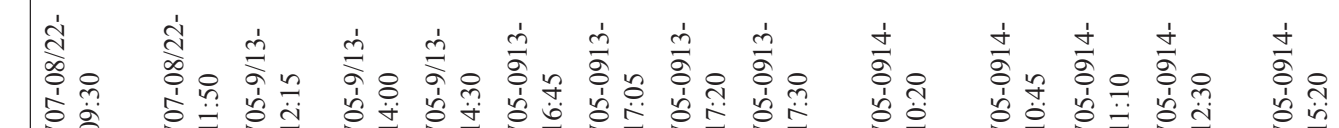

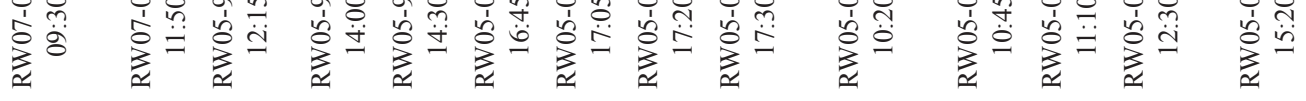




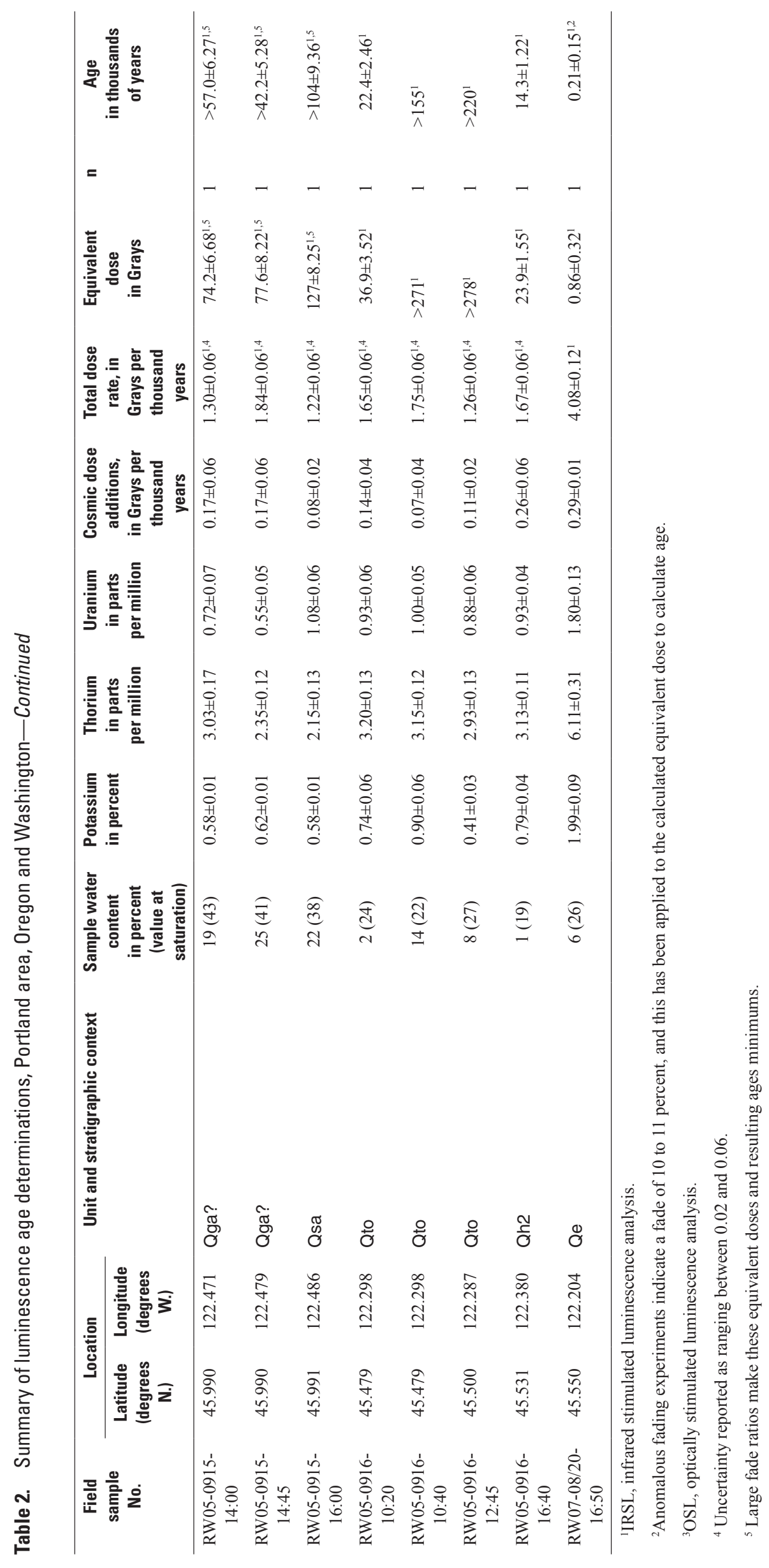

